\title{
LA PASTORAL INDÍGENA DEL SIGLO XXI EN EL SUR DE MÍXICO
}

\section{MISIONEROS, SOGIEDAD GIVIL Y GOBERNANZA}

Jorge Valtierra Zamudio 


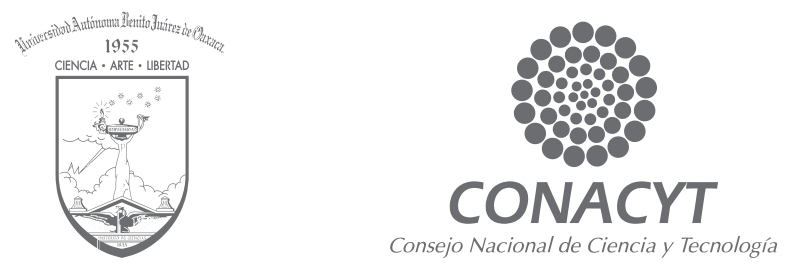


\section{LA PASTORAL INDÍGENA DEL SIGLO XXI EN EL SUR DE MÉXICO}

MISIONEROS, SOGIEDAD GIVIL Y GOBERNANZA

Jorge Valtierra Zamudio 
La pastoral indígena del siglo XXI en el sur de México. Misioneros, sociedad civil y gobernanza (C) 2019

Universidad Autónoma "Benito Juárez" de Oaxaca

Av. Universidad s/n, col. Cinco Señores, C.P. 68120

Oaxaca de Juárez, Oaxaca, México.

http://www.uabjo.mx

Todos los derechos reservados. Este libro está protegido por los derechos de autor. Ninguna parte puede ser reproducida, almacenada en un sistema de recuperación o transmitida en cualquier forma o por cualquier medio (electrónico, mecánico, fotocopia, grabación u otros) sin autorización previa de la entidad editora. La infracción de dichos derechos puede constituir un delito contra la propiedad intelectual.

Primera edición, 2019

ISBN versión impresa: 978-607-9061-81-4

ISBN versión electrónica: 978-607-9061-82-1

Esta obra fue dictaminada positivamente por pares ciegos externos, según los requerimientos y procedimientos del Comité Editorial de la Universidad Autónoma "Benito Juárez" de Oaxaca.

Imagen de portada: Reyes Hernández Gruz

Guidado editorial y creación del concepto gráfico:

Servicios editoriales Scriptus

www.scriptus.com.mx

Impreso en México/Printed in Mexico

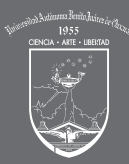




\section{ÍNDICE}

INTRODUGGIÓN

\section{GAPÍTULO 1}

\section{Los constructores Del ReINo De Dios EN MÉXICO:}

LA TRANSFORMAGIÓN DE LOS “MISIONEROS” EN LA IGLESIA

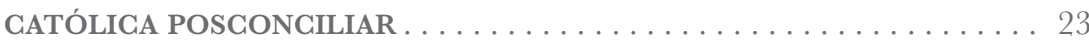

Origen y contexto de la teología de la liberación......... 31

La Iglesia católica en el contexto de la Guerra Fría . . . . . . . . . . 38

La reforma eclesiástica: el Concilio Vaticano II y

sus consecuencias......................... 41

Conferencia General del Episcopado Latinoamericano

(Medellín 1968) ............................... 44

La emergencia de la pastoral indígena en México:

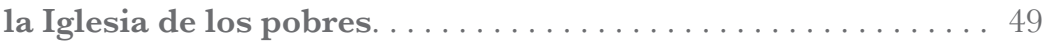

La pastoral indígena en el sureste mexicano: el caso de Chiapas ... 51

La teología de la inculturación o encarnación

del evangelio. . . . . . . . . . . . . . . . . . . 61

Inculturarse en la praxis $\ldots \ldots \ldots \ldots \ldots \ldots \ldots \ldots . \ldots 6$

\section{GAPÍTULO 2}

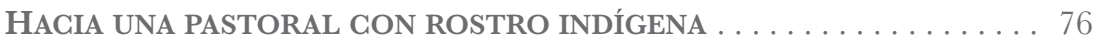

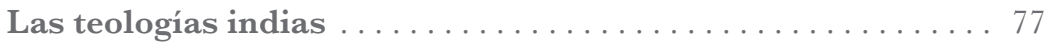


Teología india india y teología india cristiana . . . . . . . . . . . 89

La teología india cristiana a partir de un

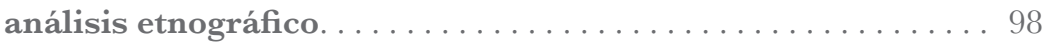

El jbankilal y la teología india cristiana: reinterpretación

religiosa en Rizo de Oro, Chiapas. . . . . . . . . . . . . . . . . . . 102

La acción pastoral en la teología india cristiana,

¿una forma de adoctrinamiento?...................... 112

\section{GAPÍTULO 3}

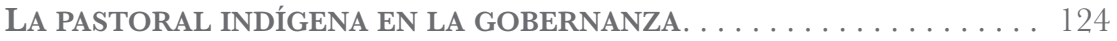

Ecoteología y sostenibilidad: una propuesta de

gobernanza ambiental ...................... 134

Educación, revolución y ecología desde la Iglesia católica

en el sur de México . ........................... 147

La comunicación intercultural en el proyecto de

la pastoral indígena ...................... 156

Interculturalidad, identidad y alteridad. . . . . . . . . . . . 160

Comunicación intercultural. . . . . . . . . . . . . . . . . 167

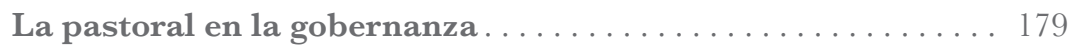

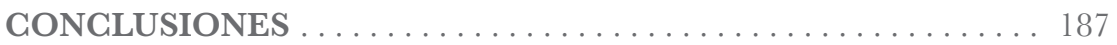

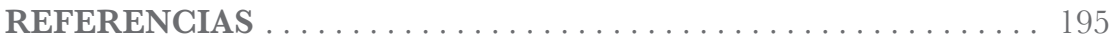




\section{AGRADECIMIENTOS}

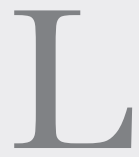

a escritura de esta obra es producto de una investigación desarrollada desde mi primer encuentro con el sur-sureste mexicano, tanto bibliográficamente como in situ, desde el año 2007, y en Guatemala desde 2008. Los vínculos que tiempo atrás había con la congregación de los Hermanos Maristas de la Enseñanza y el posterior contacto que se estableció con otros agentes de pastoral, colegas, maestros y catequistas indígenas, llevó a tejer un escenario complejo de relaciones que tomó mucho tiempo discernir y que los dos trabajos de tesis (maestría y doctorado) fueron insuficientes para desvelar.

En la Escuela Nacional de Conservación, Restauración y Museografía del INAH, hasta la Facultad de Derecho de la Universidad La Salle, México, instituciones en donde me he desarrollado profesionalmente, tuve un intercambio muy interesante de opiniones y posturas acerca de la cultura, la patrimonialidad y la gobernanza, que fue indispensable para empezar a madurar ideas sobre este tema de investigación.

La interminable lista de personas que formaron parte $-\mathrm{y}$ lo seguirán haciendo- de esta investigación tiene un gran valor, pues aportaron testimonios sin los cuales no podría desarrollarse un trabajo de esta índole. No se trata sólo de los conceptos de interculturalidad, gobernanza, inculturación, entre otros, sino de la vida y experiencia de mucha gente que puso los fundamentos para aplicar la teoría, pues, como me repetía incansablemente mi gran colega y 
amigo José Antonio Flores Farfán, no se debe "anteponer la teoría a la práctica".

Agradezco profundamente a quienes me recibieron en sus comunidades, a los pueblos tojolabales, chujes, en especial a Yakín, Elsa y Dori, de Nuevo Porvenir, con quienes compartí vivencias muy importantes después de ocho años de ausencia en esa zona de Chiapas. Agradezco también a Salvador Galindo y a Marcos Sandoval por el intercambio de ideas y debates, camino a Santa María Ixcatlán y Santa Catarina Ocotlán, en Oaxaca.

Agradezco a figuras inspiradoras en mi formación profesional, como el Dr. Jesús Ruvalcaba Mercado, Aída Hernández Castillo, José Antonio Flores Farfán (It's all for fun.); así como a colegas entrañables, entre ellos Antonio Hernández Curiel, Guillermo Pereyra, Estíbaliz Guzmán y Guadalupe de la Torre, de la ENCRYM, y, por supuesto, a Cutberto Hernández Legorreta, Elena Pompa Dávalos, Gabriela Cabestany Ruiz, Andrés Camino de Villa y a los amigos del GIDi+ de Estudios sobre Justicia Social, Pobreza y Desigualdad, de la Universidad La Salle.

Hago mención especial de la Dra. Lorena Córdova, quien formó parte de este proyecto, por su apoyo y retroalimentación, así como por haberme considerado para formar parte del proyecto de investigación "Fronteras de la Ciencia" de Conacyt.

Es importante señalar que este proyecto no hubiera sido posible sin el apoyo de la Universidad Autónoma "BenitoJuárez" de Oaxaca y la Dra. Gisela Fuentes Mascorro, directora de Investigación y de la editorial de esta casa de estudios, quien me brindó todas las facilidades para llevar a cabo este producto académico, así como al Consejo Nacional de Ciencia y Tecnología, que través del Proyecto No. 3035: "Revitalización de lenguas y culturas 
fronterizas y en riesgo de desaparición: documentación, planificación y colaboración comunitaria", de la Convocatoria Fronteras de la Ciencia 2016, fue posible financiar viajes y obtener material bibliográfico y etnográfico para actualizar datos y desarrollar nuevas aportaciones al tema.

Asimismo, agradezco el apoyo del Mtro. José María Aramburu Alonso, de la Facultad de Derecho de la Universidad La Salle y el Departamento de Posgrado e Investigación, a través del Grupo de Investigación, Desarrollo e Innovación: "Aproximación a los nuevos paradigmas de la sociedad internacional: regiones, actores, estructuras e instituciones", por las facilidades otorgadas para enfocarme en mi investigación.

Ciudad de México, 15 de octubre de 2019 


\section{INTRODUCCIÓN}

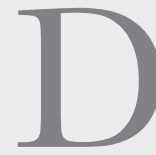

urante la segunda mitad del siglo XX, América Latina se caracterizó por una serie de cambios a nivel mundial, entre ellos diversas coyunturas sociohistóricas marcadas por la tensión entre el Estado y la sociedad civil. Tal es el caso de los movimientos de guerrillas inspirados en la Revolución cubana y su ideología que podían observarse en contextos como el de Venezuela y Guatemala.

También fue visible un conjunto de transformaciones ideológico-metodológicas en distintas disciplinas sociales, como en Educación, Sociología, Antropología Social, Historia, entre otras, más vinculadas con las tendencias también revolucionarias a favor de los pobres, en contra de la modernidad y de la dependencia de modelos económicos y políticos de América hacia Estados Unidos y Europa occidental, y un gran impacto en distintos organismos internacionales, como la Iglesia católica, lo que se evidencia con la reforma del Concilio Vaticano II (1962-1965) y la Encíclica Populorum Progressio (1967), con la idea de actualizarse (aggiornamento) y ser sensible a la realidad del mundo.

La reforma conciliar de Vaticano II tuvo un gran efecto tanto al interior como al exterior de la Iglesia católica a nivel global. Se trató de un cambio que le daba importancia a la diversidad cultural y a la necesidad de que la Iglesia se adaptara a las diferentes sociedades, razón por la que modifica la forma de realizar el rito y de vernaculizarlo sin afectar el dogma, 
y de otorgar más peso al laico para que fuera más partícipe de la labor eclesiástica.

Entre muchos otros aspectos, con esta reforma se promovió una suerte de diálogo con las diferentes culturas, entendiendo por cultura desde el Concilio Vaticano II lo que se aprecia en el documento Gaudium et Spes:

Todo aquello con lo que el hombre afina y desarrolla sus innumerables cualidades espirituales y corporales; procura someter el mismo orbe terrestre con su conocimiento y trabajo; hace más humana la vida social, tanto en la familia como en toda la sociedad civil, mediante el progreso de las costumbres e instituciones; finalmente, a través del tiempo, expresa, comunica y conserva en sus obras grandes experiencias espirituales y aspiraciones para que sirvan de provecho a muchos, e incluso a todo el género humano (Concilio Vaticano II, s/f, p. 53).

El diálogo con las culturas también se refiere a la necesidad de establecer una Iglesia que debía generar un acercamiento ecuménico e interreligioso y, entonces, comenzar a romper con el eurocentrismo que por siglos el catolicismo ha abrazado. Pero en muchos casos esto provocó polémica y mucha tensión al interior de la organización eclesiástica, entre las alas más ortodoxas o conservadoras y las posiciones de izquierda que, inspiradas, movían conciencias entre los miembros jóvenes de la Iglesia, sobre todo en aquellos que habían tenido contacto con sociedades desfavorecidas en África y América Latina.

En este ambiente que se produjo a partir de dicha reforma y la idea de adaptarse a los otros y descentrarse se percibía un rechazo 
por parte de los grupos más conservadores hacia los integrantes más jóvenes y los más proclives al Concilio Vaticano II, bajo el argumento de que la Iglesia no debía involucrase en asuntos políticos. Lo anterior significa que, además de la tendencia a lo largo del siglo XIX europeo de la separación de la Iglesia y el Estado - en especial con el liberalismo que pregonaba la Revolución francesa de 1789 en adelante y que influyó también en el contexto latinoamericano decimonónico-, había un posicionamiento claro de una Iglesia que debía concentrarse en los asuntos espirituales, en contrarrestar la influencia del protestantismo y continuar con programas de corte asistencialista, pero mantenerse al margen de las cuestiones políticas, como se puede leer en el documento de la Primera Conferencia del Episcopado Latinoamericano de Río de Janeiro, en 1955.

Sin embargo, esta posición conservadora eclesiástica no fue suficiente para detener el ímpetu de muchos de sus miembros, incluyendo al alto clero, que estimulaban una postura crítica hacia los modelos económicos capitalistas que generaban más desigualdad social entre los Estados del otrora llamado "tercer mundo".

La idea de incluir a los sectores marginados y oprimidos como motivo de lucha y de un discurso crítico fue expandiéndose e influyendo en las generaciones de jóvenes religiosos y fieles católicos. Era claro que la reforma conciliar no sólo impulsó cambios al interior de la Iglesia, sino que hacía de ella un organismo que se involucraba con la realidad extramuros y formaba una mayor conciencia hacia la vulnerabilidad social. Esto permitió, como expresa Gustavo Morello (2007, p. 92), que las “[...] iglesias periféricas generaran un intento propio de reflexión teológica muy vinculado a lo particular y concreto de las situaciones de cada 
región". Esta reflexión teológica propia, señala Morello, explica la postura de esta Iglesia cristiana hacia el ámbito revolucionario en América Latina que se vivía en Cuba, Centro y Sudamérica, pues "surgieron de la reflexión teológica sobre la realidad social de la región" (Morello, 2007, p. 92).

Así como la acción del catolicismo latinoamericano se concentró durante la primera mitad del siglo XX en combatir el protestantismo que estaba ganando terreno en el continente, con la Iglesia posconciliar latinoamericana el motivo de lucha se transformó para asumir una posición antisistémica y anticapitalista.

En 1968 esta postura anticapitalista y antiimperialista de la Iglesia católica latinoamericana fue más visible, pues mostró una actitud de apoyo a la población oprimida que, por lo general, se concentraba en el sector rural y proponía su liberación inspirada en las ideas revolucionarias que formaban parte del contexto latinoamericano, en el mensaje del Concilio Vaticano II, en las teorías e ideologías que surgían o se construían en otros campos de la intelectualidad latinoamericana, como la teoría de la dependencia y la filosofía de la liberación, entre otras.

Entre los hechos cruciales que representan el pensamiento "liberador" de este catolicismo de izquierda está la organización y desarrollo de la Segunda Conferencia General del Episcopado Latinoamericano, así como el evento previo y preparativo de éste, los cuales se llevaron a cabo en la ciudad de Medellín y Melgar, Colombia, respectivamente, en 1968.

Aunada a la fuerte presencia ideológica centrada en el modelo de la Revolución cubana, así como la oleada de ideas inspiradas en principios de corte marxista, en adelante la participación de 
misioneros o agentes de pastoral laicos y religiosos ${ }^{1}$ comenzó a producir cambios, es decir, pasó de una acción pastoral doctrinaria y pasiva a una comprometida, crítica y no exclusiva de la vida consagrada, sino también laica o no confesional.

En este contexto nació una pastoral de la teopraxis ${ }^{2}$ e in situ que observaba con detenimiento las necesidades y particularidades de la población oprimida, lo que llevó a identificar una gran diversidad cultural que inspiró la puesta en marcha de una pastoral indígena a nivel latinoamericano.

En la actualidad hay una labor eclesiástica con métodos lejos de la confrontación, como en los momentos más críticos en Centroamérica en la década de 1980, pero con bases ideológicas centradas en el diálogo ecuménico y entre las culturas como una forma de liberación.

En contextos étnicos, por ejemplo, la tarea de la Iglesia católica ha ido variando de una acción etnocida - tal como se cuestionó en la ciudad de Melgar en 1968, antes de la celebración

${ }^{1}$ Se tiene la idea de que los colaboradores de la Iglesia católica en la actividad pastoral son misioneros. Los propios misioneros, como han explicado en Chiapas y Guatemala, no se llaman de esa forma porque son agentes de cambio dentro de esa actividad. En el Concilio Vaticano II aún se habla de misión y de misioneros, pero ha sido en los documentos de diversos sínodos diocesanos y en la terminología de organismos como el Centro Nacional de Ayuda a la Misiones Indígenas, A.C., entre otros, que se utiliza el término agente de pastoral. Por otro lado, esto no se concentra necesariamente en sacerdotes o en la vida consagrada, sino que incluye laicos. Como se expondrá más adelante en este texto, la participación y contratación de gente laica o seglar en las actividades de las "misiones" y ONG religiosas es tan común, que incluso rebasa la cantidad de religiosos. Es entonces cuando se comprende el calificativo que en el Concilio Vaticano II se tiene de "misionero laico".

${ }^{2}$ La antropóloga Enriqueta Lerma (2019) hace uso del término teopraxis, basada en Alberto Iniesta, para referirse a una teología práctica de la comunidad cristiana, con sus planteamientos, orientación y posible desarrollo. Se trata de una reflexión teológica que se encarna en cada contexto, es una práctica teológica y pastoral in situ. 
de la Segunda Conferencia General del Episcopado de América Latina (CELAM) en Medellín- a una en conjunto, con la intención de ser cada vez más horizontal, involucrada política y socialmente, con el propósito de evitar las relaciones de dependencia entre los más desfavorecidos, reconocer la diferencia étnica y religiosa de los pueblos indígenas e impulsar y dar fuerza a las bases sociales indígenas en tanto comunidades civiles capaces de trabajar y dialogar con instancias gubernamentales y no gubernamentales en defensa y lucha por sus derechos, en una suerte de gobernanza desde la pastoral.

La batalla de un organismo tradicionalmente colonialista por la liberación de un pueblo de este yugo de opresión debido a los modelos económicos, políticos y culturales actuales, le valió en un principio una división muy clara entre un sector conservador y otro de izquierda, pero también generó una conciencia étnica, respeto a la diversidad de credos y cosmovisiones (que aún no son aceptados del todo en la Iglesia), pero, sobre todo, logró establecer un ideal de construir una Iglesia desde y por los indígenas, lo que implica una lucha por que éstos logren una independencia de los programas y modelos asistencialistas.

Hoy en día, y a partir de las reflexiones que han madurado desde la Iglesia posconciliar a lo largo de la segunda mitad del siglo XX, la Iglesia católica a la par de otras denominaciones cristianas no católicas no pueden estar del todo ajenas a las circunstancias sociopolíticas, socioculturales y socioeconómicas que se observan a nivel global. La situación de crisis política del Estado-nación ha impulsado una actividad desde la sociedad civil que intenta retomar las riendas de la democracia, acaparada por grupos de poder que se supone que representan a la 
sociedad civil misma. Sin embargo, la exclusión es clara a partir de esa representación.

Así como se advierte la intención de la Iglesia católica y de otros actores de abandonar acciones e iniciativas asistencialistas y de representación del otro, también se han posicionado en una lucha por romper con la exclusión y propiciar que las poblaciones a las que se dirigen logren una firme autosuficiencia y autosostenibilidad como vía de liberación, además de propiciar un escenario de acercamiento a actores como el Estado o líderes empresariales, para establecer acuerdos de respeto y reconocimiento recíproco. Desde este punto, es posible hacer mención de la gobernanza.

Lo que se denomina o concibe como gobernanza llega a ser difuso porque se trata de una noción que se ha ido transformando con el tiempo. A reserva de que este tema se abordará en un apartado específico, es importante aclarar que la gobernanza, desde la década de 1980, se asumía como una dirección política a partir de dos características: por un lado, la capacidad de abarcar la totalidad de las instituciones y relaciones implicadas en el proceso de gobierno; por el otro, desde una perspectiva más global, se concentraba en organismos internacionales como la Naciones Unidas, el Fondo Monetario Internacional o el Banco Mundial, para reformar las políticas y redes de participación ciudadana en los llamados países del tercer mundo.

En la actualidad esta perspectiva se ha transformado, pues la gobernanza "apunta a la creación de una estructura u orden que no se puede imponer desde el exterior, sino que es resultado de una multiplicidad de agentes dotados de autoridad y que influyen los unos en los otros" (Kooiman \& Van Vliet, 1993, p. 64). Esto 
significa que se conforma una suerte de interacción o sintonía

armónica y dialogante entre tres actores fundamentales: sociedad civil o actores sociales, Estado o gobierno y los actores económicos, como se observa en la figura de abajo, tomada de un artículo de Nain Martínez e Ileana Espejel (2015), donde se advierte una clara diferencia entre gobernanza y gobernabilidad.

Figura 1. Elementos para diferenciar los conceptos de gobierno, gobernabilidad y gobernanza

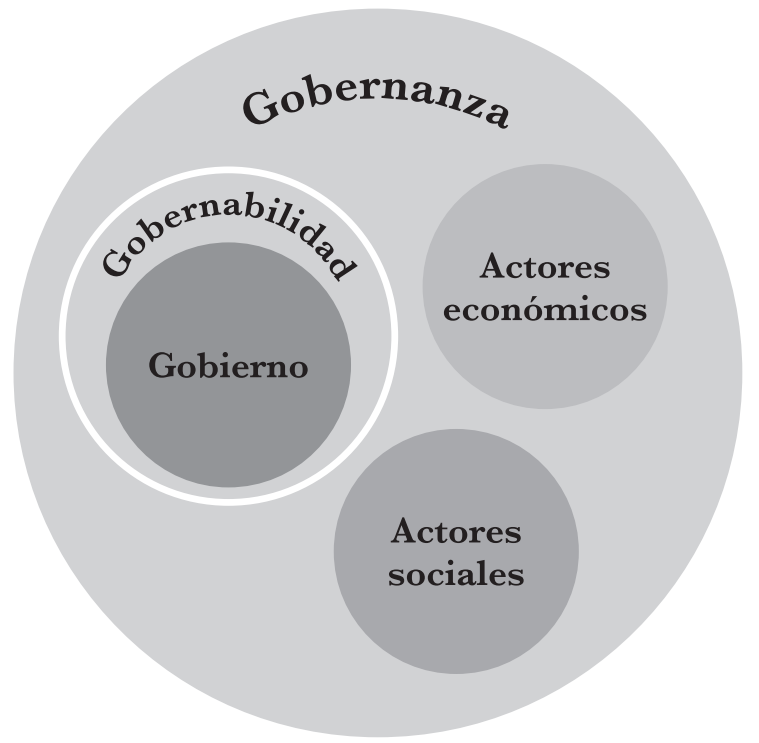

Fuente: Martínez \& Espejel, 2015, p. 162.

En este orden de ideas, si se considera a los habitantes de las comunidades y pueblos indígenas como actores sociales y/o sociedad civil ante la tendencia de los actores económicos o el Estado mismo de "hablar por ellos", de concebirlos como sujetos 
pasivos e introducirlos en prácticas asistencialistas, se observa una exclusión de ellos y no de una relación horizontal y dialógica. La pastoral indígena, pese a adjudicársele una mecánica asistencialista en sus inicios, hoy funge como una vía de empoderamiento de estos pueblos indígenas y tiene el papel de facilitar la construcción de un espacio de interacción más horizontal. Por esta razón, se asume que a través de ella puede hablarse de una suerte de gobernanza en la acción pastoral o, por lo menos, que se sigue un proceso o construcción de un escenario de gobernanza, con una vocación más incluyente, horizontal y menos representativa, a manera de liberación y reversión de la situación de vulnerabilidad en la que se encuentra la mayor parte de los pueblos indígenas en América Latina y otros lares.

La propuesta general en esta obra es entender, por una parte, la acción de la pastoral indígena, pero también cómo se ha ido adaptando y transformando hasta vincularse con prácticas y contextos más allá de una lucha y oposición a las estructuras conformadas por otros actores aparte de la sociedad civil; es decir, una teopraxis más tendiente a lo que se concibe como nueva gobernanza, concepto que se desarrollará más adelante.

Para tal efecto, es importante explicar las bases o principios en los que se ha fundamentado la pastoral indígena y su dinámica "evolutiva" -teología de la liberación, teología de la inculturación, teología india, ecoteología, entre otras-, de la que escasamente se ha hecho un análisis, pues cuando se habla de cultura de la gobernanza o sencillamente gobernanza el enfoque tiende a centrarse en organismos internacionales y organizaciones no gubernamentales, pero no involucrados con una praxis sobre todo de corte religioso y en un escenario pluricultural, en este 
caso en la región que comprende el sur y sureste de México y, en menor medida, Guatemala.

En este libro intervienen muchas fuentes de investigación, que van desde la revisión de volúmenes y artículos especializados, documentos teológicos como el Concilio Vaticano II o los documentos de las cinco CELAM, recopilaciones y memorias de encuentros de teología de la liberación y pastoral indígena, entre otros. Pero una base importante de reflexión y construcción del fenómeno sociorreligioso y la pastoral indígena desde sus orígenes en el entorno del sur y sureste mexicano actual es el testimonio de quienes han formado parte de estos procesos.

La forma de obtener y procesar la información, que en su mayoría es difícil de encontrar en textos académicos, fue a través de entrevistas abiertas, observación etnográfica y participante, que desde 2007 se ha realizado en Guatemala (Totonicapán), el sureste mexicano (Chiapas) y, un poco, en el estado de Oaxaca.

La recopilación de este material y la revisión de experiencias etnográficas y vivenciales están fundamentadas en la interacción y discusión con agentes de pastoral implicados en estos contextos que han sido activos teólogos de la liberación en Centroamérica y México, así como con individuos que vivieron el liberacionismo y la pastoral indígena en su formación educativa y catequización en México, Guatemala o Ecuador.

La importancia de la presente obra no se constriñe a la compilación de esta información para mostrar monográficamente una temática tan compleja como la pastoral indígena, sus bases en la teología de la liberación, en la inculturación, la teología india y un sinfín de vías y procesos para construir una Iglesia autóctona. Una 
propuesta con este material y el tema a desarrollar es comprender en la historia y (teo)praxis de la pastoral indígena y su evolución hasta nuestros días la acción de un actor fundamental, que es el agente de pastoral, como parte de un organismo milenario como lo es la Iglesia católica; pero, sobre todo, la sociedad civil representada en los habitantes de los pueblos indígenas y campesinos del sur y sureste mexicanos, así como la zona centroamericana en general. Esto, con el fin de abordar un tema en boga hoy a partir de la realidad de una estructura estatal en franca crisis y la apuesta de crear un escenario de diálogo basado en los actores económicos, el Estado y la sociedad civil, es decir, la gobernanza.

Parece complicado pensarla como un término, concepto, praxis y alternativa novedosa. Sin embargo, en el ámbito religioso, en específico el de la pastoral indígena, puede leerse o identificarse alguna insinuación de su contenido teórico en la praxis misionera, aunque es un aspecto escasamente abordado, por no decir casi inexistente, en la literatura. Es difícil y aventurado en estos momentos hablar de una gobernanza de la pastoral sin caer en la tendencia de crear neologismos que conforman glosarios que son rápidamente rebasados y actualizados con otros términos. En este sentido, la propuesta de este trabajo es hablar de la pastoral indígena y la praxis de la Iglesia católica de izquierda en contextos indígenas y campesinos en la gobernanza.

En ese orden de ideas, esta publicación pretende hacer un análisis teórico y conceptual de la pastoral indígena con las corrientes teológicas que conlleva -teología de la inculturación, teologías indias, teología de la liberación, entre otras-, con el propósito de entender no sólo la transformación de la Iglesia católica latinoamericana a través de una revisión histórica o la 
clasificación de la pastoral indígena según el caso o contexto de que se trate, sino discernir la participación de la sociedad civil representada en estos pueblos indígenas en diálogo con otros organismos; es decir, una dinámica social y religiosa similar a lo que podría definirse (considerando que el concepto está en

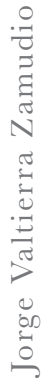
permanente construcción y replanteamiento) como una nueva gobernanza. 


\section{CAPítuLO 1}

\section{LOS GONSTRUGTORES DEL REINO DE DIOS EN EL SUR DE MÉXICO: LA TRANSFORMAGIÓN DE LOS "MISIONEROS" EN LA IGLESIA GATÓLIGA POSGONGILIAR}

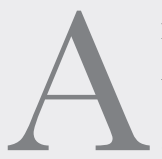

nte temas como la acción pastoral católica actual, sobre todo aquella empapada de esta noción de una Iglesia de los pobres, es común hacer mención de la teología de la liberación como antecedente y escenario en que se ha desarrollado el "ala de izquierda" de la Iglesia católica latinoamericana. Sin embargo, puede cuestionarse la idea que se tiene de la teología de la liberación en tanto movimiento homogéneo en el que sacerdotes y laicos cristianos comprometidos y con una posición político-ideológica de izquierda estaban involucrados, esto es, presenta varias naturalezas y contextos que rompen con esa uniformidad conceptual.

En estos términos, tratar de definir la acción pastoral y sus cambios a lo largo del siglo XX se torna complejo, porque se ha desarrollado en una gran diversidad de entornos geográficos, sociales y políticos específicos. Un ejemplo representativo de lo anterior es la zona de Centroamérica, en donde había una situación dominada por una serie de movimientos sociales integrados por "diversos grupos o sectores de clase que experimentan en común diversos grados de subordinación y explotación por parte de un sector de la clase dominante y de represión por parte 
del Estado" (Torres-Rivas, 2013, p.16). Este tipo de movimientos surgía en buena parte del Istmo continental, en especial en Nicaragua, El Salvador y Guatemala.

Cierto es que en estos lugares dichos Estados centroamericanos compartían entornos y problemas comunes, como la explotación, la desigualdad social o la exclusión y, por lo tanto, sus luchas presentaban objetivos similares en contra de estos problemas. La pertinencia de la acción eclesiástica en esta situación se define con lo que se denomina teología de la liberación o liberacionismo, pero tiene una naturaleza más compleja.

El liberacionismo se explica como un movimiento eclesiástico y pragmático, por ejemplo, en una atmósfera de tensión o de guerra civil centroamericana que se fue desarrollando y creciendo. Mucho de la expansión de la teología de la liberación se alimentaba del mensaje del Concilio Vaticano II (1962-1965), bajo el pontificado de Juan XXIII, y otros eventos en los que sobresalía una postura crítica y analítica de la realidad, así como una actitud de reivindicación de la dignidad humana y una disposición de abrirse a un diálogo con el mundo moderno, en lo que se denomina aggiornamento o puesta al día.

También es importante mencionar la influencia ideológica que significó el triunfo de la Revolución cubana en 1959, pues "animó numerosas y polisémicas empresas revolucionarias entre quienes consideraron lícita la violencia como expresión de formas heterodoxas de confrontación al imperialismo estadounidense" (Bedolla, 2017, p. 186), de lo que se tienen muchos ejemplos, como en Centroamérica la Revolución sandinista o el periodo revolucionario en Guatemala, ambos en la década de 1960 (Vázquez \& Campos, 2016). 
En este orden de ideas, la expresión militante del catolicismo latinoamericano a favor de los pobres - sin decir que optaba por la violencia como una forma de liberación de los pobres y oprimidos- simpatizó con el discurso y movimiento revolucionarios como vía para contrarrestar la realidad de sobajamiento en la que se encontraban los campesinos y obreros en el subcontinente latinoamericano.

La teología de la liberación o liberacionismo, sin embargo, se gestó en distintos contextos; es decir, en un espacio intelectual a favor de los pobres y por la emancipación de los oprimidos, pero en un plano más bien teórico. Por otro lado, existe una acepción militante, un movimiento en el que sacerdotes y religiosos involucrados con la población campesina y urbana actuaban y luchaban por su causa. De esto último se observan casos radicales, como el del sacerdote colombiano Camilo Torres Restrepo, que formó parte de las filas del Ejército de Liberación Nacional en Colombia y murió en combate, así como hay ejemplos menos extremos, entre ellos el de Leonidas Proaño, que ejerció una militancia desde su jerarquía episcopal con el pueblo kichwa en la diócesis de Riobamba, Ecuador.

Por otro lado, en un plano más teórico-intelectual están los llamados fundadores de la teología de la liberación, como Gustavo Gutiérrez, Jon Sobrino o Pablo Richard quienes sin decir que no estaban comprometidos con el movimiento, lo desarrollaban más desde la teología y la filosofía. La diferencia dentro de la definición de la teología de la liberación es que ésta es una reflexión de fe (teología) a partir de la realidad de las poblaciones más vulnerables de Latinoamérica. 
En cualquier caso, el liberacionismo como un movimiento que lucha por la emancipación del estado de sujeción, explotación y marginación de muchos sectores de la población latinoamericana -como consecuencia de los modelos económicos liberales y el nuevo orden mundial que deriva de la redefinición geopolítica después de la Segunda Guerra Mundial- por definición no se contempla en una praxis pastoral en y hacia la diversidad cultural y étnica como elemento innato en las sociedades latinoamericanas, además de que por las necesidades y particularidades de cada comunidad no podría generalizarse con la sola noción de pobreza o en una vocación integral de todas las dimensiones de opresión de la vida humana y social (Bedolla, 2017).

En el contexto centroamericano, para continuar con el ejemplo de esta zona geográfica, las diferencias que no se percibían en la práctica pastoral liberacionista partían de la etnicidad, esto es, mientras en El Salvador o Nicaragua gran parte de la gente en lucha era de origen mestizo y campesino (así se concebía a los actores que conformaban el movimiento), había una omisión de la diversidad demográfica y cultural representada por mestizos, afrodescendientes y en algunos casos nativos o indígenas.

En Guatemala, a pesar de ser Centroamérica, la situación es distinta porque ahí prevalecen las poblaciones indígenas de filiación mayense, garífuna y xinca, que conforman buena parte de la sociedad guatemalteca. Allí, la acción pastoral, aunque con principios liberacionistas, debía adaptarse a esas particularidades y diferencias socioculturales y sociolingüísticas. Entre los aspectos que ocurrieron en Guatemala, a diferencia de El Salvador o de Nicaragua, está que la acción pastoral debía ser una que se asimilara y adaptara en las culturas, en una suerte de lo que más 
adelante se llamaría teología de la inculturación, lo que no exime a dicha acción pastoral de algunas bases liberacionistas.

Esta transformación se mencionó en numerosas ocasiones y generó debates a lo largo de las décadas de 1960 y 1970. Después del Concilio Vaticano II (1962-1965), la Segunda CELAM de Medellín en 1968 y la Tercera de Puebla, en 1979, en los que se había consolidado el propósito de una Iglesia por los pobres y por la liberación de los oprimidos, se explica el involucramiento de una buena parte del sector católico latinoamericano en los problemas que representan los movimientos sociales en esta región. Sin embargo, ya desde Puebla 1979 se hablaba de un respeto a la diferencia étnica con términos como teología india o pastoral indígena en las zonas en donde se veía esta realidad, como México, Guatemala, Colombia, Ecuador, Bolivia, entre otros.

La parte primordial del contenido de estos debates se llevan a la práctica a través de un proceso de evangelización con un tono o simpatía revolucionaria, pero en congruencia con el cristianismo, al menos discursivamente, por el sentido de sacrificio y la conformación de las Comunidades Eclesiales de Base (CEB $)^{3}$ que coadyuvaban en la formación y captación de los campesinos en

${ }^{3}$ Las Comunidades Eclesiales de Base son espacios donde, advierte Boff (1979), se contrapone un modelo piramidal de la Iglesia con uno circular que alude a la horizontalidad que debería mostrar. En este último se expresan las notas teológicas de la Iglesia en la base. Las CEB son "expresión del movimiento de renovación eclesial del Concilio Vaticano II y, contextualizado en América Latina en los años sesenta, momentos en los que el proyecto de desarrollo promovido por Estados Unidos comenzaba a manifestar su debilidad. La pobreza de los pueblos de este continente no se debía al atraso en la carrera del desarrollo, sino por los mecanismos de explotación y de dependencia de estos pueblos con respecto a los países ricos" (Sánchez, 2007, p. 54). 
y desde la teología de la liberación. Esto constituyó un pilar muy visible, por ejemplo, en el proceso revolucionario salvadoreño y, en menor medida, en Nicaragua con la presencia de jesuitas que estuvieron involucrados de forma paralela al Frente Sandinista de Liberación Nacional. ${ }^{4}$ Sin embargo, en Guatemala la situación fue distinta.

El misionero jesuita y antropólogo Ricardo Falla, de la misión de Santa María Chiquimula, Guatemala, refiere más a un proceso de inculturación que de liberación. Él alude al pueblo quiché con el que ha trabajado y una pastoral por parte de los misioneros jesuitas muy diferente; no un acompañamiento pastoral de impartir la palabra de Dios, ni uno de imponer la fe, sino uno de ir discerniendo la cultura para encarnar el mensaje de Dios en la cosmovisión quiché. Explica Falla en este proceso

${ }^{4}$ Es importante considerar las memorias de encuentros en las que, desde una perspectiva liberacionista y revolucionaria, es visible la captación del campesinado y el papel destacado de la teología de la liberación. La presencia de los religiosos que participaron en tales dinámicas es muy evidente en estas memorias, como los jesuitas que en diálogo con, por ejemplo, líderes revolucionarios y dirigentes de Nicaragua convocan a simposios donde se revisa y examina "la relación entre Revolución sandinista y fe cristiana, entre praxis -o práctica- y conciencia revolucionaria, por un lado, y testimonio y conciencia religiosa por otro" (Argüello, 1979, p. 5). Luego del triunfo de la Revolución sandinista en Nicaragua se hacían análisis en los que abordaba una posible intervención de Estados Unidos y el capitalismo, así como el apoyo que el cristiano debía dar a una lucha legítima de liberación. El jesuita Juan Hernández Pico establecía que había retos ante el triunfo de la Revolución en Nicaragua: "el reto de qué apoyo dar, como cristianos, a un poder fundamentalmente nuevo aunque amenazado con amenazas internas y externas [...] qué poder popular realmente se está creando y cómo estamos contribuyendo a crearlo; y dentro de este poder cómo crecen los más olvidados, los que más necesitan de un despertar cultural, de un rescate de su ser de hombre, qué tipo de estado se está conformando, y qué libertad mantenemos nosotros frente a él, para favorecer sin ingenuidad política ninguna y desde dentro del proceso revolucionario, una presencia participativa del pueblo, del poder popular del estado [...]” (Hernández Pico, 1980, p. 36). 
que "[...] hay algunos que dicen que lo que se dio ahí, a pesar de que tiraron muchos símbolos al barranco, sin embargo, fue verdadera inculturación, se apropiaron del verdadero mensaje cristiano [...] se ve como una liberación de las culturas de los antepasados" (Falla, entrevista, 2008).

Lo anterior significa que la situación que muchos misioneros experimentaron en Guatemala, en un contexto de "guerra" que alcanzó su punto más dramático y sangriento en la década de 1980, fue la diversidad cultural y debían hacer algo más que adaptarse, como una suerte de asimilación en esas cosmovisiones. No se trataba de llevar a cabo una acción pastoral como en otros entornos culturalmente más homogéneos, sino de comprender las lógicas, cosmovisión y prácticas culturales de poblaciones quichés, q'eqchies, chujes, kanjobales, tzutujiles, pokomames, mames, cakchiqueles, entre muchas otras.

Así trataron de hacerlo los salesianos, jesuitas, dominicos, la Maryknoll (Catholic Foreign Mission Society of America), entre otros, y en muchos casos con poco éxito, no sólo por la llegada de grupos cristianos no católicos, sino por movimientos desde estos grupos indígenas con el fin de "recuperar" su religiosidad autóctona maya, en lo que se concibe como Movimiento Maya, que "en varios casos llegaban a rechazar el catolicismo y cristianismo en general" (Valtierra Zamudio, 2018a, p. 261), lo que logró tiempo después no sólo fortalecer y revitalizar sus rasgos religiosos y culturales, sino que la religión también se tornó en un componente importante del activismo por sus derechos culturales (Esquit, 2004).

El ejemplo expuesto en el caso centroamericano ilustra la gran diversidad de circunstancias de corte político y social, y 
que, pese a compartir algunos aspectos, metas y objetivos que se concentran en el proceso revolucionario, hay un punto que modifica estos esquemas de manera considerable: la etnicidad.

La elección de Centroamérica como uno de los grandes ejemplos de lo que sucedió y de la transformación de la teología de la liberación durante las décadas de 1960, 1970 y 1980, obedece a que es el contexto en el que se puede entender el sur y sureste de México. En cuanto a los motores ideológicos de un movimiento eclesiástico de esta talla, es evidente la relación que hubo entre México y El Salvador o Nicaragua, incluso Colombia y Ecuador, aunque estos últimos con condiciones y situaciones culturales muy diferentes, pero también se compartía una buena parte de la complejidad étnica de Guatemala en estados como Chiapas, Veracruz y Oaxaca, donde si bien podría decirse que se desarrolló la teología de la liberación, tuvo tintes de una pastoral indígena y de teología de la inculturación.

Centroamérica puede ser parte de un contexto general similar al del sureste mexicano, tanto en lo relativo a la diversidad étnica como en la influencia revolucionaria. Pero en el caso específico de Guatemala, los procesos de inculturación y de teología india - que significan la transformación del liberacionismo a una pastoral integral e intercultural- tienen una mayor cercanía con la experiencia mexicana, sobre todo en la diócesis de San Cristóbal de Las Casas, en el estado de Chiapas, y la diócesis de Tehuantepec, en el estado de Oaxaca.

En este capítulo se pretende explicar el proceso de cambio de la Iglesia católica latinoamericana, que va de una posición más bien doctrinaria a una progresista y luego a una de diálogo intercultural e interreligioso, por medio de ejemplos concretos como 
Guatemala, Oaxaca y Chiapas. Para ello es importante definir y comprender la historia de la teología de la liberación desde una perspectiva global y, posteriormente, abordarla desde una óptica local o in situ e in praxis, en un entorno indígena.

\section{Origen y contexto de la teología de la liberación}

Cuando se alude al cristianismo, debe pensarse también en el fenómeno social e ideológico que conlleva. No se trataba de un movimiento doctrinario que haya surgido como un ente apartado y constreñido a una divinidad metafísica y ultraterrena, sino que pertenece a una realidad política, social, cultural, económica, ideológica y terrenal.

$\mathrm{Al}$ ser Europa la región en donde más se desarrolló e interpretó el movimiento cristiano, es evidente la naturaleza eurocentrista de la organización que se fundó. Sin embargo, una característica que ha tenido el cristianismo con su centro en Europa es la difusión de su mensaje que, en apariencia, se adapta a la cultura a la que se dirige, a través del ejercicio de evangelizar.

La labor evangelizadora de la Iglesia católica por medio de los misioneros no se concentra sólo en "dar la palabra de Dios" y gestionar los asuntos espirituales, es claro que hay una intervención y participación política en el contexto en el que se encuentra. Así ha sido a lo largo de los siglos en Europa y, más recientemente, en Latinoamérica y Asia. En los más de dos mil años de existencia de este organismo alrededor del mundo, el clero ha sido determinante en su funcionamiento, en la toma de decisiones en materia política y en su estructura social misma. 
En la actualidad, la acción política de la Iglesia católica en una suerte de teopolítica es muy visible con ejemplos como la pastoral de la movilidad, asociaciones religiosas en defensa de los derechos humanos o algunas estructuras similares a las CBE en las que se forma a la población en cuestiones que refieren a los problemas y realidades que se viven en diferentes contextos, tanto rurales como urbanos. Puede observarse que la práctica política y social de la Iglesia no es algo reciente. Sin embargo, fuera de Europa, ha sido el siglo XX cuando más cambios se han visto en esta organización, es decir, de ser predominantemente asistencialista y doctrinaria se transformó paulatinamente en más activista y politizada.

La raíz de esta transformación ideológico-política de base o "desde abajo" en el catolicismo coincide con el hecho de que la doctrina eclesiástica adquirió un perfil más social. Fue a finales del siglo XIX, en la época del papa León XIII, cuando se hizo pública la encíclica Rerum Novarum (1891), con la que definió la postura eclesiástica a favor de la clase trabajadora, lo que no significa que hubiera una tendencia de carácter socialista, sino una suerte de línea ideológica que se encontraba en medio del socialismo y el liberalismo, esto es, estaba en contra tanto de los efectos del liberalismo económico sobre la clase trabajadora como del socialismo que "arrebataba las masas a la Iglesia" (Blancarte, 2012, p. 23).

Este fenómeno de cambio se conoce en la Iglesia católica como Doctrina Social Católica (en adelante DSC) y representó una institución con los ojos más puestos en el mundo terrenal y contemporáneo. Sin embargo, para el sociólogo Roberto Blancarte el interés de la Iglesia no era sólo social, buscaba también defenderse de los efectos que las revoluciones burguesas y liberales habían desatado desde la Revolución francesa de 1789 y a 
lo largo del siglo XIX en Europa, pues, advierte Blancarte (2012, p. 23), subvertían "los valores y el orden establecido en las mismas potencias católicas". De esta forma se explica la postura de la Iglesia frente a los movimientos liberales.

Con respecto al socialismo, la Iglesia lo concebía como un subproducto del liberalismo, que también implicaba una amenaza para el clero. La DSG buscó, entonces, romper con este panorama conformado por el liberalismo y el socialismo. La publicación de la Rerum Novarum tuvo un impacto considerable por su posición crítica hacia los gobiernos y actores económicos o empresarios que generaban desigualdad social.

En América Latina, el catolicismo asumió durante la primera mitad del siglo XX una labor que implicaba tener más contacto con la gente. A excepción de México, donde las relaciones con el Estado estaban muy deterioradas - debe recordarse el periodo de persecución y violencia con la llamada Guerra Cristera (19261929)-, en el resto del subcontinente la Iglesia se posicionó con fuerza y las relaciones con los Estados en general fueron buenas, a pesar de la proliferación de políticas liberales que se percibían como anticlericales (Bastian, 2011).

Más allá de estos hechos, el efecto de esta Iglesia social se filtró paulatinamente hasta construir un escenario ideal de seguir una línea desde la Iglesia y el pueblo para contrarrestar la opresión que representaban los opulentos, al principio como crítica y después como elaboración de una acción pastoral, aunque todavía asistencialista.

Por teología de la liberación puede entenderse una reflexión de fe que fundamenta su crítica en las consecuencias sociales que ha traído la modernidad y que tiempo después ésta continúa con 
el modelo neoliberal como resultado de la globalización. José Sánchez es más preciso cuando se refiere a las secuelas:

[de una] extraordinaria concentración de la riqueza en pocas manos, al mismo tiempo que un proceso de exclusión de las mayorías a los bienes del progreso moderno. La pobreza a grandes pasos ya no únicamente en los países pobres, sino en las mismas entrañas de los países ricos. Nunca antes había habido en el planeta tanta producción de bienes y al mismo tiempo tanta carencia de ellos, al grado de que pueblos enteros mueren de hambre. El 20 por ciento de los habitantes de la Tierra goza del 80 por ciento de las riquezas que se producen, mientras el 80 por ciento de los habitantes pueden disfrutar tan sólo del 20 por ciento de ellas. Quien no produce y consume no tiene lugar en este mundo globalizado. El proyecto neoliberal provoca grandes contrastes entre las personas y los pueblos (Sánchez, 2007, p. 52).

Cuando se piensa en los orígenes de la teología de la liberación deben considerarse todas estas acciones de lucha ante la opresión. No es extraño que Enrique Dussel conciba el principio del liberacionismo a partir de una constante batalla por la liberación de la opresión y ponga como representante de esta acción a fray Bartolomé de Las Casas, que hable de las revoluciones de independencia iberoamericanas en las que participaron muchos representantes del clero como, en el caso mexicano, Miguel Hidalgo, José María Morelos, Mariano Matamoros, entre otros; o de la etapa neocolonial que se registra alrededor de la década de 1930 (Dussel, 1995).

Todas estas fases de liberación que remiten a una Iglesia social, en el sentido de una noción y praxis de una Iglesia más en 
contacto con la gente, anteceden a la teología de la liberación de los años sesenta. Por esa razón, determina Dussel (1995, p. 42), el liberacionismo "[...] no nace en la academia, sino en el fragor de la lucha misma". Sin embargo, no puede negarse que también hay una estructura institucionalizada. La teología de la liberación conlleva una doble naturaleza: una que consistió en la radicalización de la DSC y de la Iglesia Social como tal, y otra más de corte académico-intelectual que, al cabo, se fundamentaba y vinculaba con la primera.

De la misma forma que Dussel, Phillip Berryman (2014) intenta explicar el origen de la teología de la liberación en una serie de etapas históricas que inician, en este caso, con los movimientos de independencia de las colonias iberoamericanas como punto de partida y motivo de lucha por la liberación. Sin embargo, en los resultados de estas revoluciones que discursivamente evocan a la liberación del pueblo, las masas ni siquiera fueron reconocidas, obtuvieron pocos beneficios y la opresión sólo dejó de ejercerse desde los peninsulares para cambiar de manos a criollos y mestizos. Es por ello que a esto se le conoce como neocolonización o etapa neocolonial.

En cualquier caso, en pleno siglo XX y con la llamada Iglesia Social y la DSC, el propósito de contrarrestar la explotación del pueblo -que se concentraba más en el ámbito rural y, por lo tanto, con una presencia considerable de población indígenase intentaba llevar a cabo mediante una serie de acciones para generar conciencia. Se organizaban algunos espacios de discusión acerca de lo que ocurría en el mundo, aunque todavía con un tono tímido, pero muchas de estas iniciativas se inspiraron en los hechos atroces de la Segunda Guerra Mundial y un ambiente 
complejo en el que la Guerra Fría es protagonista. Quizá el mayor ejemplo es la Primera Conferencia General del Episcopado de América Latina, organizada en Río de Janeiro, Brasil, en 1955, donde se reunieron varios obispos de Latinoamérica para discutir sobre temas que en ese momento preocupaban a la Iglesia, sobre todo acerca de la proliferación del llamado "protestantismo", así como la expansión del comunismo y el secularismo en América Latina (Berryman, 2014).

Pronto estos temas se irían transformando a la par del incremento de la desigualdad social en el mundo, principalmente al interior de los países del "tercer mundo". Para 1960 la Iglesia latinoamericana continuaba con la idea de asumir una posición social, pero con algunos cambios, es decir, una transformación ideológica a raíz de la situación general que había en el mundo, por lo que la Iglesia católica latinoamericana se convertía en un organismo que estaba dividido, por un lado, en un sector más conservador u ortodoxo que se mantenía al margen de la realidad social, política y económica, y, por el otro, en un sector conformado por jóvenes sacerdotes y obispos con un mayor contacto con la población que mostraba una postura crítica, incluso contestataria.

Esto no sucedía sólo en América Latina, sino en otros contextos como África, que era una zona en donde se mantenía una posición crítica hacia la pastoral aun antes de celebrarse el Concilio Vaticano II (Shorter, 1988). Al igual que en Latinoamérica, en África se vivía opresión y marginación, incluso esclavitud, que denotaba una profunda precariedad económica.

En este contexto, a partir de la década de 1960 la acción pastoral católica y la acción pastoral protestante se orientaban 
a una teología africana crítica que, en esencia, sintetizaba las corrientes de la teología de la liberación y de la teología de la inculturación (Shorter, 1988) en busca de comprender el mundo y la cultura africanos e identificar sus problemáticas, por lo tanto, de reconocer la diversidad cultural y de credo de aquellos pueblos.

La mención de África al respecto es porque en este afán de una teología liberadora, se trata también de una praxis que intenta adaptarse a las particularidades culturales e ideológicas de la región, en una suerte de descolonización no sólo de los territorios africanos, iniciada en la década de 1950, sino de la teología universal.

En el caso de América Latina la situación fue un poco distinta, pues la presencia de la acción pastoral, tanto católica como protestante, si bien se involucraba con la realidad de los pueblos campesinos, conformados en buena parte por indígenas, su interés y construcción se enfocaba en liberarlos de la opresión en la que vivían y fue tiempo después cuando se reconocería la diversidad cultural. ${ }^{5}$

Uno de los acontecimientos más importantes que cimbraron al mundo fue la llamada Guerra Fría, también al interior de la Iglesia católica y su praxis este suceso tuvo un fuerte impacto, además de estar en apogeo durante la puesta en marcha de la

${ }^{5}$ Es probable que la falta de visión de la pastoral liberadora católica en América Latina se relacionara con la perspectiva más doctrinaria y conservadora que se interesaba en un inicio en combatir el protestantismo. Sin embargo, en la praxis los llamados protestantes -como los menonitas en el Chaco argentino- ya daban muestras de formas y vías para discernir la cultura del otro en una suerte de inculturación que el catolicismo asumiría más tarde, después de acalorados debates y críticas que se hacían desde distintas instancias, principalmente académicas, que indujeron un cambio metodológico de lo que sería una teología de la liberación más concentrada e inspirada en la reforma conciliar de 1962-1965. 
reforma eclesiástica representada en la celebración del Concilio Vaticano II (1962-1965), iniciada por el papa Juan XXIII y culminada por su sucesor Pablo VI. Para entender mejor este fenómeno es importante dedicar un espacio a los dos referidos eventos.

\section{La Iglesia católica en el contexto de la Guerra Fría}

Al mencionar una crisis social, política y económica a nivel global como uno de los elementos que tanto afectaban a la población del denominado tercer mundo, incluyendo América Latina, se debe hacer referencia a una serie de modelos políticos y económicos liberales (capitalistas) que proliferaron a raíz de la Segunda Guerra Mundial. A mediados del siglo Xx en Latinoamérica ya había una Iglesia social que entraba más en contacto con la gente, que se involucraba y era más crítica de la realidad como consecuencia de los modelos antes mencionados. Este posicionamiento que se concretaría en importantes eventos en la década de 1960 explica el surgimiento del liberacionismo radical al interior de este organismo históricamente conocido y calificado por su ortodoxia.

Los acontecimientos que caracterizaron a la Segunda Guerra Mundial, además del estremecimiento del mundo por el genocidio con el llamado holocausto, entre otros hechos atroces, dieron lugar a la reconfiguración política de Europa y los efectos que esto trajo a nivel global. El nuevo orden mundial estaba definido en realidad por dos bloques antagónicos, representados por la Unión de Repúblicas Socialistas Soviéticas (URSS) y por Estados Unidos de América (EUA), además del Reino Unido y Francia, tensión que a la postre dio lugar a lo que se conoce como Guerra Fría. 
Estos dos bloques opuestos ideológica y políticamente no sólo contribuyeron a la conformación del nuevo orden mundial, sino a un estado psicológico particular que consistía en la expectativa de que estallara en cualquier momento otra conflagración de grandes alcances. Prueba de ello es que entre las décadas de 1960 y 1980 circulaban rumores que alteraban a los habitantes del mundo, como la llamada "crisis de los misiles", en 1962, o el programa científico de defensa Star Wars, en 1980.

El estado psicológico al que se alude se trataba en realidad de una retórica anticapitalista o anticomunista, según fuera el caso, pero no trascendía de ahí. De hecho, esta dinámica que se quedaba a nivel discursivo es lo que mantenía la paz, porque ambos bloques conciliaban sus intereses reales al generar un equilibrio que impedía la posibilidad de una guerra (Berend, 2013; Hobsbawm, 2014; Judt, 2014), esto significa -como afirma Kramer (1999, p. 540)- que "la Guerra Fría y su estructura bipolar de políticas internacionales de posguerra surgieron de una contienda de ideas desde un conflicto ideológico".

Esta dinámica ideológica de la Guerra Fría se fue diluyendo hasta que llegó a su fin con la caída del sistema soviético y sus Estados satélite. ${ }^{6}$ Sólo así, cuando la URSS y su política perdieron su objetivo antagónico, hubo una transformación global en la

\footnotetext{
6 Existen diversas teorías de por qué colapsó política e ideológicamente el bloque soviético. Kramer propone que, a diferencia de Estados Unidos, la URSS tuvo que imponer su sistema ideológico y una gran presencia militar sobre sus aliados, los "Estados satélite". Pero, también a diferencia de Estados Unidos, en el periodo de terror del estalinismo o de políticas intransigentes como la de Brezhnev, se registró una serie de revueltas constantes entre la "desestalinización" (1953) y la caída del Muro de Berlín (1989), como prueba del desacuerdo y resentimiento popular contra las instituciones soviéticas, así como un sistema político y económico que había colapsado hacía tiempo.
} 
que en apariencia el capitalismo como modelo económico había triunfado (Kramer, 1999, p. 540).

En este escenario polarizado, el llamado tercer mundo no fue tomado en cuenta en la reconfiguración geopolítica. Estados Unidos intentó sostener esta situación con su programa de autodeterminación de los pueblos; con la base democrática de su discurso pensaba otorgar derechos políticos, colectivos e individuales (derecho al sufragio) y que, en el fondo, no era tan diferente a la antinomia liberal que era el leninismo, aunque con términos discursivos como "antiimperialismo" y "construcción del socialismo" (Wallerstein, 2011).

América Latina, sin embargo, actuó en este escenario y al interior de los países generó una tensión entre grupos capitalistas y sectores populares que vivían en condiciones económicas y sociales cada vez más complicadas, y que se inspiraban en la Revolución cubana como una vía para acabar con la opresión y la desigualdad, impulsados por la idea de seguir un camino propio y no regido por las estructuras e intereses de Estados Unidos. Para ello, el ejemplo de la Revolución cubana se materializó con la formación de grupos de guerrillas rurales y urbanas como en Venezuela, Perú o Guatemala.

La reacción de Estados Unidos se manifestó en la puesta en marcha de su iniciativa "Alianza para el progreso" que, en el fondo, pretendía poner un alto a la tendencia antinorteamericana que se propagaba por toda Latinoamérica (Berryman, 2014; Berend, 2013). La tensión que se vivía en esta región del mundo era visible, la desigualdad cada vez mayor, la represión y el apoyo estadounidense a través de la CIA se sentía con más frecuencia y la Iglesia católica de tendencia conservadora también empezaba 
a dividirse, lo que fortalecía un ala de este organismo de inclinación progresista. Pero de esta transformación eclesiástica, en la que la situación política y económica mundial en el contexto de la Guerra Fría influyó sobremanera, hubo otro factor determinante que se abordará a continuación.

\section{La reforma eclesiástica: el Concilio Vaticano II y sus consecuencias}

En América Latina, dos hechos que generaron controversia al interior de la Iglesia católica fueron la situación global de desigualdad social y el Concilio Vaticano II. El primero, como ya se mencionó, causó efecto entre algunos miembros de la Iglesia que ejercieron una práctica pastoral involucrada desde una perspectiva política y más sensible a la realidad del pueblo; en el segundo caso, por tratarse de una reforma con la que por vez primera se abría espacio en la Iglesia para afrontar estos problemas, lo que en otro momento se consideraba radical.

Afirma Berryman que antes del Concilio Vaticano II los católicos tenían como deber permanecer "en estado de gracia y alcanzar el cielo" (Berryman, 2014, p. 20). El cambio que trajo este Concilio fue acentuar más la heterogeneidad de la Iglesia y poner al día el discurso político y la perspectiva de su misión frente al acelerado cambio cultural, social y político que conlleva lo que se concibe como modernidad.

Los obispos latinoamericanos tuvieron poca participación en el Concilio y, por lo tanto, podría asumirse que se trató de un evento desde una óptica europea ajena e insensible a la realidad latinoamericana, pero en este proceso y con la mirada de dos 
sumos pontífices (Juan XXIII y Pablo VI) sí pudo descifrarse y discernir un mensaje ad hoc a los problemas sociales locales. En esta parte de la investigación es importante resaltar dos acciones que produjo el Concilio:

1. Promover el diálogo con el mundo y con las culturas.

2. Inspirar una encíclica, Populorum Progressio (1967), que aborda temas de progreso y desarrollo del tercer mundo, criticando al orden económico internacional, lo que le valdría el calificativo por parte de Estados Unidos de "marxista".

Este Concilio implicó una fuerte ruptura con el viejo orden canónico, lo que provocó una férrea oposición entre varios sectores internos y externos de la Iglesia. Lo que es un hecho es que en su aparente radicalismo, así percibido por diversos grupos de la sociedad y de la jerarquía eclesiástica, el Concilio Vaticano II no promovía la revolución ni la lucha para la liberación del pobre y el oprimido, sino el derecho al bienestar social. Dos documentos importantes de este periodo son las encíclicas papales Pacem in Terris (1963) y Populorum Progressio (1967). Esta última es clara en cuanto a la posición de la Iglesia hacia un movimiento renovador:

[...] la insurrección revolucionaria, salvo en caso de tiranía evidente y prolongada, que atentase gravemente a los derechos fundamentales de la persona y dañase peligrosamente el bien común del país engendra nuevas injusticias, introduce nuevos desequilibrios y provoca nuevas ruinas. No se puede combatir un mal real al precio de un mal mayor (Pablo VI, 1967, párr. 31). 
Pero, de la misma forma, Juan XXIII invoca los derechos del ser humano de tener una vida digna:

En lo relativo al campo de la economía, es evidente que el hombre tiene derecho natural a que se le facilite la posibilidad de trabajar y a la libre iniciativa en el desempeño del trabajo. [...] Pero con estos derechos económicos está ciertamente unido el de exigir tales condiciones de trabajo que no debiliten las energías del cuerpo, ni comprometan la integridad moral, ni dañen el normal desarrollo de la juventud. Por lo que se refiere a la mujer, hay que darle la posibilidad de trabajar en condiciones adecuadas a las exigencias y los deberes de esposa y de madre. [...] De la dignidad de la persona humana nace también el derecho a ejercer las actividades económicas, salvando el sentido de la responsabilidad. Por tanto, no debe silenciarse que ha de retribuirse al trabajador con un salario establecido conforme a las normas de la justicia, y que, por lo mismo, según las posibilidades de la empresa, le permita, tanto a él como a su familia, mantener un género de vida adecuado a la dignidad del hombre. Sobre este punto, nuestro predecesor, de feliz memoria, Pío XII afirma: Al deber de trabajar, impuesto al hombre por la naturaleza, corresponde asimismo un derecho natural en virtud del cual puede pedir, a cambio de su trabajo, lo necesario para la vida propia y de sus hijos. Tan profundamente está mandada por la naturaleza la conservación del hombre (Juan XXIII, 1963, párrs. 18-20).

Con estos elementos que dan una idea de la posición por lo menos desde el Vaticano de esta década de 1960, surge una pregunta sobre el problema: ¿qué es lo que motivaría a asumir posturas más radicales, aunque no necesariamente que indujeran a la 
violencia, por ejemplo, en América Latina? Es aquí donde entra otro evento de suma importancia, que es la CELAM de 1968, como consecuencia de la reforma conciliar.

\section{Conferencia General del Episcopado Latinoamericano} (Medellin, 1968)

La CELAM de 1968 es una síntesis del mensaje conciliar y su interpretación por parte de los jerarcas de la Iglesia. La referida interpretación se basaba en una realidad de desigualdad y marginación latinoamericana; por lo tanto, no es raro asociarla con una situación de revueltas y manifestaciones que, de hecho, se suscitaba más allá de América Latina -Chicago, Praga, París, Tlatelolco, entre otros lugares- y que en su mayoría estaban formadas por la clase trabajadora y por estudiantes que protestaban ante los regímenes de uno u otro orden.

En Medellín se hizo un análisis social de Latinoamérica antes de llegar a reflexiones de tipo teológico. Eso ya significaba de por sí un cambio, lo que algunos círculos conservadores calificarían como con ideas de tinte marxista. Pero más que marxismo, se trataba de una reflexión que pretendía materializarse en una praxis pastoral cuyos principios se basan en la idea de que los individuos son "sujetos de su historia" y de su propio progreso; es decir, consistía en una concepción distinta a la de una revolución como la cubana, con una idea de sublevación que pretendía liberar a los subalternos, más que derrocar exclusivamente al Estado.

La teología de la liberación y la CELAM de 1968 perseguían un objetivo relacionado con frenar la situación de desigualdad que se observaba en el mundo, sobre todo en el denominado 
tercer mundo, pero sus métodos en un plano teórico e intelectual no contemplaban un reconocimiento de la diversidad étnica. Esto le valía críticas que ya se habían expresado en el encuentro de obispos previo a la CELAM, que se llevó a cabo en Melgar, Colombia, en 1968. Ahí el antropólogo Gerardo Reichel-Dolmatoff lo manifestó de la siguiente forma:

¿Qué sucede cuando el misionero penetra en su territorio tribal o a su valle andino e inicia su obra evangelizadora? En primer lugar, el Evangelio no es un factor aislado sino forma parte de un contexto cultural, el de nuestra civilización occidental cristiana. El misionero no solo lleva la palabra de Cristo sino transmite una cultura; se convierte en un agente de nuestra cultura, en un agente de cambio, no solo en un terreno religioso. ¿Cuál es entonces su actitud frente a la otra cultura, frente a lo que aquellos indios han creado a través de esas experiencias milenarias? Obviamente, el misionero quiere introducir un cambio en la vida del aborigen, quiere modificarla, y esa modificación intencional abarca todo un complejo cultural que incluye la vivienda, la economía, la estructura de la familia, la salud, el comercio, el vestido, las herramientas, etc., etc. Se trata, pues, de lo que llaman técnicamente un "cambio cultural dirigido". Sería de esperar entonces que el misionero, antes de tratar de modificar una situación dada, estudiara en detalle esta situación cultural; que tratara de conocerla en lo referente a sus motivaciones, sus procesos y sus metas; que aprendiera el idioma de los indígenas para poder compenetrarse con sus particulares modelos de pensamiento, pues en cualquier otra ocasión, cuando se trata de modificar algo, se estudia lo que se va a modificar. Pero el misionero, frente a la situación de contacto cultural, no siempre actúa así. Aunque tenga cierto interés en conocer 
la cultura indígena, no tiene la formación adecuada que le permitiría sistematizar sus observaciones sobre la vida del indígena. Así pues, en ocasiones, puede llegar a tomar al indio como si fuera un ser sin raciocinio y menosprecia entonces su cultura, como si fuera ésta una mezcla fortuita de crudas supersticiones, creencias infantiles y actitudes erróneas e ilógicas. Rechaza esta obra de arte, este fenómeno tan único del espíritu humano que es una cultura y comienza a imponerse, a cambiar y a modificar. La falla no está en el misionero, sino en nuestra misma cultura; está en el etnocentrismo ciego de nuestra civilización que niega los valores del otro, que niega todo lo que es diferente. Así, los contactos que establece nuestra cultura con las culturas están fundados en una posición a priori: “iLos indios deben aprender todo de nosotros! ¡Nosotros no tenemos que aprender de ellos!” ¡La base del contacto natural es pues una negación, y nada menos que una negación del otro! (Reichel-Dolmatoff, 1972, p. 1140).

El mensaje del Concilio Vaticano II en cuanto a "dialogar" con las otras culturas queda claro que no se realizó de forma inmediata. Los esfuerzos del ala progresista de la Iglesia latinoamericana, que despertaba y discutía sobre la realidad de desigualdad en el mundo, se concentraron al principio en la urgencia de liberar al pueblo oprimido a través de un mensaje y praxis cristianos contra un modelo económico imperial y una historia colonial propia de siglos de existencia.

El pensamiento liberacionista se caracterizaba por ser una opción mediante una pastoral que no estaba preocupada por adoctrinar y llevar la palabra de Dios de forma tradicional a la subalternidad, sino que se interesaba en revertir la situación de pobreza material, la marginación y explotación de los oprimidos 
y pobres, entre los que destacaban afrodescendientes y pueblos indígenas, quienes en su mayoría se concentraban en las zonas más rurales de los Estados latinoamericanos.

Cierto es que la pastoral emanada de este liberacionismo a favor de los sometidos no se había desarrollado al principio como una propuesta de respeto a la diferencia cultural y étnica, a pesar de las críticas que se emitían en textos como el de Reichel-Dolmatoff o en encuentros tan importantes como la Primera Declaración de Barbados (25-30 de enero de 1971), donde también se expuso la responsabilidad de las misiones religiosas de imponer "criterios y patrones ajenos a las sociedades indígenas dominadas, que bajo un manto religioso encubren la explotación económica y humana de las poblaciones aborígenes" (Primera Declaración de Barbados, 1971, p. 2). Pero es un hecho que este ambiente de discusión y crítica que complementaron los resultados de la CELAM de Medellín estableció un punto de partida para el ejercicio de una pastoral distinta y más consciente de las necesidades de cada comunidad, por lo que el reconocimiento de la diversidad sería una de esas características que se anexarían a la nueva pastoral que no contribuiría al etnocidio de antaño.

En el contexto mexicano, la influencia de la teología de la liberación es clara, aunque no podría decirse que se haya llevado a cabo como tal. De hecho, gran parte de los sitios rurales sureños del país se caracterizan por una importante concentración de pueblos indígenas, por lo que el liberacionismo inspiraría movimientos y prácticas pastorales en estos entornos -y en menor medida en medios urbanos-, pero el liberacionismo fue muy diferente al de realidades como la de Brasil, Argentina, Colombia, Ecuador, El Salvador, Nicaragua, Venezuela, entre otros. 
En el estado de Chiapas, con una gran diversidad indígena, empezó a haber una práctica pastoral de liberación, pero pronto se vería complementada y repensada a partir de la complejidad étnica. Ciertamente, ya existía una pastoral indígena de corte asistencialista durante la gestión del obispo Lucio Torreblanca, de la diócesis de San Cristóbal de Las Casas, pero fue con nuevos bríos con los que comenzó su labor en 1960 el obispo Samuel Ruiz García, quien habiendo sido partícipe de la CELAM de 1968, se interesó por la situación de desigualdad social chiapaneca, pero también fue sensible a la compleja diversidad cultural y lingüística de la población rural y urbana de la diócesis.

De la misma forma, el obispo de Tehuantepec, Arturo Lona Reyes (1971-2001), conocido como el "obispo de los pobres", hizo una tarea importante con los pueblos indígenas de la zona del Istmo de Oaxaca. Influido por la teología de la liberación, pero consciente de la diversidad étnica de la zona, luchó a favor del pueblo ante problemas complejos como los asuntos de tierras en la región de los Chimalapas con los zoques, buscó la creación de organismos y uniones campesinas para el comercio justo de café y ajonjolí, fundó escuelas, gestionaba recursos para puentes y clínicas, entre otras obras.

Lona Reyes, junto con Ruiz y el obispo Bartolomé Carrasco Briseño (arzobispo de la diócesis de Antequera en Oaxaca, 19761993) impulsaron una pastoral distinta que si bien tenía como base ayudar a los pobres y luchaba por la defensa de los derechos humanos y de los pueblos indígenas, también pretendía un diálogo con las culturas, es decir, una pastoral indígena.

Lejos se está de hablar de una práctica más cercana a la gobernanza, empezando porque mucho del desarrollo de esta 
actividad sucedía desde la década de 1970, época en la que no existía aún este término ni la práctica per se. Además, existe una postura de la Iglesia "de izquierda" a favor de la liberación de los campesinos y pueblos indígenas, y una renuencia a establecer un diálogo abierto con el Estado - o con las grandes corporaciones transnacionales, si se piensa en la época de mayor impulso después de la caída del Muro de Berlín y el colapso del bloque soviético en 1990-, lo que no significa que no hubiera escenarios en donde pudiera prestarse a conversar; sin embargo, estos espacios se aprovechaban más para la denuncia. Un gran ejemplo de ellos en Chiapas es el Congreso Indígena de 1974, del que se hablará en el siguiente apartado.

\section{La emergencia de la pastoral indígena en México: la Iglesia de los pobres}

La diversidad cultural en América Latina es tan grande como la problemática social relacionada con ella. La mayor parte de los grupos indígenas se encuentra en situación de vulnerabilidad económica, visible en la calidad de sus viviendas, acceso a la educación, a los recursos alimentarios, entre otros; pero también en situación de vulnerabilidad étnica, en gran medida debido al desplazamiento lingüístico y cultural frente a una atmósfera de discriminación y exclusión.

La desigualdad social que entraña el aspecto cultural y económico, además de otros, se ha adjudicado a los modelos neoliberales y, desde antes, a la llamada modernidad, razón por la que el liberacionismo establecía su plataforma discursiva en la 
liberación de los pobres y los oprimidos. La situación se agrava cuando aún en proyectos de liberación y en la práctica de la labor pastoral los misioneros notan que no sólo se trata de liberar a los pobres, sino que éstos tienen una identidad y una cultura específicas que dentro del proceso deben reconocerse y pensarse, por lo tanto, desde la diversidad.

La presencia de grupos indígenas en todo el continente demanda evitar pensar de forma homogénea a la población. Esto significa que una acción pastoral como la que caracteriza a la teología de la liberación debía ser más afín a ciertos contextos latinoamericanos, pues la idea de opción por los pobres y liberación de los oprimidos no reconoce su diferencia étnica, ideológica y cultural.

Como se había insinuado previamente, fueron la intelectualidad de la Iglesia y algunos de sus jerarcas quienes promovieron y apoyaron el posicionamiento progresista que debía asumir la Iglesia latinoamericana, y no los sacerdotes y religiosos(as) comunes (Tahar Chaouch, 2007a y 2007b). De hecho, los primeros acompañaban a la gente, se involucraban en sus problemas y actuaban a partir de las necesidades y la realidad que se experimentaba entre los pobladores oprimidos.

En medio de esta situación no tardó en desarrollarse una pastoral más pragmática e in situ que tuviera algunos tintes étnicos o, por lo menos, que estuviera más abierta a las expresiones culturales de los pueblos indígenas que conforman buena parte de la población oprimida latinoamericana. Lo que se denominaría pastoral indígena, entre las décadas de 1970 y 1980, en México se ejerció en zonas muy específicas, aunque no exclusivamente allí. Quizás el estado de Chiapas es en donde fue más visible, pero 
también ocurrió en los estados de Oaxaca, Veracruz, Chihuahua (Sierra Tarahumara), Yucatán, Quintana Roo, Guerrero, entre otros.

En Chiapas, la zona representativa de la pastoral indígena por su diversidad y densidad poblacional indígena es la diócesis de San Cristóbal de Las Casas. Se tomará este ejemplo para definir, a continuación, las características y el contexto de dicha pastoral.

\section{La pastoral indígena en el sureste mexicano: el caso de Chiapas}

El estado de Chiapas se distingue por una gran diversidad étnica y religiosa. No es de extrañar que con estas condiciones el desarrollo de una acción pastoral, aunque desde la opción del pobre y el oprimido, busque una estructura de adaptación, incluso de asimilación en las culturas. Sin embargo, la noción de una pastoral indígena en esta región del sureste mexicano no tiene su origen en la época de Samuel Ruiz García, en la década de 1970; es decir, aunque con otro enfoque, ya había una acción eclesiástica enfocada en los pueblos indígenas.

Durante la gestión del antecesor de Ruiz, monseñor Lucio Torreblanca (1944-1959) implementó en 1952 una pastoral indígena que aunque aún doctrinaria, estaba organizada y promovía la llegada de distintas órdenes y congregaciones religiosas para participar en un proyecto de pastoral con una firme posición sobre la injusticia hacia los pueblos indígenas y la expansión del reino de Dios, idea inspirada en la encíclica Rerum Ecclesiae del papa Pío XI en 1926, con la que Torreblanca veía a la diócesis como su "territorio de misión" (Morales Bermúdez, 2005, p. 91), para 
lograr poner "en contacto a los gentiles con la verdad evangélica, haciéndola cada día más asequible por medio de los mensajeros evangélicos" (Pío XI, 1926, p. 8).

El peso que tuvo Torreblanca durante su gestión fue grande debido a los efectos posteriores de la llamada desfanatización en la época del maximato; es decir, supo resistir las políticas anticlericales del Estado mexicano de 1920 y 1930, que en muchos casos subsistían aún tiempo después, y sobrellevar la escasez del clero. En esta época la Iglesia católica estaba debilitada y no representaba un peligro significativo para el Estado (Ríos Figueroa, 2002), pero Torreblanca se mantuvo firme hasta que en 1952 comenzó con una propuesta pastoral distinta que el obispo Samuel Ruiz continuaría a partir de 1960 (Morales Bermúdez, 2005; Ríos Figueroa, 2002).

Con la llegada de Samuel Ruiz, sin embargo, no sólo hubo continuidad de la pastoral indígena de Torreblanca, sino que transformó muchos aspectos, esto es, dejó de tener un tono meramente doctrinario para convertirse en una pastoral más pragmática, más influida por el liberacionismo y por una interpretación del mensaje conciliar sobre el diálogo con las culturas, por lo que podría pensarse que se desarrollaba una suerte de pastoral inculturada o encarnada.

Durante la primera década del periodo de Ruiz como obispo, en el mundo se experimentaba un ambiente de gran tensión. La oposición por parte de grupos estudiantiles, trabajadores y el panorama de desigualdad social fue recibida con represiones masivas y una parte de la Iglesia se posicionó a favor de las demandas de una sociedad vulnerable. Pero no todos los miembros de la Iglesia estaban de acuerdo con esta postura más contestataria. 
La escisión que propició esta diferencia de opiniones y posturas entre sacerdotes y altos jerarcas "marcó una crisis dentro de la institución, en particular en los crecientes conflictos internos de autoridad y en la ruptura de la homogeneidad ideológica entre sus hermanos dentro de la misma congregación" (Torres, Fratres Maristae a Scholis/Hermanos Maristas de la Enseñanza, 2008).

En México, el ambiente político se tornaba complicado. Había fuertes cuestionamientos hacia el Estado sobre la situación económica y política, y la Iglesia, en su rama más progresista, empezó a trabajar inspirada en los lineamientos que resultaron de la reflexión de la CELAM de Medellín de 1968, aunque adaptados a las circunstancias y contextos en los que efectuaban su labor. Podría pensarse en las ideas marxistas y revolucionarias con las que la cúpula eclesiástica calificaba esta tarea liberacionista, como expresa Sánchez Sánchez (2007, p. 56):

Por su compromiso social y por la participación de muchos de sus miembros, tanto laicos y laicas, religiosas y religiosos, como presbíteros en las luchas armadas de Centroamérica, se les acusó de practicar la ideología marxista, de ser violentas y de promover la lucha de clases; por su opción por los pobres se les inculpó de ser excluyentes; por su compromiso político por la transformación de las estructuras sociales se les tachó de ser manipuladas por partidos de izquierda.

Más que marxismo, la influencia de la teología de la liberación en México se observa en el pensamiento de Samuel Ruiz, Arturo Lona Reyes, Bartolomé Carrasco, incluyendo a Sergio Méndez Arceo, obispo de Cuernavaca (1952-1982), mucho antes de la práctica 
misionera de los obispos mencionados arriba. Pero, a diferencia de otros contextos latinoamericanos, Lona, Carrasco y sobre todo Ruiz cambiaron su forma de pensar a partir del contacto estrecho que durante su gestión tuvieron con la multietnicidad de las comunidades indígenas de la diócesis y sus problemas.

Así, la diócesis de San Cristóbal de Las Casas actuó ante las necesidades y problemáticas del pueblo, asumiendo una postura de denuncia de la deficiente política agraria y los abusos de poder del Estado. En esto consistía la Iglesia de los pobres: más allá de propagar el mensaje evangélico en su forma doctrinaria y tradicional, se trataba de una acción práctica que frente a la escasez de sacerdotes, reafirma proyectos que se llevaban a cabo desde la época de Torreblanca, como las escuelas de formación catequética para indígenas, de las que los Hermanos Maristas de la Enseñanza se encargarían. ${ }^{7}$ La diferencia es que en las escuelas que se instauraron en la diócesis en la época de Ruiz había procesos de capacitación en oficios, además de la preparación catequética, como recuerda un indígena tojolabal:

R. - Los cursos... con los maristas lo tomé yo. Ahí dormimos, ahí comimos, todo nos daban ellos. Nuestra ropa para trabajar. Leíamos la Biblia como dos clases de dos horas cada una. Luego a trabajar el cuero, la madera. Enseñaban a hacer muebles... de estos que usamos aquí en la casa, a leer. Si no es por el curso

${ }^{7}$ Entre los aspectos más importantes de las escuelas de formación catequética de la época de Lucio Torreblanca estaba llegar a zonas en las que por las condiciones geográficas de la época y la gran cantidad de comunidades indígenas, los catequistas pudieran llevar la palabra de Dios desde sus propias formas y en sus propias palabras. 
ahorita no sabría leer, y luego no es leer, sino entender lo que lee uno.

JV — ¿Cuándo tomó el curso?, ¿dónde?

R. - Pu's yo tenía como veinte. Ahurita tengo setentaiuno, creo.

Era nuevita la escuela allá en San Cristóbal y estuvimos seis mese. Luego me regresé a la comunida’ y empecé a dar catecismo. Y así asistía a cursos de... pu's como de actualización y así hasta que era candidato a diácono, no'más que ya después Roma lo prohibió y ya no pude ser diácono (Ramiro, 2011).

No obstante, algunos eventos que transformaron de forma más radical esta pastoral indígena fueron una evaluación del ministerio catequético en 1968 en San Cristóbal de Las Casas, un congreso realizado en 1974 en esa ciudad y el Primer Sínodo Diocesano de 1975. Para comprender mejor su importancia es necesario dar espacio a cada uno.

En un contexto que antecede a estos eventos, la instauración de escuelas de catequistas desempeñó un papel destacado, como expresó Ramiro, indígena tojolabal entrevistado en 2011. La importancia no radicó sólo en la formación académica y de oficios, sino que para la diócesis implicó un contacto estrecho con la diversidad étnica. Esto dio pie a la transformación de cánones institucionales, pero también a la comprensión de formas de vivir y ver el mundo tan diferente a la cultura "occidental". Se logró un proceso de sensibilización hacia las maneras de pensar y los problemas de la gente, es decir, ya no se trataba sólo de religión, sino de una conversión que llevó a la diócesis y a los agentes de pastoral a "caminar con los pobres en sus luchas por una vida digna" (Kovic, 2005, p. 12). 
Ante la sospecha por parte de la Iglesia en Roma hacia estas labores en América Latina, como las CEB, por asociarlas con la teología de la liberación, cuestionaba abiertamente el trabajo que se realizaba. Samuel Ruiz respondió a todas estas inquietudes con firmeza:

Fue la inmersión de la vida. Separábamos en grupos a los indígenas que estaban en la escuela de catequistas y les decíamos: "A ver, hermano, tú con tu grupo van a interpretar cómo creen que ha sido la historia de ustedes con su entendimiento de Dios. Con sus tradiciones, como ustedes lo han visto, así prepárenlo. Y ustedes vean cómo lo van a interpretar. Con silencio, con palabras. Como a ustedes se les ocurra. Esa es la historia de ustedes". Y a otro grupo: "A ver, hermanos, ustedes van a interpretar lo que saben de la Biblia". Y a un tercer grupo: "Ustedes van a interpretar cómo ven el proceso catequístico" (Fazio, 1994, p. 79).

En la respuesta de Ruiz se observa una pastoral en la que el individuo es sujeto de su propia historia, en la que se le enseña a ser independiente y libre, bajo los preceptos de un mensaje bíblico. Se trata de lo que se denomina catequesis integradora, pero en esta atmósfera surgió un evento inesperado ante los ojos de los agentes de pastoral, de los colaboradores de la diócesis y del propio Samuel Ruiz, después de una evaluación del ministerio catequético en 1968: el Congreso Indígena en San Cristóbal de Las Casas, en 1974.

Previamente hubo una evaluación del ministerio catequético en 1968, de la que destaca el testimonio del dominico Pablo Iribarren, quien expresó que los catequistas indígenas formados 
durante la década de 1960 advertían que la Iglesia y la palabra de Dios contenían el mensaje para salvar sus almas, pero que hacía falta saber cómo salvar sus cuerpos, pues padecían hambre y pobreza material (De Vos, 1997; Estrada, 2004). ${ }^{8}$

Con estos antecedentes se celebra el Congreso Indígena en una época en la que aún subsistían terratenientes, a pesar del reparto agrario, y que manifestaban un gran descontento con el gobierno de Luis Echeverría Álvarez por restarles privilegios con la renovación de la reforma agraria de 1971, que establecía que los ejidos se unieran o formaran nuevas comunidades para recibir un mayor apoyo a través de insumos subsidiados y tasas preferenciales de crédito (Harvey, 2001).

Así, el entonces gobernador de Chiapas, Manuel Velasco Suárez, convocó a un congreso integrado en donde estarían presentes varios representantes de los pueblos indígenas, para conmemorar el quinto centenario del nacimiento de Fray Bartolomé de Las Casas, en octubre de 1974, asignando como responsable de organizar el evento al obispo Ruiz.

La diócesis aprovechó el espacio para invitar a abogados, maestros y estudiantes a fin de que brindaran asesoría y apoyo en la

${ }^{8}$ Sobre la evaluación de ministerio catequético, señala el ex marista y teólogo de la liberación que hubo tres preguntas principales que los ancianos hicieron al obispo y a los religiosos. La primera consiste en lo que Pablo Iribarren señala en su testimonio. La segunda con la semilla de la palabra de Dios, de la que tanto se hablaba en Vaticano II, preguntaban quién tenía esa semilla, cómo se podía sembrar y cultivar, y si sólo los obispos, los sacerdotes o los religiosos la poseían. La tercera pregunta tenía relación con por qué se dicen hermanos. Ellos saben que los misioneros son hermanos porque se han entregado, pero la pregunta va dirigida a la temporalidad; es decir, por cuánto tiempo ellos tendrán que llamarles hermanos o, en otras palabras, por cuánto tiempo ellos estarán presentes ahí. Después de esto, Samuel Ruiz concluyó que eran los misioneros quienes debían convertirse y no ellos (los indígenas) (Vargas, 2012). 
coordinación de cursos en materia agraria en el marco del evento. También destacó la presencia de representantes y líderes tsotsiles, tseltales, ch'oles y tojolabales que usaron el foro para expresar y denunciar la situación de legalización de tierras comunales y ejidales, las invasiones de tierra por los rancheros, la corrupción de los funcionarios del Departamento de Asuntos Agrarios y Colonización, pues exigían pagos indebidos por cada trámite del proceso de solicitud de tierras y amenazaban con abandonar los casos de los campesinos que no podían pagar. Se exigió respeto al Código Federal del Trabajo respecto del salario mínimo, se denunciaba el abuso de los intermediarios que también controlaban el transporte y el crédito, pero lo más interesante del encuentro fue que demandaban que se les impartiera educación en sus idiomas y la defensa de sus culturas indígenas (Harvey, 2001).

Los resultados de este Congreso no fueron del agrado de las autoridades, pero tuvo un impacto muy importante en la diócesis y los pueblos indígenas de Chiapas. Fortaleció las iniciativas de uniones ejidales, organizaciones campesinas y una lucha agraria mejor orientada con el apoyo de agentes externos, como estudiantes, maestros, abogados, que compartían o venían de la experiencia de eventos de importancia en el país, como los movimientos estudiantiles del 68. Quizá uno de los ejemplos más representativos de esto fue la creación de la Unión Ejidal Quiptic Ta Lecubtesel, antecedente de la Unión de Uniones de Las Cañadas.

En la diócesis de San Cristóbal de Las Casas y sus colaboradores este Congreso también generó mayor compromiso social con los pueblos indígenas, pero también un mayor reconocimiento y respeto hacia la diversidad cultural, es decir, una conciencia étnica en tanto característica y directriz fundamental en la puesta en 
marcha de una pastoral indígena, cuyas nociones fundamentales se trabajaban desde 1965, cuando se creó el Consejo Diocesano Pastoral orientado a una Iglesia Autóctona (Estrada, 2004) y con la evaluación del ministerio catequético tres años después.

Cabe señalar que destacó la labor de una sociedad que empezaba a tomar espacios que habían sido dominados por otros grupos o actores que pertenecían a otro estatus. Es decir, jerarcas eclesiásticos, autoridades municipales y gubernamentales y otro tipo de líderes. A pesar de que Samuel Ruiz era una figura importante en la organización de este encuentro, destacó la voz de los pueblos indígenas, participación que podría decirse representó a la sociedad civil.

La nueva catequesis de integración que se proponía después de las reflexiones vertidas en estos eventos debía partir de los catequistas indígenas como integrantes y como una suerte de difusores catequéticos de la diócesis en sus comunidades de origen, para que tomaran la palabra de Dios y la impartieran entre los suyos, pero desde su reflexión y comprensión de ese mensaje evangélico. Con la nueva catequesis de integración se pretendía que las comunidades indígenas dejaran de ser sólo receptoras del mensaje bíblico y participaran también en "la reflexión sobre la realidad y descubrimiento de los mecanismos de explotación" (Leyva, 2002, p. 392).

De esta manera, los cursos de catequistas se organizaron con la nueva catequesis de integración que, además, resolvían el problema de la escasez sacerdotal y contribuían con una lógica discursiva del Concilio Vaticano II al diálogo intercultural y a sumar a los indígenas a la estructura de la diócesis, mediante una figura que poco tiempo después se pondría en marcha: el 
diaconado. Con esto también se empezaba a romper la labor pastoral más asistencialista, poco a poco se dejaba de ver a los indígenas como menores de edad.

El tercer y último evento de importancia que aportó a las bases de una pastoral indígena fue el Primer Sínodo Diocesano en el que, además de la temática anterior y de la catequesis de integración, sacerdotes, religiosos y catequistas (indígenas) discutieron y formularon un plan de acción a partir de dos ejes en los que debía basarse la tarea pastoral: 1) el compromiso de trabajar con el pobre y 2) apoyar en la formación de una Iglesia autóctona (Kovic, 2005). Por lo tanto, los agentes de pastoral debían actuar situándose en el espacio geográfico de sus destinatarios y ser, además, parte de un proyecto de refundación de una Iglesia primitiva para restaurar el reino de Dios, es decir, crear una Iglesia autóctona.

La idea de emprender una pastoral indígena desde esta perspectiva tenía muchas carencias aún. El territorio era muy amplio para poder abarcarlo y la formación de catequistas indígenas requería algún tiempo para ver resultados pronto. El liberacionismo en Chiapas ya no tenía un tono de lucha revolucionaria con el uso de la fuerza, sino con una óptica por medio de la transformación de la labor pastoral y de la Iglesia misma en una que se asimilara en las culturas y que a partir de la diversidad de situaciones y problemáticas analizara la realidad, buscara alternativas para mejorar la economía de la gente y rompiera con la dependencia del Estado y sus programas asistencialistas.

Esto conllevó muchos debates que aún hoy tienen lugar y aunque en esta época de finales de los años setenta y principios de los ochenta no se utilizaban neologismos como inculturación, 
ya comenzaba a ponerse una serie de bases para la práctica y reflexión entre-culturas ecuménica, de diálogo y, por lo tanto, de liberación.

A lo largo de 1980 y 1990, mientras Centroamérica -en especial El Salvador y Nicaragua- experimentaba una situación política compleja y violenta en donde la teología de la liberación tenía un papel fundamental en la formación de campesinos y en la lucha por la liberación del pueblo, en Chiapas y en gran medida también en Guatemala se apostaba más por crear una Iglesia autóctona, esto es, una Iglesia revestida de los rasgos culturales, de la cosmovisión y la fe de los pueblos indígenas, con la diversidad que eso implicaba. La praxis para alcanzar la Iglesia autóctona comenzaría por una reflexión de fe o teología conocida precisamente como inculturación, que a continuación se explicará.

\section{La teología de la inculturación o encarnación del evangelio}

La Iglesia católica ha buscado durante muchos siglos:

[...] lograr la homogeneización cultural [religiosa] y de las sociedades [en lo religioso], lo cual se refleja en el intento de la Iglesia por establecer un lenguaje único y universal en la oración y la liturgia, llevar a cabo rituales estandarizados y proveer de una educación religiosa uniforme por todo el mundo (Theije \& Mariz, 2008, p. 33). 
Sin embargo, en un proceso casi natural la Iglesia también ha debido adaptarse a los tiempos y a las culturas, como ya se ha expresado, con esta suerte de aggiornamento que implicó el Concilio Vaticano II, es decir, "dialogar con otras culturas y respetar la diversidad cultural y las reformas locales de expresión, al menos en un nivel discursivo" (Theije \& Mariz, 2008, p. 34), sobre todo, en contextos de gran pluralidad en que prevalece el ámbito rural.

Esta forma de adaptación por parte de la Iglesia católica posconciliar es parte de lo que se conoce como inculturación y la política o modelo que sigue para lograrla se denomina teología de la inculturación, esto significa una reflexión acerca de la manera en que se debe presentar el mensaje evangélico que es de corte universal, a través del evangelio, con la finalidad de que sea comprendido y experimentado o vivido en todas las culturas con los símbolos particulares de éstas (Marzal, 2002). Por esta razón, los agentes de pastoral o misioneros deben insertarse en el mundo social y cultural de aquellos a quienes son enviados (Marzal, 2002).

En este proceso de inserción y de inculturación existen tres tipos de actores y discursos:

1. Los intelectuales y teólogos que pertenecen al clero.

2. Los agentes de pastoral o líderes militantes, que son los actores principales en la renovación ideológica y teológica de la liturgia y práctica religiosa.

3. Los seguidores o miembros ordinarios de cada movimiento (Theije \& Mariz, 2008). 
No obstante, al igual que en la teología de la liberación, debe comprenderse que en la noción de inculturación existe un lado teórico generado por la intelectualidad, que dista del concepto de inculturación en la praxis que conforman los agentes de pastoral o misioneros, quienes están en contacto constante con los grupos indígenas.

Desde la década de 1970, como ya se dijo antes, la pastoral indígena cobraba nuevos bríos influidos por el liberacionismo. Es en 1990 cuando los agentes de pastoral no sólo tenían la idea de liberar al pobre, sino adaptarse a su cultura, encarnarse o propiciar una asimilación recíproca cultural y de cosmovisiones a través de la palabra de Dios. Es entonces cuando se asume que la pastoral indígena se fundamenta en una teología de la inculturación.

Empero, la inculturación como tal no se trata de una acción o postura de la década de 1990; en realidad siempre ha estado presente en la Iglesia católica. El cristianismo ha buscado a través de los siglos acomodarse o ajustarse a su entorno a través de incorporar estructuras y principios contemporáneos, así como al adecuarse a los avances tecnológicos y científicos; "se intenta cambiar el proteccionismo, la Iglesia monolítica y triunfalista por una Iglesia más abierta que reconoce su propia necesidad de reforma continua y comprometida con una mayor democracia, ecumenismo y pluralismo" (Seidler, 1986, p. 854).

La inculturación no es una adaptación canónica y dogmática a las formas culturales de un pueblo diferente de la cultura de donde surge el catolicismo, es decir, Europa occidental. La inculturación como término surge en el seno de una teología cristiana no católica en 1970 y alude a una época incluso protocristiana; dicho de otro modo, a un tiempo en que el cristianismo aún no se 
forjaba, si se considera que esta doctrina se conformó posterior a la muerte de Cristo y se esparció el mensaje interpretado por sus seguidores.

El significado de inculturación, entonces, tiene que ver con un paradigma relacionado con Jesucristo que, siendo hijo de Dios nació, socializó y adquirió una cultura humana a lo largo de su vida. Estas características son justo lo que se conoce como la encarnación del Verbo. A partir de esta idea, al remitirse a la primera mitad de la década de 1960, se puede observar el término encarnación para definir en este caso la inserción del mensaje cristiano en la diversidad cultural como alude $A d$ Gentes en el Concilio Vaticano II.

La Iglesia católica posconciliar expresa la necesidad de contextualizarse y ajustarse a la sociedad contemporánea y al mundo moderno, lo que comprende a la diversidad cultural. Así, ambos términos, contextualización y adaptación, implican una actualización y adecuación a las circunstancias de distinta naturaleza, ya sea política, cultural, económica, ideológica, entre otras, pero también a las costumbres, tradiciones y cosmovisión de los pueblos en donde la Iglesia está presente, en donde pretende actuar para lograr una liberación tanto de la pobreza material y la marginación, como de la injusticia social y la opresión política. Sin embargo, con el tiempo la Iglesia y los agentes de pastoral observaron que no era suficiente la adaptación, sino que debían fundirse, asimilarse e involucrarse en la diversidad cultural, esto es, encarnarse en las culturas.

En este orden de ideas, la inculturación no consiste sólo de un concepto o de una reflexión de fe (teología), sino de acciones e interacción. Al respecto, Anscar Chupungco explica 
que la inculturación se trata de "un proceso propio y continuo y propio para cada país o región en donde se ha sembrado la fe" (Chupungco, 2005, p. 31). Por su parte, Aylward Shorter señala que la inculturación "no es [sólo] la inserción del mensaje cristiano en una cultura no cristiana" (Shorter, 1988, p. 11) y que la fe cristiana no puede existir en una forma cultural, pues "la fe cristiana no existe en un espacio neutral o fuera de la cultura, sino que es expresado y materializado a través de la cultura" (Shorter, 1988, p. 13).

La postura del jesuita Aylward Shorter acerca de la inculturación se refiere a que ésta no es precisamente una transmisión o transferencia del significado religioso o evangelización de una cultura dominante sobre otra, ya que la misión de evangelizar se realiza a través de la interacción histórica de las culturas. No obstante, sí afirma que los misioneros llegan a una situación de aculturación ${ }^{9}$ y tratan de adaptar el mensaje cristiano en busca de expresiones locales para que el mensaje sea entendido, es decir, se identifican elementos de la cultura local para comunicar el significado y capacitar a sus interlocutores, y así facilitar el proceso de inculturación (Shorter, 1988, p. 14).

La Iglesia católica concibe la inculturación de una forma un poco distinta, pues se trata de una experiencia desde las culturas, es decir, el evangelio es el que se incultura, aunque en la praxis los propios misioneros asumen y afirman que ellos también se

${ }^{9}$ Para Gonzalo Aguirre Beltrán, aculturación refiere a cuando "grupos de individuos de diferentes culturas entran en un contacto continuo y de primera mano, con cambios subsecuentes en los patrones culturales originales de uno o ambos grupos" (Aguirre Beltrán, 1992, p. 14). 
inculturan. En cualquier caso, el proceso de inculturación sucede a partir de "descontextualizar las narrativas cristianas de sus referentes culturales de occidente y reposicionarlas dentro de un 'telos' [indígena]" (Garrard-Burnett, 2005, pp. 49-50).

La inculturación, más que un proceso de asimilación recíproca natural en una interacción cultural, en el ámbito religioso parece tratarse de una serie de lineamientos y una perspectiva desde Roma, es decir, una teología de la inculturación, por el hecho de ser una práctica planteada desde la Iglesia, razón por la que Garrard-Burnett la define como una mezcla de prácticas religiosas indígenas y cristianas en una suerte de catolicismo folk (Garrad-Burnett, 2005). Sin embargo, pese a este planteamiento de un deber ser y un deber proceder, se trata de una acción pastoral en la que con el tiempo y en la práctica -más allá de si se ha tratado como una forma de folclorizar el cristianismo y reinterpretar la cultura del otro- genera un proceso de inserción por parte del misionero.

La fe del misionero o agente de pastoral y los elementos religiosos y cultuales de las culturas a las que se dirige su acción de evangelización genera lo que se concibe como sincretismo, esto quiere decir que la inculturación implica adentrarse en la cultura del otro para insertar o sembrar un mensaje que desde una perspectiva teológica no tiene cultura, pero en la práctica y desde una mirada antropológica sí la tiene; por lo tanto, el sincretismo explicaría medianamente el fenómeno, pues éste implica la presencia de ambas culturas: la de un mensaje cristiano que es más europeo y la de una sociedad indígena en particular, pero señala Marzal (2002) que lo anterior conlleva necesariamente y de forma recíproca una suerte de reinterpretación religiosa en el 
sentido de agregar elementos religiosos y culturales no cristianos al rito cristiano.

Un aspecto más a considerar acerca de la inculturación es su carácter utópico, toda vez que se trata de un proceso con una meta que aún no se ha alcanzado, razón por la que religiosos como Jesús Tapuerca (2002) y Paulo Suess (1993) consideran que "no se puede hablar de un logro por parte de la Iglesia católica en cuanto a la inculturación, ya que esta institución se encuentra muy atada a una cultura patrona o universal" (Suess, 1993, p. 156). De hecho, el propio Suess hace una fuerte crítica a la Iglesia que se presenta con vestiduras culturales occidentales, pues así "permanece extranjera, desencarnada y con un discurso que no llega a los corazones de los pueblos" (Suess, 1993, p. 160).

El teólogo Pablo Richard aclara que en esta dinámica de inculturación no se busca oponerse a la oficialidad de la Iglesia, sino "la construcción de la universalidad a partir de unidades pequeñas que estén fortalecidas en su identidad y sean capaces de articularse entre sí en un horizonte que permita transformaciones globales" (Richard, 1998, pp. 58-59). Esto significa que con la inculturación la Iglesia católica persigue ser universal al fomentar la comunidad en el dogma y la fe cristiana, pero también plural porque a través de la encarnación o inculturación del evangelio en las comunidades, por medio de una teología la inculturación, trata de desterrar todos esos ropajes culturales occidentales, como las conductas, actitudes, valores, entre otros, que pretenden recubrir y anular las formas culturales autóctonas, así como impedir el desarrollo de la identidad propia.

Ahora bien, la forma como se puede pensar la inculturación en una praxis pastoral in situ dista mucho de los elementos teóricos. 
Para la antropóloga Pilar Gil Tébar (1997), mientras la Iglesia dentro de esta dinámica de inculturación desee constituir y consolidar una Iglesia autóctona arraigada en cada uno de los diferentes grupos indígenas, le será indispensable, entonces, que los agentes de pastoral conozcan a profundidad el modus vivendi de los pueblos indígenas y, en seguida, que entiendan y asuman que la presencia de Dios no está en el rito cristiano, sino en la población, la cultura, las creencias y manifestaciones comunitarias indígenas.

Así, la teología de la inculturación empieza a percibirse distinta de la de su acepción más institucional, por la tanto, más ad hoc a una pastoral indígena, lo que implica una praxis en la interculturalidad. Esto merece atención especial, por lo que a continuación se desarrollará el tema de lo que he concebido como una inculturación de la praxis.

\section{Inculturarse en la praxis}

En el ejercicio etnográfico realizado tanto en Chiapas como Guatemala, la comprensión de la inculturación en su significado conceptual y a la vez pragmático es complicada, no sólo por el contenido teológico, sino por su subjetividad. Para hablar de inculturación en la praxis debe entenderse como una experiencia o vivencia de ésta, lo que implica un proceso de varios años, incluso décadas. Sin embargo, la inculturación también tiene una naturaleza canónica e institucionalizada que define desde sus políticas el proceso a seguir, lo que en estricto sentido y contradictoriamente impide la inculturación. Para entenderlo mejor, un misionero diocesano de Comitán, Chiapas, lo explicó en entrevista más claramente: 
La política de la Iglesia siempre han sido los cambios, que continuamente hay cambios, pero como yo te digo para poder nativizarse requiere años. Se requiere mucho tiempo. ¿Tú crees... con tres, cuatro, cinco años, cambio; tres, cuatro, cinco, cambio, se puede lograr esto? No. Eso fue uno de los problemas aquí en la región. La cuestión está en que, en el periodo de 13 años, pasan aquí en la región seis sacerdotes. ¡En 13 años! ¿Tú crees que se pueda lograr? Y es así en general. Con este tipo de políticas no se puede porque esto significa años (Castillo, entrevista, 2008).

Las palabras de este sacerdote expresan una fuerte crítica al proceder de la Iglesia, pues la inculturación requiere de mucho tiempo para poder discernir los rasgos culturales y la cosmovisión de la sociedad con la que los misioneros trabajan, y viceversa, pero para la Iglesia la temporalidad es un problema, ya por la escasez sacerdotal que exige que deban dirigirse a otras zonas en donde deben cumplir ciertas tareas, ya por una estrategia administrativa. Para algunas misiones como la de los Hermanos Maristas en Chiapas (en Comitán de Domínguez y en Pico de Oro, Marqués de Comillas), una regla que debe cumplirse es que un agente de pastoral que administra la misión cumpla con un tiempo determinado de servicio en ese lugar y después no sólo cambie de funciones, sino que inicie otra labor misionera en otro sitio.

Puede haber muchos motivos para ello. El coordinador de la Misión de Guadalupe en Chiapas, en 2008, Juan Carlos Robles, FMS, explicaba que la lógica de no permanecer en el lugar a cargo de la misión durante tanto tiempo obedece a que debe evitarse que se "echen raíces" o se hagan cotos de poder. Para los 
maristas, el tiempo promedio de permanencia es de seis años. De hecho, el anterior director o coordinador de la misión, Gerardo Torres Estrada FMS, al considerar el tiempo que debe tener un agente de pastoral en el proceso de inculturación, hablaba de un año de observación y escucha para comprender la cultura indígena y las problemáticas de la comunidad, y luego empezar a proponer o participar en un plan de trabajo (Torres, FMS, comunicación personal, 27 de noviembre de 2008).

En el caso del sacerdote diocesano entrevistado en ese mismo año, llevaba casi 40 años en el mismo cargo y su crítica se centra en la idea de que si no se permanece mucho tiempo en el lugar, no sólo no se pueden comprender los intereses y la cultura de la sociedad con la que se convive, sino que no puede haber una inculturación, no se puede formar una Iglesia revestida de la cultura indígena y mestiza, en esa suerte de fusión y/o asimilación que significa la inculturación.

La inculturación requiere del tiempo al que alude el sacerdote Ramón Castillo, a sabiendas del peligro de generar cotos de poder, como advierten los maristas Juan Carlos y Gerardo, por el simple hecho de consistir en un proceso de transformación, de inserción sociocultural y de comprender la cosmovisión del otro. El propio ex director de la Misión de Guadalupe de los Hermanos Maristas, Gerardo Torres, define desde su experiencia y su práctica pastoral a la inculturación:

[...] inculturación es que realmente te metes en la cultura, aprendes la cultura, conoces la cultura, ves la manera como mira la cultura y a partir de ahí empiezas a dialogar con la cultura [...] Cuando ya eres capaz de entender cómo entiende 
el mundo el indígena, entonces ya puedes dar propuestas desde esa visión porque si no estás imponiendo una manera de y una forma de trabajar desde afuera... yo tardé tres, cuatro años para ir entendiendo muchas cosas y en este momento me siguen cayendo veintes $[\ldots]$ pero en dos, tres, cuatro, cinco años, apenas empiezas a entender muchas cosas (Torres, FMS, comunicación personal, 27 de noviembre de 2008).

Una de las preocupaciones que reflejan los entrevistados es el tiempo necesario para comprender los rasgos culturales y la cosmovisión de los pueblos indígenas con los que trabajan. Hacen hincapié en no interferir o no imponer su pensamiento y criterios occidentales o exógenos. Pero, además del tiempo, implica una presencia constante de los agentes de pastoral en las comunidades, lo que es todo un reto, pues la escasez de colaboradores, aun laicos, es muy visible en algunas zonas.

La inculturación en la praxis no sólo se trata - como versa en su acepción institucional o teórico-teológica- de revestirse del ropaje vernáculo en una suerte de adaptación, sino en conocer al indígena, su cosmovisión y su manera de vivir, lo que no será posible haciendo visitas esporádicas, más bien en una dinámica paulina de hacerse a la cultura de ellos y ser uno con ellos, ${ }^{10}$ es decir, seguir el ejemplo de Cristo, hijo de Dios, que no sólo se adaptó a la cultura y sociedad humana, sino que nació y creció entre

${ }^{10}$ En palabras de algunos agentes de pastoral, algo frecuente es nativizarse. Este adjetivo es una idealización que pretende no sólo ser parte de la comunidad del otro, sino ser parte del otro, pensar como él, tener su manera de ver el mundo. Es un ideal que está muy relacionado con la meta de la inculturación, pero eso no implica (y ellos no afirman) haberlo logrado aún. 
humanos y como humano, esto es, se encarnó y por lo tanto se inculturó.

Mucho de lo anterior se manifiesta en la propia historia de América Latina desde la primera etapa de evangelización, en la denominada Conquista Espiritual que usó estrategias pedagógicas como elementos pictográficos o representaciones teatrales de escenas bíblicas, además del uso de la fuerza y la violencia no pocas veces desmedida en contra de los nativos (Ricard, 2002) hasta un discernimiento, incluso asimilación, de la cultura indígena por parte de los misioneros y de la cultura de los misioneros por parte de los indígenas. En este contexto, podría decirse, se construía una Iglesia particular y a esto alude el Concilio Vaticano II cuando se refiere a las iglesias locales, que después se denominarán iglesias autóctonas.

La Iglesia autóctona es un efecto claro de la inculturación o una parte de ella. Es una Iglesia que sin estar separada de la católica y sus cánones está revestida de la cultura y cosmovisión de la gente local. ${ }^{11}$ Sin embargo, asumir una mecánica de asimilación recíproca como definición y como praxis de la inculturación es negar que persiste una parte colonialista o dominante de la Iglesia. Incluso los propios agentes de pastoral saben el reto que

${ }^{11}$ La Iglesia local o autóctona que pretende alcanzarse a través de la inculturación no es creando iglesias independientes de pueblos culturalmente salvos y político-religiosamente desarticulados, ni una desarticulación de la macroestructura, sino que se exige la participación decisiva de los actores o sujetos de las respectivas culturas destinatarias, en comunión con el conjunto de iglesias que componen la Iglesia Universal (Suess, 1993). Esto habla del carácter universal de la Iglesia católica, pero también del anhelo de crear iglesias independientes de la hegemonía occidental que impone la macroestructura que forma la Iglesia católica. 
implica deshacerse de esas "vestiduras" colonialistas, razón por la cual una definición más precisa de inculturación es:

[...] el esfuerzo de la iglesia (católica) por encarnar el Mensaje evangélico cristiano en todas las culturas de la humanidad, y hacerlo de tal forma que por dicha inculturación la fe cristiana logre expresar toda la riqueza revelada en Cristo, aprovechando todo lo bueno de las culturas, al mismo tiempo que se da como un proceso de evangelización de las culturas, por medio del cual éstas se mejoran y enriquecen la experiencia cristiana (Fornet-Betancourt, 2005, párr. 20).

A esta noción utópica de la inculturación - no sólo en los testimonios de los agentes de pastoral entrevistados sino en la opinión de muchos otros misioneros en Comitán u Ocosingo, Chiapas; Totonicapán, Guatemala, o Riobamba, Ecuador, con los que se ha tenido contacto a lo largo de los años 2000-2019- se suma la perspectiva de líderes indígenas que han trabajado en algún momento con los agentes de pastoral. Es de destacar las palabras de "Eduardo", ${ }^{12}$ un guía espiritual quiché de Santa María Chiquimula, Guatemala, acerca de la inculturación:

En un matrimonio quiché, por ejemplo, según el derecho canónico, lo avala como un... ya es un matrimonio oficial, o sea, puede estar nada más un diácono de testigo y ya están casados por la

\footnotetext{
12 Este líder quiché, Eduardo León, es un sacerdote maya, es decir, de la religión o espi-
ritualidad maya, que ha trabajado de cerca con los jesuitas durante 18 años en la misión ritualidad maya, que ha trabajado de cerca con los jesuitas durante 18 años en la misión de Santa María Chiquimula, en el denominado departamento de inculturación.

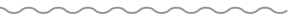


Iglesia si lo desea esta familia. Entonces, claro, ya hay ahora... lo que hacen el rito indígena, el matrimonio propiamente indígena y luego van a la Iglesia y entonces el camino de inculturación es como que este rito ya estuvo, ya no tiene que ir a la Iglesia, entonces la gente se ahorra todo el gasto que va a hacer del matrimonio (Eduardo, comunicación personal, 2008).

Es interesante esta expresión que alude a un matrimonio que se celebra a la usanza quiché y es aceptado por la Iglesia católica, pues aunque no sea un ritual cristiano como tal, se respeta el significado y usos quichés, ya que en esencia el significado común es el mismo entre cristianismo y religión maya. La Iglesia católica, así como la espiritualidad maya, han vivido un proceso de inculturación. Ésta no proviene de los indígenas, sino para un indígena como Eduardo, sucede desde la Iglesia que "entra al corazón de los pueblos [...] la inculturación se reduce más a un sector y el que hace el proceso de inculturación no es el indígena, sino el caxlán (mestizo)" (Valtierra Zamudio, 2009, p. 64).

En este orden de ideas, el enfoque en contextos predominantemente indígenas, como la diócesis de San Cristóbal de Las Casas, la de Tehuantepec, Riobamba, la Arquidiócesis de los Altos Quetzaltenango-Totonicapán, entre otras, ha pasado por una transformación y acomodación más de corte asistencialista, que va del liberacionismo de la década de 1960 y 1970 a un integracionismo desde la década de 1980, y con mayor fuerza en 1990 y 2000, en el que el indígena es concebido como parte de la Iglesia, se le hace partícipe y ella se enraíza en las culturas indígenas. 
En esas décadas, y aún en la actualidad, paralela a la teología de la inculturación, la pastoral indígena implicaba algo más que encarnarse en las culturas, pues había una necesidad de reconocer la diversidad religiosa, que desde la perspectiva cristiana puede entenderse como ecumenismo. El cristianismo parte de la idea de que el mensaje evangélico no está contaminado o determinado por una cultura en específico, sino abierto a todas las culturas.

El fenómeno sociorreligioso que se registra al tiempo del proceso de inculturación en la práctica pastoral es una suerte de reconocimiento y síntesis, a la vez, de la religiosidad indígena. Se trata de la teología india, tema que se abordará con mayor profundidad en el siguiente capítulo, pero que genera un escenario polémico, pues muchos de los elementos vertidos en la teología india tienen que ver con una reinterpretación de las religiones autóctonas y su inserción en el culto cristiano. 


\section{CAPÍTULO 2}

\section{HAGIA UNA PASTORAL GON ROSTRO INDÍGENA}

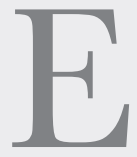

n el capítulo anterior se hizo un recorrido histórico y teórico acerca de cómo fue evolucionando la pastoral indígena. Su paso por una época influida por las ideas revolucionarias latinoamericanas, con la intención de optar por el pobre y liberar al oprimido, así como buscar después un discernimiento y encarnarse en la cultura del otro, lo que implica necesariamente pensar y analizar la cultura de la alteridad y su religiosidad.

Al respecto, la inculturación no es sólo pensar en una adaptación de la Iglesia católica o de los agentes de pastoral católicos a las formas de vida autóctonas, ni pensar en una adaptación del evangelio a ellas, sino comprender la cultura del otro y cómo este otro se asimila a la cultura eclesiástica.

En un ambiente de respeto a la diferencia étnica y en una dinámica de diálogo con las culturas, la noción de ecumenismo es importante en la actividad pastoral; sin embargo, lo que implica el respeto a la cosmovisión y religiosidad étnicas va más allá de lo ecuménico, pues requiere analizar y comprender esa perspectiva religiosa distinta al cristianismo. Por esa razón, lo que podría concebirse como una pastoral renovada tiene su origen en la fuerza de la idea de una teología que conlleva este proceso de inculturación, de ecumenismo y de liberacionismo, es decir, una 
teología india o teologías indias que cobrarían fuerza, sobre todo, entre las décadas de 1980 y 1990 hasta la fecha.

En este capítulo el enfoque estará en la definición, análisis y exposición de la noción que se tiene de las llamadas teologías indias, a partir de experiencias etnográficas del sureste de México, para entender la base importante de una pastoral que reconoce la cultura del otro en contextos indígenas, que empieza a abandonar las prácticas asistencialistas y que asume una posición revolucionaria distinta. El fin de abordar el tema de las teologías indias es comprender una etapa importante en la transformación de la pastoral indígena, pero también porque a través de este fenómeno empieza a concretarse más el papel de las sociedades indígenas en tanto sociedad civil, en una dinámica que ofrece algunas pistas del contexto de gobernanza de incipiente gestación.

\section{Las teologías indias}

A lo largo de los siglos, lo que se concibe hoy como Latinoamérica se ha caracterizado por una estructura social marcada por la desigualdad. Uno de los sectores de la población más vulnerables ha sido el indígena. Ciertamente, no puede plantearse un panorama tan polarizado, pues los matices que se advierten en el escenario indígena explicitan que entre esos grupos existen también relaciones de poder y no sólo un esquema de "dominado-dominante" que corresponde al indígena y no indígena.

Si se consideran concepciones como la de Pablo González Casanova (2006) cuando se refiere al colonialismo interno, es una realidad que en América Latina la desigualdad y la exclusión 
se refleja en la diferencia entre el mundo urbano y el rural, y al indígena siempre se le asocia con lo rural, que en nuestro continente es quizás el sector más afectado, más desvalido y con mayor nivel de impunidad desde hace siglos. Ya se ha advertido en el capítulo precedente que la Iglesia católica, a mediados del siglo XX, buscaba modificar su papel colonialista que tanto la representó durante el periodo conocido como Conquista espiritual, en la primera mitad del siglo XVI y las etapas posteriores del colonialismo, hasta la publicación de la encíclica papal Rerum Novarum en 1891, cuando este organismo asumió una posición social. No hace falta adentrarse más al significado del Concilio Vaticano II, al que se ha dedicado un espacio en esta obra, para observar el rol social y comprometido de una Iglesia que buscaba romper con la tradición y acercarse más al pueblo. No obstante, lo que no se había logrado modificar a pesar de la reforma conciliar era la perspectiva monogenética que caracteriza a un etnocentrismo que tiende a no reconocer la diversidad étnica (Todorov, 1989).

Este etnocentrismo ${ }^{13}$ ha propiciado que el catolicismo continúe como una entidad con algunos tintes coloniales, por no reconocer las particularidades y diferencias de los pueblos en los que concentra su labor pastoral. No se establece, por lo tanto, el diálogo anhelado después de la reforma conciliar y asume una postura hacia los otros (indígenas) como menores de edad,

${ }^{13}$ Para Tzvetan Todorov (1989, p. 21), el etnocentrismo "consiste en el hecho de elevar, indebidamente a la categoría de universales los valores de la sociedad a la que yo pertenezco [...] Éste [el etnocentrista] cuando aspira a lo universal, parte de algo particular, que de inmediato se esfuerza por generalizar; y ese algo particular tiene que serle necesariamente familiar; es decir, en la práctica debe hallarse en su cultura". 
pensando que deben ser receptivos y que debe hablar por ellos, es decir, representarlos (Tomichá, 2013). ${ }^{14}$

Los cambios que ha tenido la acción pastoral católica en muchos de estos contextos con la llamada pastoral indígena se han concentrado más en la conversación y reconocimiento de la diversidad cultural, que rompe con acciones pastorales tradicionales y conservadoras, y se enfoca más en labores prácticas y menos dogmáticas como la agroecología, una educación integral y útil para el contexto de las comunidades o la revaloración de la cultura.

Alicia Barabas señala una dinámica de discriminación que aún es posible observar en la pastoral católica y de otras denominaciones cristianas, es decir, "la discriminación hacia el Otro que tiene una religión y una cultura diferentes, a las cuales, en un acto de hegemonía, se pretende erradicar o, como en este caso, transformar hasta el punto de descaracterizarlas en pro de la evangelización católica" (Barabas, 2015, p. 7).

$\mathrm{Al}$ respecto, es lógico que la visión etnocentrista propia de la Iglesia y sus integrantes resurja en ciertos momentos. Aún puede ser visible en algunos sectores religiosos católicos y no católicos que interactúan con grupos indígenas muchas formas de "discriminación religiosa", que en esencia consisten en no aceptar el

${ }^{14}$ En un contexto en el que la liberación era un objetivo claro en la acción pastoral y en entornos indígenas, surge la teología india que, desde la perspectiva de Tomichá, tiene el propósito de "ofrecer a las Iglesias cristianas y comunidades teológicas la experiencia y sabiduría milenarias de los pueblos autóctonos, invisibilizados o considerados 'menores de edad' por siglos, pero que a partir de las últimas décadas del siglo pasado comenzaron a adquirir una relevancia sociocultural, política, e incluso teológico-eclesial" (Tomichá, 2013, p. 1777). 
credo del otro. Al cabo, el ideal de comprender la otredad y fusionarse con ella es parte de una utopía y motivo suficiente para cuestionar la llamada inculturación. Pero debe reconocerse que ha habido una transformación sin precedentes en la acción pastoral en varios contextos indígenas.

Los cambios que ha sufrido la Iglesia y su acción pastoral son visibles en dos dimensiones: en lo local y lo global. Por un lado, localmente es evidente la forma en que muchos agentes de pastoral han pasado de una etapa doctrinaria a una revolucionaria y/o teopolítica, como los jesuitas en Bachajón, Chiapas, o en Santa María Chiquimula, Guatemala; los dominicos en Ocosingo, Chiapas, o en Alta y Baja Verapaz, Guatemala; los maristas en Comitán, Chiapas, o en Quiegolani e Ixtaltepec, Oaxaca, y muchos diocesanos que en estas zonas -por no mencionar la labor de otras congregaciones y agentes de pastoral en Centroamérica, Ecuador, Colombia, Brasil, entre otros- han logrado establecer una interacción más respetuosa y se han alejado de las prácticas doctrinarias y asistencialistas en pos de mejorar y comprender las necesidades de las comunidades.

Por otro lado, en el plano global se observa una serie de cambios, aunque ha sido con otro ritmo. En esta dimensión más macro, la época en la que se advirtió y empezó a ser cada vez más común el término teología india fue durante la gestión del obispo de Roma, el cardenal Karol Wojtyła (papa Juan Pablo II), quien a pesar de su posición contraria a la teología de la liberación tenía una preferencia por lo indígena. A partir de ese momento la Iglesia se actualizaba, pero con cierta cautela.

En realidad, cuando más abierta se mostró la Iglesia, sobre todo en cuanto a la parte de la teología india, fue con la llegada 
del cardenal Jorge Mario Bergoglio al papado (papa Francisco), pues es claro que su antecesor Joseph Ratzinger (papa Benedicto XVI) consideraba que la aceptación, inculturación y autoctonización de la religiosidad era un paso hacia atrás, como señaló en la última CELAM en Aparecida, Brasil, en 2007: "La utopía de volver a dar vida a las religiones precolombinas, separándolas de Cristo y de la Iglesia Universal, no sería un progreso, sino un retroceso. En realidad, sería una involución hacia un momento histórico anclado en el pasado" (V CELAM, 2007, pp. 10-11).

No debe extrañar este tipo de declaraciones que respaldan el argumento de Barabas y la discriminación religiosa, no por sólo por la ideología conservadora de la Iglesia y, en su momento, de Benedicto XVI o por representar un organismo que por tradición ha expresado un cierre étnico como parte de su estructura colonial, sino por los tintes que las teologías indias han heredado del liberacionismo latinoamericano, pero también de la aspiración de construir una Iglesia autóctona, lo que en muchos contextos es visto como una suerte de autonomía o de escisión del organismo eclesiástico.

Tal vez desde su llegada Bergoglio ha mostrado prudencia al respecto y se ha concentrado en pronunciar un discurso global en relación con los problemas que sufre el mundo, mucho más enfocado en la inclusión y en romper con la cultura o filosofia del descarte. Prueba de esto es cuando, poco tiempo después de haber asumido el cargo, durante la Jornada de la Juventud en Argentina, dijo:

¿Qué es lo que espero como consecuencia de la Jornada de la Juventud? Espero lío. Que acá dentro va a haber lío va a haber, 
que acá en Río va a haber lío va a haber, pero quiero lío en las diócesis, quiero que se salga afuera, quiero que la Iglesia salga a la calle, quiero que nos defendamos de todo lo que sea mundanidad, de lo que sea instalación, de lo que sea comodidad, de lo que sea clericalismo, de lo que sea estar encerrados en nosotros mismos, las parroquias, los colegios, las instituciones son para salir, si no salen se convierten en una ONG iy la Iglesia no puede ser una ONG! Que me perdonen los obispos y los curas, si alguno después les arma lío a ustedes, pero es el consejo. Gracias por lo que puedan hacer (AciPrensa, 2013, párr. 3).

En este encuentro y en otros más, el papa Francisco ha insistido en la necesidad de que la gente se exprese, de ser más pragmáticos, de que la Iglesia esté afuera en las calles, que se rompa con la exclusión de los ancianos, de los jóvenes, quienes "tienen que salir, tienen que hacerse valer, los jóvenes tienen que salir a luchar por los valores, a luchar por esos valores, y los viejos abran la boca, los ancianos abran la boca y enséñennos, transmítannos la sabiduría de los pueblos" (AciPrensa, 2013, párr. 7).

En esta denuncia del papa hacia la segregación de los pobres, los ancianos y los jóvenes, se perciben sus bases liberacionistas, jesuíticas y su influencia de la teología de la liberación durante su juventud en Argentina. Sin pronunciarse abierta o exclusivamente hacia los pueblos indígenas, se observa la posición de la Iglesia actual hacia la resolución de problemas muy relacionados con la cuestión ecológica, en un tipo de pastoral de la Tierra que destaca en su encíclica Laudato sí. En este sentido, la teología india no deriva por completo de la teología de la liberación, pero sí comprende los fundamentos liberacionistas. 
En cualquier caso, la dimensión global y la representación de la Iglesia con un ritmo diferente al de aquellos agentes de pastoral in situ e in praxis se ha ido transformando y se ha manifestado en América Latina en una plataforma ya existente, que es la llamada Iglesia de los pobres.

A la par de la idea del papa Francisco, quien declara que los pobres lo evangelizan, que son ejemplo de evangelio y que su deseo es una "Iglesia pobre y para los pobres" (L'Osservatore Romano, 2013, párr. 1), muchos herederos, incluso antiguos actores de la teología de la liberación y la opción por el pobre, llevan a la práctica una acción pastoral comprometida en contextos indígenas y de reconocimiento de su identidad. El caso del obispo emérito de Tehuantepec, Oaxaca, Arturo Lona Reyes, es representativo y muy firme su posición cuando declara que "los pobres son mi universidad, de ellos he aprendido lo poco que he transmitido a la gente" (El Observador, 2015, párr. 1), lo que alude a un involucramiento, es decir, ser parte de ellos y no sólo una acción de vivir y trabajar con los pobres.

Es lógico vincular a la Iglesia de los pobres con la teología de la liberación y la pastoral indígena, como se expresó en el capítulo precedente, con el caso de Chiapas. Sin embargo, la transformación y conformación de la Iglesia de los pobres en un contexto más actual consiste en una forma de vida que el propio monseñor Arturo Lona Reyes ha mostrado con acciones como la defensa de presos indígenas, campañas de recuperación de tierras de pueblos originarios, así como la afirmación de que no se irá del Istmo de Oaxaca porque "soy de los indígenas" (El Observador, 2015). He aquí el sentido de la pastoral indígena. La Iglesia de los pobres implica un reconocimiento de la diversidad cultural y étnica, 
incluyendo una mecánica de inculturación, que en el terreno religioso también demanda reconocer otras formas de vivir la religión, otros elementos espirituales y culturales.

En este punto es cuando se puede hablar de diferentes reflexiones de fe y cosmovisiones que convergen, sin que esto signifique que se mezclan. En la década de 1990 se hablaba de teología india, así, de forma general. En la actualidad se busca hacer una diferencia entre estas formas de fe y religiosidad, por lo que se alude a muchas teologías indias. Se trata de tantas teologías como diversas son las poblaciones de México y América Latina. De hecho, se asume que hablar de teología india en singular es negar la diversidad o someterla a una universalización (López, 2006), peculiar de una Iglesia católica por tradición monogenética, colonialista y etnocentrista.

Como se puede establecer hasta este momento, las teologías indias se forjan a partir del reconocimiento de diferentes formas de fe existentes desde antes de la llegada de los europeos a tierras americanas, pero también en donde confluye el cristianismo en una suerte de aculturación o fusión de elementos culturales e ideológicos recíprocos a lo largo de los siglos de contacto entre estas manifestaciones religiosas. Asimismo, debe considerarse la postura dominante del catolicismo, pero hoy -con un discurso de aceptación, ecumenismo, encarnación o inculturación del mensaje cristiano en las culturas indígenas- parece posible una teología india producto de una síntesis de la religiosidad autóctona y del cristianismo que per se, y según se maneja en el mensaje eclesiástico, no proviene ni ofrece una cultura en particular, pues la palabra de Dios no tiene cultura. 
Arias Montes y monseñor Bartolomé Carrasco señalaban que:

El Evangelio no es incompatible con las culturas humanas, tomando elementos de ellas y abriéndose a las diferencias, incluso de religiones. La misión no es una destrucción, sino purificación y nueva construcción. No subyuga, sino que devuelve a cada pueblo el orgullo de su identidad y la valentía de ser y mostrarse con su rostro propio, conduciéndolo a la plenitud, con la fuerza del Evangelio y de su cultura (Arias Montes \& Carrasco, 1998, p. 99).

En otras palabras, estos procesos de discernir la cultura del otro, de mirar desde el cristianismo las religiones de los otros, por utópico que sea, es parte de la transformación de la Iglesia desde lo global hasta lo local que se observa en los contextos indígenas latinoamericanos. La perspectiva del arzobispo de Oaxaca (19761993) Bartolomé Carrasco era que "los indígenas de manera especial, así como el pueblo sencillo, me han enseñado que los tres pilares de una auténtica teología son la palabra de Dios, el magisterio de la Iglesia y la realidad del pueblo que es auténtica voz de Dios que nos interpela y compromete" (Arias Montes \& Carrasco, 1998, p. 20), pero se enfatiza que esto no ha salido de los libros, sino del trabajo pastoral y de las necesidades reales; de hecho, señala Carrasco, los agentes de pastoral poco tiempo tienen de leer un libro de teología de la liberación, por lo que viven y comprenden el evangelio con el pueblo y en la práctica (Arias Montes \& Carrasco, 1998).

Es importante destacar estos aspectos, pues para pensar en una teología india debe considerarse que más que un contenido 
teórico, canónico e intelectual, se ejerce en la convivencia y en la praxis por parte de los agentes de pastoral que no sólo observan el comportamiento de los pueblos indígenas, sino que buscan comprometerse, entender al otro, incluso ser uno mismo con el otro.

En este orden de ideas, no es suficiente una pastoral que ponga los ojos en los pueblos indígenas, sino que tenga un rostro indígena a partir de "ser sensible a los problemas, respetar sus rasgos culturales y que el mensaje evangélico se inculturara en su cosmovisión y cultura" (Valtierra Zamudio, 2018b, p. 82).

Cuando se puso el ejemplo de la diócesis de San Cristóbal de Las Casas, se habló de una pastoral indígena cuyo propósito inicial fue el respeto a la diversidad cultural, un involucramiento del catolicismo en esta diversidad y la construcción de una Iglesia autóctona, es decir, una Iglesia que represente la inculturación del mensaje cristiano, revestida de todos los elementos y rasgos culturales indígenas.

Las teologías indias deben entenderse como diferentes formas de religiosidad indígenas, como bien puede observarse una teología india zapoteca que engloba todos los elementos propios de una cosmovisión y religiosidad autóctona zapoteca, así debe pensarse en el caso de los ayuuk, de los ixcatecos, de los totonacos, de los rarámuri, entre otros. Sin embargo, en estas formas distintas de religiosidad autóctona está entretejida toda una visión y praxis cristiana producto de la evangelización y conquista espiritual, en una suerte de sincretismo. Por esta razón, según el sacerdote zapoteco Eleazar López, hay una forma de diferenciar lo que se concibe como teologías indias para referirse a aquellas anteriores al cristianismo, las que existían previo a la llegada de los europeos al "Nuevo Mundo". 
Bartolomé Carrasco aclara que es necesario profundizar el diálogo con las religiones no cristianas que pertenecen, por el proceso de colonización, a aquellos que han sufrido rechazo y marginación. El reconocimiento de estas religiones implica aceptar que antes de haber "indios", había zapotecos, mixtecos, rarámuris, aymaras, mapuches, nahuas, kunas, navajos, guaraníes y muchos otros más, por eso "decirnos indios, nombre que nos fue impuesto por los invasores europeos, no es llamarnos por nuestro nombre, sino indicar nuestra condición de oprimidos" (Arias Montes \& Carrasco, 1998, p. 221).

En las relaciones (neo)coloniales que persisten hasta el día de hoy, es claro que continúa la explotación o exclusión de los indígenas. En su contexto, empero, son portadores de un conocimiento, una memoria que han heredado del pasado y se refleja en su cosmovisión y su religiosidad. Las teologías indias están definidas en esta religiosidad y cosmovisión, lo que es un hecho es que desde la perspectiva de la Iglesia católica el cristianismo no es excluyente y opuesto a estas formas de religiosidad autóctonas. Parece contradictorio esto si se analiza el discurso inaugural del papa Benedicto XVI en la CELAM de Aparecida; pero más allá de la posición oficial de Roma, en el mensaje de jerarcas como Bartolomé Carrasco, Samuel Ruiz, Arturo Lona Reyes, Raúl Vera, entre otros, la base liberacionista de la pastoral y el reconocimiento e inculturación del evangelio en estas teologías indias no son opuestas al cristianismo, sino un complemento.

Para Carrasco, la teología india entraña una metodología que comienza por el reconocimiento de la actualidad, lo que implica escudriñar el pensamiento religioso de los antepasados indígenas y su espiritualidad, reconocer al sujeto, a la comunidad 
y su sabiduría, su lenguaje mítico y simbólico, así como fortalecer la vida de la comunidad en sus múltiples expresiones para transformarse a favor de los pobres (Arias Montes \& Carrasco, 1998, p. 227). Así, cristianismo y cosmovisión indígena conforman una Iglesia autóctona, ${ }^{15}$ que es el fin último de la teología india, pero también está relacionada con el compromiso de liberación.

En este punto de la discusión se habla de teología(s) india(s) en alusión a la religiosidad autóctona, pero también al cristianismo que discierne y se encarna en estas teologías. Sin embargo, mucho de este proceso conduce a pensar que no se está hablando de los mismos conceptos. Es por eso que el sacerdote de origen zapoteco Eleazar López (2006) hace una distinción de teologías indias: la teología india-india y la teología india cristiana. La primera refiere a la religiosidad autóctona que no tiene relación con el cristianismo, sin embargo, sí tiene contacto con él, pero en lo que Eloy Mosqueda identifica como "un mensaje que necesariamente estaría en consonancia con el cristianismo, es decir, con la interpretación que la diócesis tenía de éste" (Mosqueda, 2011, p. 70). Para el cristianismo, es en las teologías indias o en la teología india india que se rescata - o reinterpreta- un mensaje salvífico contenido en las propias culturas autóctonas para relacionarlo/adaptarlo a aquél, lo que lleva a esta teología india-india

\footnotetext{
${ }^{15}$ En un documento que generó una misionera de la Misión de Guadalupe de Comitán, explica que la Iglesia autóctona es "Una iglesia que nace de las Semillas del Verbo sembradas en nuestra cultura y religión propias. Es una Iglesia con rostro, corazón y pensamiento propio del pueblo donde nace. La Iglesia Autóctona es fruto de la Inculturación del Evangelio. Iglesia que lleva el nombre y el ser de cada pueblo con su propio clero, su propia organización, su propia espiritualidad, su propia liturgia y su propia teología" (Refugio, 2008, p. 1).
} 
a conformar una teología india cristiana, que es la segunda clasificación que propone López. En esta segunda teología se enfocará el siguiente apartado.

\section{Teología india india y teología india cristiana}

La teología india por sí sola es definida por los propios pueblos indígenas como fusión entre el cristianismo y la religiosidad autóctona. Así, puede pensarse en una síntesis religiosa sin conflicto, aunque estas perspectivas no sólo cambian de población en población, incluso dentro de una misma comunidad. Para el guía espiritual quiché Eduardo León, la teología india es una forma de navegar a la vez en dos ríos o una manera de convivir o interactuar entre dos culturas y cosmovisiones distintas.

Yo siento que culturalmente a nosotros no se nos dificulta lo extraño y lo moderno. Por ejemplo, es una opción personal para nosotros. A mí, personalmente, no se me impuso lo del cristianismo como lo narra Falla en su «Quiché Rebelde». ¡No! [golpeando la mesa con el puño] En el caso mío no fue que a mí me evangelizaron y, pues, me convencieron «que hazte cristiano». ¡No!, sino fue una opción personal porque lo que me motivó a mí es la historia detrás de cómo la evangelización llega a Santa María [Chiquimula]. Llega arrasando con toda la cultura y ¿qué aportación yo daría como indígena adentro? Ese es el gran reto en donde yo me encontré, pues; o sea, yo culturalmente estoy cimentado desde mis raíces. Mi abuelo fue así también. Él iba a la Iglesia, no iba a misa, pero iba a procesiones; tenía una gran fe. Cuando llegan a rezar en su casa, él mostró el otro lado como de decir: «ustedes como evangelizadores 
están peliados (sic) con nosotros, pero nosotros no». Entonces, el acercamiento que yo hice fue con esa actitud: ¿cómo desde la Iglesia ayudo a mis hermanos indígenas que no olviden sus raíces? Y que lo cristiano no es más que mi cultura y que mi cultura más que lo cristiano, sino debe ser resultado de cómo conjugar esas dos dimensiones, cómo navegar en esos dos ríos, cómo consolidar esos dos amores. Eso es una realidad humana (en Valtierra Zamudio, 2018a, pp. 259-260). ${ }^{16}$

$\mathrm{Al}$ considerar que la religiosidad que se manifiesta en cualquier sociedad conlleva una cosmovisión y una cultura, la teología india -según la concibe este guía espiritual quiché- comprende una naturaleza dialógica e interreligiosa. El peligro de la teología india desde la Iglesia es que el diálogo propiciado y el escenario interreligioso e intercultural es desigual, es decir, predomina una interpretación de la palabra o perspectiva antigua de los pueblos indígenas en el discurso religioso que opaca la propia voz de los indígenas. La crítica del guía espiritual quiché al respecto es que mientras los pueblos indígenas debieron asimilar y comprender sin conflicto la religiosidad cristiana y sin abandonar en muchos casos la religiosidad autóctona, no ha sido siempre así en el caso de los agentes de pastoral que han hecho una especie de selección de los elementos autóctonos para integrarlos a la teología india.

${ }^{16}$ Esta cita que puede encontrarse en otros textos de mi autoría fue parte de una entrevista abierta a Eduardo León Chic, en diciembre de 2008, después de un viaje a su comunidad en Santa María Chiquimula, Guatemala, donde también hubo un acercamiento con el misionero jesuita Ricardo Falla, cuya perspectiva es un poco distinta a la de Eduardo en el tema de la teología india. 
En este tono, Mosqueda afirma que la asimilación de las religiones autóctonas por parte de la Iglesia católica, a través de la teología india, "no es otra cosa que una asimilación más sutil de las culturas a través de su reconocimiento, siempre y cuando se realice en términos de lo que interpretan como cristiano" (Mosqueda, 2011, p. 70). En otras palabras, una mecánica inicial de la teología india ha sido que los indígenas reciban el cristianismo, pero no al revés, pues el cristianismo católico puede estar "revestido de autoctonía", pero no acepta desde la cúpula, incluso desde las bases, elementos como el politeísmo u otras prácticas que se contraponen al dogma, lo que genera un tipo de "cierre étnico". Entonces, ¿qué es lo que se entiende por teología india? En específico, ¿en qué consiste la teología india cristiana?

Para empezar, debe pensarse en el catolicismo no como uno solo. Elio Masferrer habla de muchos catolicismos como parte del pluralismo religioso en el contexto latinoamericano, en donde también hay un pluralismo católico que se desarrolla a partir del Concilio Vaticano II y los procesos de contacto intercultural, que inspiran más adelante el impulso de configurar un rito religioso indígena dentro de la catolicidad, en contraposición al ala conservadora de la Iglesia católica (Masferrer, 1998, p. 8). Para este antropólogo de la religión, el pluralismo católico en contextos indígenas se divide en varios catolicismos; el de carácter indígena es practicado por quienes desde su cosmovisión ha desarrollado y han leído la doctrina y contenido católico.

De igual forma, hay católicos tradicionalistas indígenas entre quienes el peso de las religiones étnicas domina sobre el catolicismo y, finalmente, hay un catolicismo de los actores no indígenas que se denomina catolicismo mestizo, caracterizado 
por una ideología de "dominación y supremacía racial durante el periodo colonial e independentista" (Masferrer, 1998, p. 8), que perfectamente se puede proyectar hasta el día de hoy. Además de esta clasificación, destacan los católicos de la teología india que, como también sostiene Mosqueda, representan una síntesis de los catolicismos étnicos, pero vinculados a las bases de la teología de la liberación latinoamericana.

Desde la mirada de Samuel Ruiz, la teología india es una reflexión de los indígenas sobre su fe ancestral, pero también de su fe cristiana; es decir, miran el cristianismo desde su cultura, lo que hace de esto una suerte de catolicismo que Carlos Garma califica como "resultado de la confluencia de creencias, prácticas y símbolos tanto de origen amerindio como ibérico" (Garma, 1998, p. 194). No obstante, establece este autor:

La Iglesia católica tolera la religiosidad popular como una forma de acercarse a la divinidad, pero considera que debe ser encauzada hacia expresiones más acordes con la doctrina oficial de la Iglesia. De aquí se deriva el papel de las diversas líneas de acción pastoral dirigidas específicamente a los pueblos indígenas, las cuales han sufrido diversas variaciones a través de los siglos desde la primera evangelización (Garma, 1998, p. 194).

El panorama se torna más complejo ahora, pues en el discurso del guía espiritual quiché del inicio de este apartado y en el de monseñor Samuel Ruiz se habla de una fusión, de asimilación de dos perspectivas, pero se contrapone a los argumentos de algunos especialistas como Garma o Masferrer, quienes refieren a una síntesis, lo que implica una selección de elementos y/o rasgos 
culturales y cultuales de las teologías autóctonas para insertarse o que converjan con el cristianismo católico. Este es uno de los principales argumentos para clasificar a la teología india en diferentes tipos y en el caso de la síntesis de los elementos culturales autóctonos dentro del cristianismo, debe hablarse de teología india cristiana.

Esta teología, sin embargo, no es tan reciente. Incluso en otros contextos latinoamericanos se hablaba de ella antes de 1990, cuando se observa, por lo menos en México, un mayor impulso. Sus bases ideológicas se hallan en el periodo de conciencia étnica por parte de la Iglesia católica, que se ubica en la década de 1970. El teólogo Manuel Marzal ya la mencionaba en una publicación de 1973, en la que señala una diferencia entre una Iglesia autóctona, que consiste en la fidelidad desde el cristianismo a las propias raíces culturales, y una Iglesia autónoma, que se refiere a aquella que vive de los recursos que esta misma genera y que se gobierna a sí misma (Marzal, 1973).

El propio Marzal advierte que la Iglesia autóctona camina por la vía de la teología india para establecer una Iglesia local y así paliar la escasez sacerdotal, promover el sacerdocio entre los indígenas y frenar la noción del indígena como dependiente y menor de edad. La base conciliar al respecto consiste en no imponer la rigidez doctrinaria, litúrgica y la uniformidad en aquello que no afecta la fe o el bienestar de la comunidad (Marzal, 1973).

En el caso de México, como ya se había dicho, el evento en donde sobresalió el concepto de teología india fue la CELAM de Puebla, en 1979, en donde al estar en "tela de juicio" la llamada teología de la liberación, el concepto de pobre se amplió a partir de las peculiaridades de la población mexicana y se reconocieron 
sus características y particularidades culturales, por lo que empezaron a surgir algunos términos y reflexiones de fe como la teología negra, teología feminista, teología india, entre otras (Gil Tébar, 1997; Shorter, 1988).

La discusión respecto de los indígenas se centró en la necesidad de una transformación y replanteamiento de la pastoral indígena, aunque con la base de la opción por el pobre y liberación del oprimido. Sin embargo, a diferencia de muchos contenidos teológicos, la teología india "no brota de una construcción teórica, sino una realidad presente y latente dado al oficio que la ha relegado por la imposición de la teología occidental" (Gil Tébar, 1997, p. 398). Desde esta perspectiva, la teología india tiene una base que bien podría localizarse en el periodo colonial, esto es, desde el momento en que la actividad de la Iglesia en la ciudad se dirigía a blancos y mestizos, y en el mundo rural hacia los pobres, sector que conformaban la mayoría de los indígenas y campesinos (por lo general de origen indígena). De esta forma, en el ámbito rural se mezclaba con los antiguos cultos y religiones autóctonas (Dussel, 1995).

Aquí es importante hacer una aclaración, pues con esta última idea dusseleana se tiene una visión de larga duración de un cristianismo que se va fusionando y entretejiendo con las religiones autóctonas. Empero, cuando se habla de teología india cristiana en términos de una transformación de la pastoral indígena con bases liberacionistas, quizás debe considerarse una perspectiva de corta duración en la que lo que prevalece es una reinterpretación de esos elementos culturales, por lo que podría pensarse en una metodología pastoral del siglo XX que se sustentaría en una acomodación de la Iglesia 
católica a lo autóctono, a partir de la reinterpretación y reinvención de un contexto sociorreligioso y sociocultural.

La construcción de la teología india cristiana desde esta óptica se ha basado en una religión concebida como única y verdadera, y aunque se argumenta que el mensaje cristiano no está sujeto a una cultura en particular, sino que se encarna en las culturas, es claro que a esta base se van incorporando elementos asumidos como nativos y se reviste de la riqueza de muchas religiones autóctonas. Ante esta situación, una misionera chiapaneca tsotsil manifiesta su desconcierto, pues:

[...] el problema es que todavía no está en nuestras manos [la teología india]. Hace falta más compromiso. En la coordinación, si acaso está un indígena es porque es principal. ${ }^{17}$ Entiendo que es un espacio espiritual muy nuestro y que no todos van a vivir o entender lo de nosotros, entonces ¿por qué los que coordinan estos espacios son en su mayoría caxlanes ${ }^{318}$ (Alcázar, conversación personal, 2010).

La coordinación de los grupos de teología india cristiana y sus componentes, como los ritos y altares, se aproxima a definirla como un espacio o plataforma creada por la misma Iglesia católica a partir de la manifestación selectiva de elementos religiosos identificados por el catolicismo como autóctonos, de los que se

${ }_{17}$ Principal se refiere a los indígenas que tienen algún cargo importante o que son líderes.

${ }^{18}$ Caxlán significa mestizo. 
retoma un mensaje de salvación de las culturas indígenas que el catolicismo interpreta como una idea de Iglesia autóctona.

El método de la teología india cristiana es seguir un conjunto de prácticas con una presentación menos ortodoxa, menos doctrinaria y más afín a los contextos en los que los misioneros e indígenas interactúan. En dichos contextos se intenta hacer una síntesis de los rasgos culturales y la cosmovisión de la diversidad de pueblos que convergen en encuentros de teología india, lo que en el fondo implica concentrar esa síntesis en algo más uniforme y asequible, en donde predomina la mano de la Iglesia católica.

$\mathrm{Al}$ cabo, la teología india cristiana es "un escenario o mosaico formado por muchas cosmovisiones y manifestaciones religiosas, acordes a la cultura que las expresa" (Valtierra Zamudio, 2018b, p. 86), pero también debe entenderse como una teología de los pueblos oprimidos; es decir, la teología india cristiana no puede comprenderse sin los principios de liberación y la noción no sólo de una Iglesia autóctona, sino de una Iglesia de los pobres, desde la que se diseña "una teología empeñada en romper con la homogeneidad que empobrece la realidad al ignorar la variedad de matices" (Gil Tébar, 1997, p. 398).

El método que se identifica para la teología india cristiana y que Pilar Gil Tébar resalta, más allá de su carácter pragmático y menos teórico, es su concentración en pueblos donde el cristianismo se ha implementado de forma superficial y que poco ha modificado las formas religiosas anteriores. Una vez ahí, sin que se renuncie a las creencias católicas, se reafirma la identidad indígena en una especie de síntesis entre catolicismo y autoctonía, que no sólo incluye uno o más credos, sino cuestiones que afectan 
la vida cotidiana, como tradiciones sociales, culturales, religiosas o las relaciones humanas mismas (Gil Tébar, 1997).

Con esta metodología y esta perspectiva de la teología india cristiana se complementa la noción de este concepto, como señala Eleazar López, para quien es "un conjunto de experiencias y conocimientos religiosos de los pueblos indios que explica su experiencia de fe dentro de su visión del mundo" (López, 2006, p. 75). La definición de López es interesante, pues ahora no se trata sólo de características y rasgos culturales, creencias, entre otros elementos, sino de una memoria histórica que tiene un papel fundamental en la identidad. Las teologías indias la perciben como un "acervo de prácticas religiosas" (López, 2006, p. 75) y, por ende, como un conjunto de memoria de las prácticas, cosmovisión, creencias, interacción, entre otros aspectos y fenómenos socioculturales y sociorreligiosos; por lo tanto, significa el reconocimiento de una religiosidad popular por parte de la Iglesia católica hacia las creencias autóctonas, sin estar desvinculadas del cristianismo.

Sin embargo, López también afirma que es un medio para reiniciar el diálogo interreligioso, que es uno de los aspectos que se traducen del mensaje del Concilio Vaticano II:

Con Teologías indias no se pretendía iniciar una corriente teológica nueva en la Iglesia ni encubrir una teología cuestionada por el Magisterio. Lo que se llama Teología India Cristiana reconoce que ya se está dando una inculturación o apropiación indígena del Evangelio y de la Iglesia a través de la Religiosidad Popular en menor medida compartida por no indígenas (López, 2006, p. 79). 
Lo que ha cambiado mucho entre el cristianismo tradicional y lo que se ha captado de la religiosidad autóctona es que en el primero hay una base teológica que consiste en una comunicación con Dios a través de racionalizar el contenido dogmático, el discurso y la oración, mientras que en el caso de las religiones originarias el fundamento es más vivencial, vinculado con el entorno ecológico y separado de una institución. Así, es lógico pensar que la Iglesia con su estructura canónica no sea compatible con la religiosidad indígena; pero en esencia -y eso sucede en cualquier religiónmás allá de la doctrina, las religiones se caracterizan por la parte vivencial y la espiritualidad. Es ahí donde la teología india cristiana, en apariencia, converge con la religiosidad autóctona y de esa base compartida que es la experiencia se genera la síntesis de elementos que se insertan en un culto y ritual "fusionado". Al final, el objetivo en común es una noción de Dios, por lo que la adaptación de cristianos a la religiosidad indígena y viceversa llega a ser relativamente simple (Marroquín, 1999; Ruiz, 1999).

Para comprender mejor este fenómeno religioso, a continuación se abordará el tema de la teología india cristiana desde una mirada y experiencia etnográficas.

\section{La teología india cristiana a partir de un análisis etnográfico}

En diferentes estancias de investigación en contextos indígenas del sur de México y Guatemala, la etnografía ha sido una herramienta eficaz para observar, registrar y comprender las dinámicas de rituales e intercambio de manifestaciones religiosas. 
Por etnografía debe entenderse una vía para tratar de comprender al otro, a quien se le concibe como aquel diferente dentro de una diversidad cultural con costumbres, prácticas, cosmovisiones y cosmovivencias que expresan lo distinto, a las cuales se busca entender (Ameigeiras, 2012). Ciertamente, se requeriría demasiado tiempo para tratar de asimilar elementos simbólicos y sus significados dentro de la cosmovisión de un pueblo indígena. No basta el recurso de la entrevista o de la observación misma para discernir las prácticas, significados y valoración de rituales o elementos simbólicos que, en ocasiones, llegan a ser tan sutiles que el ojo occidentalizado del científico social frecuentemente no los detecta; es por eso que la necesidad de una participación con y en la comunidad es vital, es decir, una observación participante.

Para Rosana Guber, la etnografía conlleva un enfoque que promueve la descripción de hechos sociales, pero en la que está implícita la interpretación del investigador. Sin embargo, también sigue un método en que el investigador participa, entrevista y permanece prolongadamente en el lugar (Guber, 2011), de tal forma que se incentiva la intervención dentro de la comunidad. Polin y Robertazzi (2015, pp. 234-235) advierten que "dicha tarea etnográfica se produce a lo largo del trabajo de campo, cuando el/la investigador/a va tomando contacto con el lugar, sus integrantes, cuando identifica referentes o interlocutores, escuchando, dialogando, sintiendo y escribiendo".

El ideal del antropólogo social, y podría pensarse también en el agente de pastoral, ha llegado a ser la nativización. Consiste en una situación utópica, pero sí ha sido necesario generar diversas estrategias para lograr comprender símbolos que están arraigados en 
cosmovisiones muy distintas a nosotros. En cierta forma, la ventaja de la teología india cristiana es que se contemplan elementos que son propios de una cultura "no indígena" y "occidental", por tratarse de la Iglesia católica, pero hay aspectos que pertenecen a otras culturas y que no tienen una explicación superficial o que puedan definirse con un concepto como tal.

Para esto hay muchos recursos con los que se puede intentar registrar componentes esenciales y en apariencia invisibles desde nuestros referentes culturales en escenarios como los encuentros o cursos de catequistas, en los que está presente la teología india cristiana y en los que la participación y la observación son torales. El ejemplo más adecuado es el del antropólogo Charles Briggs (2003), quien usó la entrevista con la comunidad denominada "mexicano", nombre que se le da a un grupo étnico en el norte de Nuevo México, EUA, para conocer y entender la técnica de la talla de madera en esa localidad, pero hubo muchos problemas en el proceso, pues la gente no respondía a sus preguntas o la información no era muy clara, incluso restrictiva. Hasta que analizó las respuestas que obtenía, así como las preguntas que él planteaba, empezó a idear otras estrategias.

Briggs descubrió, entonces, que si quería aprender sobre la talla y la tradición, tendría que adoptar el papel de principiante tradicional. Para enseñarle, sus anfitriones preferían seguir el método de darle una pieza de madera y un buril y ayudarle a tallar. Sólo una vez dentro de ese contexto, Briggs pudo conseguir más información sobre las tallas y su trascendencia sociocultural (Duranti, 2000, p. 132). 
Esta descripción de la obra y experiencia de Briggs que Alessandro Duranti hace, deja muy claro que en el proceso de investigación antropológica la entrevista no es suficiente para comprender actividades tan complejas como las técnicas de la talla de madera, incluso el significado de esta práctica para la cultura de la comunidad "mexicano" en Nuevo México. No es suficiente conocer la lengua de la comunidad a la que se va a realizar las entrevistas, sino se requiere de un registro etnográfico y una participación de la actividad en y entre la comunidad.

Esta observación participante demanda mucho tiempo y recursos económicos que son difíciles de obtener. Es lo que se necesitaría para entender más o menos una parte de la esencia de la religiosidad de una población indígena. Por esta razón, cuando se trata de la teología india cristiana, podría pensarse, es más sencillo comprender algunos códigos, pues es una cultura más cercana al investigador (la de la Iglesia y sus miembros, el cristianismo mismo, así como la perspectiva occidental). Empero, es importante considerar que aún en estos casos es determinante considerar que el contexto en el que está un agente de pastoral puede ser muy distinto al del antropólogo y que la interculturalidad se vive desde otra arista.

Los llamados conocimientos e investigación situados pueden ser muy útiles en el proceso de registro y discernimiento del contexto y hecho en cuestión. Se construyen a través de la experiencia del cuerpo; el investigador se subjetiviza, es decir, se vuelve sujeto de estudio y se posiciona en un entorno determinado, reconociendo su mismidad y su otredad en una suerte de proceso autoetnográfico. 
Así pues, la etnografía y la acción de "situarse" es importante cuando se indagan fenómenos religiosos, culturales, sociales, entre otros, sobre todo cuando esos contextos son inter y/o pluriculturales. Pero también asumir una posición determinada como investigador permite que al involucrarse en un medio complejo y pluricultural como el de un encuentro de teología india se identifiquen rasgos, actitudes y discursos que se adaptan al contexto con un propósito, diferenciándose del ámbito privado.

A continuación se expondrá una serie de ejemplos con base en un encuentro de catequistas en una comunidad de origen tojolabal y kanjobal, en donde la teología india cristiana y la reinterpretación de elementos culturales tojolabales y de otros grupos étnicos se observan con claridad en el ritual, en el que el investigador mismo ha participado para registro y comprensión del ritual.

\section{El jbankilal y la teología india cristiana: reinterpretación religiosa en Rizo de Oro, Chiapas}

Cuando se abordó el tema de la pastoral indígena y de la teología india cristiana, también surgió el concepto de Iglesia autóctona, que alude a una suerte de Iglesia con rostro, corazón y pensamiento indígena. $\mathrm{Al}$ ser ésta el fin último de la pastoral indígena y del proceso de inculturación, es importante explicar los efectos de reinterpretación religiosa que se registran en estas dinámicas y contextos, que no deben confundirse con el sincretismo religioso, término que causa controversia e incomodidad a la Iglesia católica, pero está presente en las religiones populares. Este último consiste en una mixtura de elementos religiosos o mundos diferentes que 
se entretejen, en un proceso de recombinación selectiva y creativa, es decir, "la formación, a partir de dos sistemas religiosos, de otro nuevo, cuyas creencias, ritos, formas de organización y normas éticas son producto de una interacción dialéctica en los dos sistemas en contacto" (Marzal, 2002, p. 197). Esto posibilita que persistan ciertos componentes originales de esas religiones con su misma forma y significado, y al mismo tiempo, la pérdida total y la síntesis de algunos con sus similares de la otra religión, así como la reinterpretación de otros (Marzal, 1991).

La reinterpretación religiosa no es contraria al sincretismo, sino una parte de él, esto es, una última fase por la que el sincretismo pasa. Es, en el caso del rito religioso, cuando se cambia su significado original y también cuando se le añaden nuevos significados. En otras palabras, el sincretismo religioso requiere de mucho tiempo, quizá siglos, para que ocurra; mientras sólo una parte del sincretismo es lo que se denomina reinterpretación religiosa y no requiere de tanto tiempo para que suceda. Dicha reinterpretación conlleva tres fases principales:

\section{Se acepta el rito cristiano y se le da un significado} indígena. Primera etapa que en una perspectiva de larga duración se identifica con la llegada de los europeos al nuevo mundo, quienes traen el cristianismo; los indígenas lo aceptan, lo reinterpretan y lo adaptan a su cultura desde su cosmovisión. En la actualidad es muy claro cuando se hacen celebraciones como "todos santos" - el kin santo, para algunos pueblos mayas-, pues no se trata sólo de la fiesta cristiana, sino de una representación relacionada con el ciclo agrícola que va de mayo a noviembre o el sat ixim (ojo maíz), durante 
el cual se colocan cruces de madera de color verde en los sembradíos o en la milpa, pero que se trata de:

[una] mata de maíz, pero eso ya es profundizar en toda la visión que ellos tienen, que todo gira alrededor del maíz, entonces vas a descubrir que esa cruz es maya $[\ldots]$ por eso vas a ver las cruces cómo no son de otro color, sino que son verdes, que es el color de la vida, pues es de la montaña [...] (Castillo Aguilar, entrevista, 2008).

Se advierte esta forma práctica de religiosidad vinculada con la naturaleza y el entorno, así como concentrada en un concepto similar a Dios que puede ser la Madre Tierra o el creador.

\section{Se conserva un rito indígena y se le otorga un mensaje} cristiano. Esto significa que el indígena conserva sus raíces y toma elementos del cristianismo para integrarlos o adaptarlos a su credo.

\section{Se acepta el rito cristiano, pero a su significado se} le añaden otros nuevos. Esta fase es central, pues se trata de una reinterpretación más relacionada con la teología india cristiana. Aquí es claro que por parte de los agentes de pastoral llega a haber una suerte de adaptación o acomodación de sus prácticas, cosmovisión y cultura en el contexto indígena y se esperaría lo mismo por parte de los indígenas. Uno de los agentes de pastoral en entrevista explica este proceso como algo que debe hacerse, pero no de forma tan inmediata: 
[...] no se puede hacer cosas propias de la cultura nuestra ahí [en las comunidades], porque eso sería como meter nuestras costumbres y nuestros criterios así nada más. No, uno debe escuchar y entender al hermano tojolabal, así se tenga que aprender su lengua y luego actuar conforme a lo que ellos acostumbran hacer [...] $\mathrm{Al}$ principio es complicado porque se enfrenta uno a cosas que no conoce. Luego uno tiene que... si el hermano baila, pues uno baila, si el hermano come en silencio, pus (sic) uno hace lo mismo, si el hermano llora, igual y hasta tienes que llorar (Gerardo T., entrevista, 2008).

En esta dinámica de adaptación es importante considerar un aspecto esencial de la reinterpretación religiosa, pues en la acción de "acomodarse" se estructura un escenario propicio para reinterpretar los ritos autóctonos y recrearlos. En la comunidad de Rizo de Oro, Chiapas, en un curso de catequistas que duró tres días, la participación de una agente de pastoral de nombre Bernarda ${ }^{19}$ da cuenta de esta reinterpretación.

Para comprender tal escenario es importante considerar dos aspectos esenciales: el altar maya y, sobre todo, el jbankilal. En el primer caso se trata de un altar conformado por flores de distintos colores que representan los cuatro puntos cardinales, las cuales aparecen en la mayoría de las culturas mesoamericanas: negro, amarillo, blanco y rojo. El altar es circular y en el centro se representa con color verde y/o azul la unión del cielo y la Tierra,

${ }^{19}$ Esta misionera pertenece, aún hoy, a la Misión de Guadalupe de los Hermanos Maristas en Comitán. Es parte del equipo de pastoral y es laica. El nombre de "Bernarda" se le asignó con el fin de proteger su identidad. 
razón por la que se usan esos colores, y con frecuencia se coloca un crucifijo que no es señal de sincretismo, antes bien de acomodación o adaptación.

\section{Imagen 1. Altar Maya ${ }^{20}$}

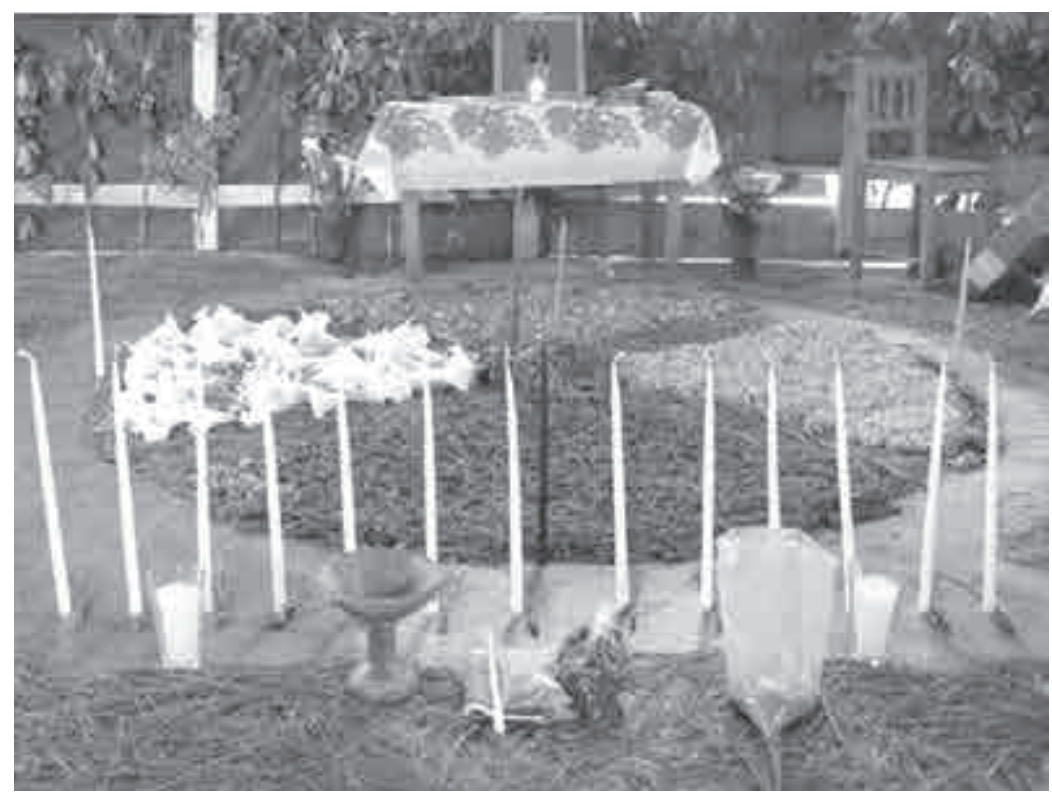

El altar maya, afirma el arqueólogo Horacio Olivares - con quien se sostuvo pláticas sobre el tema en varias ocasiones-, es un elemento que sí se halla en muchas culturas mayenses de Guatemala, pero sus dimensiones han sido determinadas por una política de Estado, a fin de que los pueblos mayas siguieran haciendo su altar, pero no en los monumentos y sitios arqueológicos, y

${ }^{20}$ Imagen de la cruz maya en la población de Nuevo Guadalupe, Chiapas, por Jorge Valtierra Zamudio. 
así evitar que resultaran dañados. Frente a tal situación es claro que existe una recreación de estos símbolos, en donde se involucran otros intereses y usos, incluso estatales. Sin embargo, lo que debe destacarse es la iniciativa de la Iglesia católica, a través de algunas misiones que han pedido orientación a guías espirituales mayas de Guatemala para explicar e incorporar el altar en varias comunidades.

El fin de lo anterior puede verse desde una perspectiva doble: por un lado, los intereses institucionales de mantener o fortalecer la presencia de la Iglesia católica en las comunidades; por el otro, la interpretación y convicción de inculturación de seguir un camino hacia la Iglesia autóctona, lo que conduce a una interpretación distinta de la que las propias comunidades le dan.

Esta interpretación que se busca poner en la práctica es parte del proceso selectivo y mezclado (no sincrético) que ha caracterizado a la teología india cristiana, o que por lo menos así se ha visto en muchos encuentros de este tipo. No obstante, este elemento que es muy visible en la teología india cristiana, sin hacer menos su simbolismo, tiene también un uso ornamental como los altares en general en distintas religiones. Aunque también hay otros componentes que no son quizá tan visibles, pero tienen un significado muy profundo, que no se entiende bien del todo desde la óptica no indígena o no maya y, aun así, se busca una interpretación desde el eurocentrismo y el cristianismo. Este es el caso del jbankilal, con el que se pretende, a través de una experiencia etnográfica, explicar e ilustrar grosso modo la teología india cristiana en la praxis.

El jbankilal consiste en tabaco pulverizado que en algunas partes se acostumbra comer en momentos específicos, sobre todo 
entre los tsotsiles y tseltales. Es difícil especificar el origen de esta costumbre, pero hay una adaptación interesante que tiene un sentido espiritual profundo y los agentes de pastoral lo equiparan con el "cuerpo de Cristo", empezando por el nombre de jbankilal, que significa en varias lenguas mayas, incluyendo el tojolab'al, "mi hermano mayor".

La práctica del jbankilal por Bernarda era constante y ella aclara que: "lo tomo cuando me siento así como apachurrada, cansada y con mucha tristeza en mi corazón" (Notas de campo, 23 de octubre de 2008). En Rizo de Oro, Chiapas, el papel de Bernarda como agente de pastoral laica era dirigir la sesión o curso de catequistas del 22 al 25 de octubre de 2008, en donde se "haría altar maya", se abordaría el tema del rescate cultural y se buscaría presentar varios de los componentes culturales que - desde la interpretación de la Misión a la que ella estaba adscrita- pertenecían a los tojolabale ${ }^{21}$ y se habían olvidado con el tiempo debido al proceso de colonización y la modernidad.

Bernarda inició la sesión dando la bienvenida. Sobre el piso ya estaban dispuestas 13 "candelas" o velas de color blanco, cuyo número es representativo en la espiritualidad maya. Entonces expresó:

[...] estoy muy contenta de la presencia de los hermanos que vienen de todas las comunidades. De Tepeyac, de Veracruz, San Carlos... Es momento de estar cabales, equilibrados, por eso se

${ }^{21}$ Los tojolabales son un grupo étnico de filiación lingüística mayense que habita en los municipios de Las Margaritas, La Trinitaria, Maravilla Tenejepa, Independencia y Altamirano, Chiapas, en la zona sureste del país. 
pide que se tomen unas candelas que son símbolo del amor que Dios nos dio y empecemos a danzar, a orar [...] (Notas de campo, 23 de octubre de 2008).

Mientras la misionera pronunciaba estas palabras, contaba con un huaje o bule que contenía el jbankilal que, como se mencionó, se usa para ceremonias y momentos de celebración de un ritual y lo que simboliza para los agentes de pastoral es equivalente a la hostia católica. Cada vez que Bernarda terminaba un tema o estaba en oración con los catequistas indígenas alrededor del altar maya, sacaba su huaje, se echaba polvo en la mano y lo ingería.

Hasta este momento hay dos fragmentos en el discurso de Bernarda que llaman la atención: el "símbolo del amor que Dios nos dio en las candelas", que alude a una interpretación personal, pues no se estipula en textos sagrados como la Biblia, sino en un calendario de signos mayas que ella consiguió en Guatemala, al reverso del cual en el signo de ese día (que era ajpu del calendario cholq’ï o tzolkin de adscripción quiché) se indicaban los elementos y significado que el número 13 y las velas tenían.

La actitud de los tojolabales presentes dejaba claro que no estaban muy familiarizados con estos aspectos ni con el altar maya. No es algo suyo, pero se justifica porque parte del tema de estos cursos de catequistas es el rescate de su cultura. Cuando se le preguntó a ella sobre estos elementos con los que no se sentían identificados los tojolabales, sin decir la fuente y mucho menos si fue testigo de esto, respondió: "los abuelos sí lo llevaban a cabo, en la época en que no era algo muy aceptado por la Iglesia, pero eso se fue perdiendo con el tiempo" (Notas de campo, 23 de octubre de 2008). 
Para Bernarda, en este ambiente de teología india es cuando surgen componentes simbólicos que manifiestan la naturaleza maya de los habitantes. Pero al preguntársele si la imposición de estas prácticas o si al presentarles "profetas" o personajes que se dice son sus antepasados desde la interpretación de la misión no representa una forma de colonización y de invención, pues no saben la historia de estos pueblos, Bernarda contestó con mucha parsimonia que parte de su cometido de pastoral indígena es darles a conocer a sus antepasados, aunque con la aclaración de que no se trata de una imposición cultural, pues "ya los conocían, sólo que se les ha olvidado con el tiempo y con el contacto con la ciudad" (Bernarda, entrevista, 2008). Asimismo, explicó que los indígenas han olvidado sus formas culturales, que las han perdido, pero cuando los agentes de pastoral les empiezan a presentar de nuevo el altar maya, las profecías mayas y sus profetas, mitos mayas y otros elementos, ellos comienzan a recordar, como "algo que tienen dentro que está dormido y nosotros lo despertamos y empieza a vivir de nuevo en sus corazones" (Bernarda, entrevista, 2008).

Después de tales eventos, producto del registro etnográfico, se trató de aclarar otros aspectos como el significado del jbankilal y su origen, pues es claro que no en todas las comunidades tojolabales se usa y que desde la práctica pastoral de la Misión de Guadalupe se promueve, por lo menos por los agentes de pastoral o unos más que otros. $\mathrm{Al}$ respecto, una misionera franciscana y el coordinador de reciente ingreso a la Misión de Guadalupe explicaron que está presente entre los tsotsiles y tseltales, y que involucra todo un ritual de preparación que no se relaciona con el cristianismo, pues para la molienda de ese tabaco antes de que se seque se debe conseguir que un bebé o la esposa de un principal 
lo orine y así pueda utilizarse en la ceremonia (Notas de campo, 28 de octubre de 2008).

El jbankilal, o el hermano mayor, representa una figura de respeto para muchas culturas indígenas de la zona. Desde la perspectiva de algunos tsotsiles a quienes se les preguntó, debe consumirse cuando se tiene una preparación previa, no cada que vez que se siente pesadumbre o cada que se termina alguna actividad, como lo hacía la misionera. Esto se corrobora con una ceremonia específica de un encuentro de diáconos que se celebró días antes del curso de catequistas en la comunidad de Nuevo Guadalupe, cerca de Comitán, Chiapas. Aquí los indígenas de diferentes grupos étnicos (tsotsiles, tojolabales, tseltales, choles y kanjobales) comenzaron a quemar copal, a juntar la juncia ${ }^{22}$ para tapizar el suelo de la ermita y a tocar sus instrumentos, como tambores y arpas, durante un tiempo muy prolongado en lo que se alcanzaba un estado de trance a partir del cual se lograba un nivel de espiritualidad tal, que cuando ya se tenía preparado el altar maya y la ceremonia al interior de la ermita se podía repartir el jbankilal. ${ }^{23}$

${ }^{22}$ En esta región la juncia es el follaje de las coníferas que se recolecta y dispone sobre el piso para crear una especie de alfombra verde. Tiene, además, un significado ritual para los grupos mayenses. Evidentemente, aquí juncia no es la hierba cyperus rotundus que crece alrededor de $15 \mathrm{~cm}$ y que se tiene como una de las que más afecta las cosechas.

${ }^{23}$ En este encuentro de diáconos, el registro etnográfico recoge una música monótona y tediosa que duraba mucho tiempo, por lo menos más de dos horas, mientras cada grupo con sus rituales, siendo los tsotsiles los más visibles, se purificaban antes de la ceremonia que se llevaría a cabo en la ermita ante el altar maya, para estar preparados y, entre otros aspectos, se consumía el jbankilal. Fue en ese encuentro cuando se pudo comprender el origen de este producto, que no era sólo tabaco y sobre todo que al mencionar al hermano mayor no se aludía a Jesucristo, sino que esto era una interpretación del cristianismo (Notas de campo, 28 de octubre de 2008). 
Después de estos eventos y el enfoque en elementos como el jbankilal, se advierte que la teología india cristiana tiene un propósito en relación con la fusión, encuentro y asimilación de la religiosidad entre culturas indígenas y el cristianismo. Es claro que hay elementos que se han forjado a través del sincretismo, pero en muchos casos, como los de este encuentro bajo la idea de teología india cristiana, lo que destaca es la reinterpretación de ciertos componentes y prácticas desde la visión cristiana.

A partir de esta última idea, es importante comprender la forma en que se reinterpreta la esencia y cosmovisión de los pueblos indígenas que desde el cristianismo debe rescatarse o despertarse, en el entendido de que esa cosmovisión y referentes culturales están dormidos. A través del material etnográfico se tiene buena parte de la respuesta y se relaciona con un proceso, en cierta medida educativo y/o de adoctrinamiento, que se tratará de abordar en el siguiente subapartado.

\section{La acción pastoral en la teología india cristiana, ¿una forma de adoctrinamiento?}

En el texto de Alicia Barabas sobre teología india en el pueblo mazateco en Oaxaca hay una cita de una entrevista que hizo a una indígena en Huautla, que merece la pena transcribir aquí:

[...] la Teología de la Liberación sólo le hace conciencia al pueblo de sus condiciones de opresión, pero no respeta la teología que ya está en los pueblos indígenas, piensan que la teología sólo viene de Europa, que aquí la gente tiene creencias, pero medio 
chuecas, creen en Dios pero no en el Dios verdadero (Barabas, 2015, pp. 14-15).

Muchas de las características percibidas por los pueblos campesinos e indígenas en relación con la teología de la liberación se relacionan con una suerte de exclusión, incluso sienten violencia hacia sus creencias; la imposición y hegemonía de la teología eurocentrista. La teología india cristiana busca, en oposición a esto, construir una Iglesia autóctona "reelaborando la cosmovisión y ritualidad indígena en términos del catolicismo" (Barabas, 2015, p. 15). En Oaxaca dicha teología tiene presencia en grupos indígenas como los mazatecos, promovida por la orden de los josefinos con la idea de recuperar a través de la evangelización la religión mazateca y así crear una Iglesia autóctona. En esa zona la acción pastoral tuvo éxito gracias a programas o misiones que formaban promotores y catequistas, así como grupos de base o comunidades eclesiales de base que llegaron a ser muy activas.

El proceso de inculturación del evangelio era un tipo de adaptación o búsqueda de semejanzas entre la teología mazateca y la cristiana que, podría decirse, no sólo se trataba de vestir la palabra de Dios de un ropaje mazateco, sino de entablar un diálogo intercultural consciente y de respeto hacia las culturas indígenas. Alicia Barabas habla del gran logro de años de trabajo pastoral de los josefinos con la gente mazateca, lo que se ve materializado en una obra llamada Elementos rituales mazatecos, de 1998, donde se describen creencias y prácticas de este pueblo. La crítica que esta antropóloga formula es que se trató de una clase 
de "sincretismo inducido" que no consiste en una relectura del cristianismo desde la cosmovisión mazateca, sino:

[de la] relectura de la religión y ritualidad de la colectividad mazateca hecha por los josefinos y catequistas bajo los principios del cristianismo, sistematizada en un libro y numerosos nuevos rituales, e imbuida a los chamanes de cada familia en sucesivos actos de proselitismo como un nuevo cuerpo de creencias (Barabas, 2015, p. 17).

Barabas se concentra en describir de forma analítica una clara acción selectiva de elementos rituales, una reinterpretación ritual, cultual y religiosa, pero desde los preceptos cristianos, lo que en stricto sensu no es inculturación, y define las características de una teología india cristiana y no de una teología mazateca per se de la que seleccionan, lo que implica una exclusión de aspectos propios de la cosmovisión mazateca, la reelaboración de otros compatibles con el catolicismo y la implantación de nuevos rituales y conceptos teológicos que hacen la diferencia entre las iglesias autóctonas y las nativas (Barabas, 2015, p. 29).

La recuperación o rescate cultural, como se observa en el ejemplo de los mazatecos de Oaxaca, aún hoy llega a oírse en boca de muchos agentes de pastoral en contextos indígenas, sobre todo en áreas donde las comunidades presentan una situación de gran desplazamiento cultural. Es evidente que el fortalecimiento cultural es una estrategia indispensable con el fin de lograr mayor cohesión social y con ello fortalecer la identidad de la comunidad. Sin embargo, es delicado intervenir o actuar con proyectos de este tipo, porque es sencillo caer en la reinterpretación cultural, 
más aún en el aspecto religioso, como ya se observó en el caso mazateco expuesto por Barabas y con el caso de los tojolabales y kanjobales a través del altar maya y el jbankilal.

Algunas misiones evidencian la necesidad de poner en marcha proyectos de rescate cultural en los encuentros de teología india cristiana, así como en los proyectos particulares que cada misión tiene con los pueblos indígenas. En el curso de catequistas en Rizo de Oro, Chiapas, se expusieron estrategias de enseñanza de esa cultura de la que no son conscientes o que se ha perdido entre los tojolabales y kanjobales, y que describe la intervención que la Iglesia lleva a cabo a través de sus agentes de pastoral, con el fin de rescatar al pobre y al indígena en esta perspectiva de menor de edad y de desfavorecido.

La actitud asistencialista que prevalece en el discurso y acción pastoral ya es notoria con el término "rescate", que llega a atenuarse con otras palabras como "acompañamiento". El interés de las misiones en la recuperación o rescate cultural de estas comunidades es porque consideran necesario "hacer que conozcan o reconozcan sus raíces indígenas [mayas] porque refuerzan su identidad, al hacerlo, ya no hay tanta división (Torres, comunicación personal, 27 de noviembre de 2008).

El objetivo aquí es que no sólo el indígena como sujeto pasivo se deje rescatar, sino que se interese por ello; asimismo, el misionero debe involucrarse y aprender de los indígenas. El misionero religioso Gerardo Torres menciona que:

[...] realmente lo que se ha ido reflexionando con los hermanos son aquellas cosas que les dan vida, aquellas cosas que, es decir, si tan sólo podemos decir que somos como acompañantes del proceso 
en cuanto ayudamos, como proponiendo, como un caminar y que hemos ido aprendiendo también cómo es ese caminar, digamos como una metodología indígena que hemos aprendido también en el camino para que ellos puedan profundizar realmente cómo es su cultura, desde sus maneras de ser también, de cómo invocan, desde ahí vas viendo (Torres, comunicación personal, 27 de noviembre de 2008).

Un serio problema de esta metodología de rescatar y aprender la cultura indígena es que está llena de esencialismos, es decir, hay una actitud y un discurso de idealizar lo indígena y condenar lo no indígena en una suerte de nostalgia imperialista (Rosaldo, 1991) o culpa histórica en la que el mestizo o caxlán asume ser parte de la "raza" que despojó, vejó y marginó al indígena. Lo que refuerza estas ideas es la recurrencia a un pasado glorioso.

En el mundo maya, que ha adquirido gran popularidad desde hace años con la imagen creada de ellos como matemáticos y astrónomos, hay un buen ejemplo de la mencionada idealización. Se asume que los tojolabales, kanjobales, tseltales, entre otros, por el hecho de ser mayas -aunque esta clasificación responde a algunas características lingüísticas-deben tener las cualidades de sus antepasados del pueblo de Palenque o de Chichén Itzá, aunque ni siquiera se tenga la certeza o un estudio serio que demuestre su vinculación.

He aquí un material utilizado por los agentes de pastoral en el curso de catequistas en Rizo de Oro, Chiapas, descrito en el apartado precedente. 
Imagen 2. Reproducción del tablero de la Gruz Foliada del Templo de la Gruz Foliada en Palenque, Chiapas, hecha por los agentes de pastoral de la Misión de Guadalupe. Esta imagen representa la entronización de K'inich Kan Bahlam por su padre fallecido K'inich Janahb Pakal.

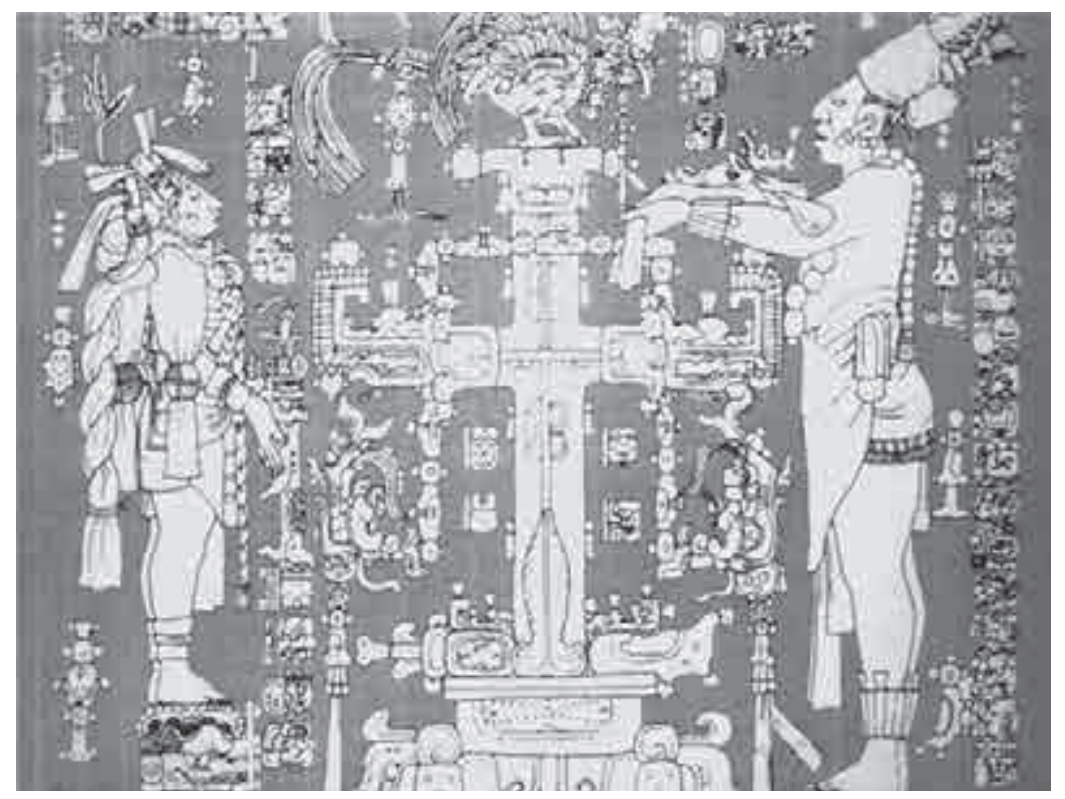

El material aquí expuesto debía reproducirse en lienzos de manta de 3.5 metros cada uno para formar un rompecabezas y llevar a cabo una actividad con los indígenas y los agentes de pastoral, que consistía en completar el rompecabezas mientras los indígenas iban viendo algo con lo que se sintieran identificados. El resultado con claridad fue que nunca hubo una identificación con la imagen, incluso, fue difícil armarlo porque no sabían ni le encontraban sentido. 
El contenido de la imagen era K'inich Janahb Pakal cuando entrega a su hijo un estandarte que significaba la cesión del mando de su reino, pues Pakal ya había muerto. Como lo señaló el arqueólogo Horacio Olivares cuando se le comentó sobre este suceso:

Imagina lo complicado que ha sido para la arqueología definir escenas de este tipo. Hablamos de ciencia aplicada para interpretar esto. ¿Crees que sin la información histórica y arqueológica, por ejemplo, de Palenque ni mucho menos la información histórica de los tojolabales, su interpretación con estas actividades es adecuada, pertinente? Por supuesto que se reinterpreta y se folcloriza. En eso se cae (Olivares, comunicación personal, 2010).

Por otro lado, se mostró durante la actividad una imagen más que es adaptación de la cesión de poder de Pakal a su hijo, pero con elementos actuales, que incluye mestizos, con el objetivo de dejar un mensaje o enseñanza de tipo moral, como se observa en la siguiente figura. 
Imagen 3. Reproducción elaborada por los agentes de pastoral de la Misión de Guadalupe que emula a la imagen de la Gruz Foliada con elementos actuales: un empresario, una familia de campesinos pobres explotados por el empresario y una serie de elementos de explotación característicos de un modelo económico neoliberal y de la globalización, como los logos de las dos televisoras más importantes de México, y en el extremo izquierdo aspectos que reproducen lo característico de la ciudad, como el drenaje, una rata, el dinero, fábricas, productos procesados, etcétera.

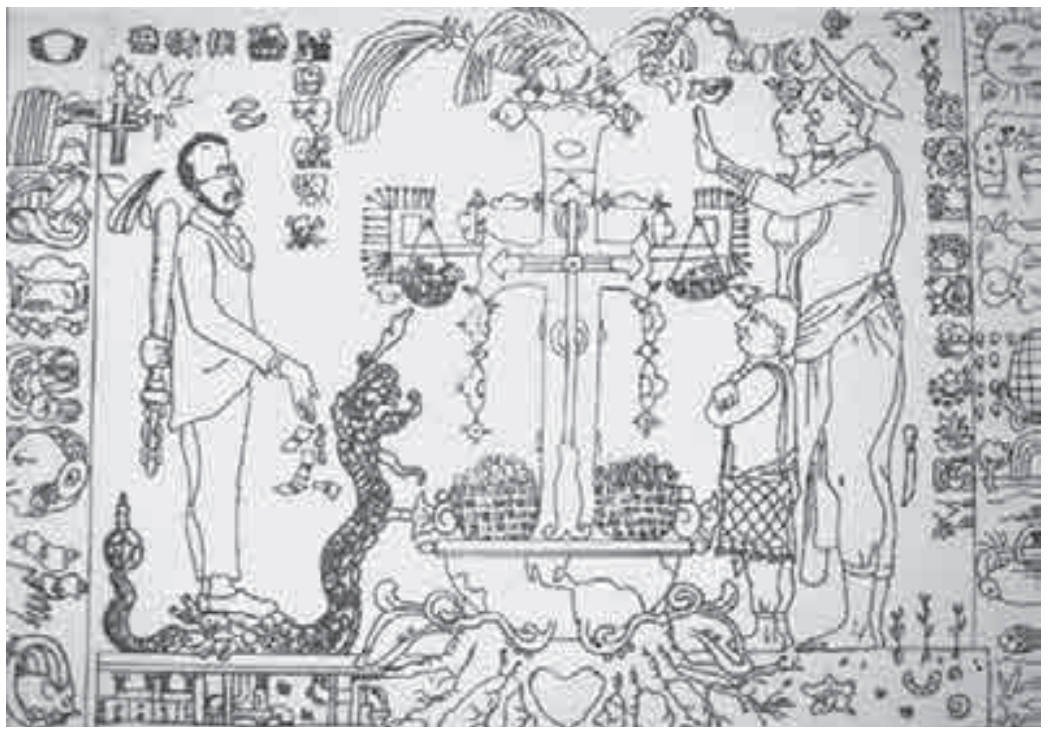

La adaptación de esta imagen consiste en un mestizo o caxlán que ocupa el lugar de Pakal, vestido con un traje y arrojando dinero, aunque sostiene una suerte de cachiporra o mazo detrás de él, y en lugar del hijo de Pakal se ve a una familia indígena que trata de interactuar con el caxlán, pero que ignora su carácter traicionero. Es muy clara la nostalgia imperialista de esto que alude al carácter de un mestizo como poco confiable y opresor. El mestizo 
o caxlán carga con la culpa de la historia que se ha desarrollado a lo largo de siglos y que heredó de los ibéricos establecidos en la Nueva España, a partir del movimiento de Independencia en el siglo XIX.

El registro etnográfico en Rizo de Oro, cuando se presentaron estas imágenes y se realizó la actividad de formar el rompecabezas, indica que los tojolabales ahí reunidos no sabían quién era Pakal ni el sentido de mostrarlo o exponer una segunda imagen con un caxlán en lugar de Pakal. Pero la percepción de los agentes de pastoral era distinta. Cuando se abordó lo ocurrido en esta dinámica en Rizo de Oro con el coordinador de la Misión, Juan Carlos Robles, éste contestó:

Necesitas un referente, de dónde vienes y qué elementos te sirven para entender el mundo y transformarlo. Lo único que estamos haciendo al hacer esa recuperación, es decir, "ustedes tienen unos referentes bien cercanos", o sea, bien cercanos hablando de tiempo porque hace muy poco que los han estado perdiendo más fuertemente... no que sean los únicos, pero son los que les pertenecen por cuestiones históricas y por cuestiones de ellos mismos... tú escuchas a los hermanos cómo ocupan su lenguaje en español, pero que detrás de eso están todos los valores y cosmovisión diferente, ¿no?, aunque la lengua ya la hayan perdido, todavía tienen esos marcos de referencia interiorizados que pertenecen a esa cultura. Entonces, el decir recupera eso es: "esa es tu base desde donde puedes entender el mundo y que de por sí así lo entiendes, lo que pasa es que no lo comprendes (Robles, entrevista, 2008). 
El problema de una imagen como la que presentaron en el curso es que los indígenas la perciben como una realidad de la ciudad y de la gente de ciudad, es decir, el personaje con traje y corbata arrojando dinero, etcétera. La intención es representar al mestizo usurero, malvado, corrompido, al político o al finquero, pero en el fondo consiste en una interpretación de los agentes de pastoral con una intención como la que menciona el coordinador de la Misión. Sus palabras en el fragmento de la entrevista que se expone encierran muchos juicios de valor e interpretaciones, pues habla de una memoria histórica (referentes) que tienen los indígenas que están perdidos, y ellos como misioneros pretenden rescatarlos. Además, el modo de hacerlo es a partir de una actividad en donde se superpone arbitrariamente la figura de un ciudadano mestizo a la de Pakal para conducir a la reflexión, pero que dista mucho del contexto, la cultura, la historia de los pueblos indígenas a los que se dirigen.

La idea de rescate cultural o la intención de los agentes de pastoral con esto es incentivar una cohesión cuya pérdida ha hecho que se incrementen fenómenos sociales como la migración. La agente de pastoral Bernarda expresa sobre el ejercicio y uso de las imágenes que se busca "impedir que los indígenas migren, porque eso no es conveniente para sus familias" (Bernarda, entrevista, 2008). Por otro lado, el coordinador Juan Carlos explica que la imagen y el propósito de la actividad es dejar claro que la migración afecta a las familias e implica riesgos muy grandes para el migrante, pero también hay riesgos cuando el migrante regresa porque "introducen una serie de cosas que aprendieron y traen de los lugares en donde trabajaron que se refleja en las 
costumbres que transforman y que van acabando con las formas culturales mayas" (Robles, entrevista, 2008).

En esencia, se puede decir que en la labor pastoral que se muestra en los ejemplos expuestos, la teología india cristiana no consiste en una serie de eventos aislados o encuentros en donde se practican rituales indígenas, sino también hay un proceso de adoctrinamiento con el que se intenta revertir o generar valores y rasgos que se manifiesten en una práctica ad hoc a las culturas indígenas. El problema es que se sigue interpretando desde una perspectiva cristiana, eurocentrista y se recrean prácticas, valores, incluso la historia y la memoria misma de un grupo cultural.

Lo que llama la atención es que no sólo hay una manera de adaptar el cristianismo a las demás culturas y la selección de algunos elementos autóctonos para integrarlos a una práctica religiosa "cristiana-indígena", sino en estas formas de reinterpretar la cultura y la religión surgen posiciones esencialistas que conciben a la cultura como algo estático y que no debe cambiar. Es clara la preocupación de algunos pastorales ante los cambios y el desplazamiento de elementos culturales en las comunidades que devienen en una desestructuración familiar y social, como resultado de fenómenos como la migración o la dependencia de un estilo de vida, productos y servicios de la ciudad, incluyendo los programas sociales gubernamentales. Sin embargo, en la primera década del 2000 se observó una inquietud constante por la "pérdida" de la cultura que debe rescatarse. Aún hay una concepción del indígena como un ser pasivo, como menor de edad que debe ser representado y liberado.

A inicios de 2010 esto se fue transformando hasta repensar la cosmovisión indígena y, sobre todo, empezar a situarse y ser 
conscientes del papel que el sujeto, en este caso el agente de pastoral, desempeña en los contextos indígenas. En la teología india cristiana se empieza a observar que el rol que los agentes de pastoral llegan a tener debe tratarse con cuidado y atenderse desde la comunicación y la lengua. La transformación que experimenta una acción pastoral situada busca frenar la práctica de reinterpretación, representación y, como advirtiera Raúl Fornet-Betancourt, pensar al otro de otra forma (Fornet-Betancourt, 2005). Esto se desarrollará en el próximo capítulo, pero es importante comprender que lo que inició a mediados de la década de 1960 hasta bien entrada la del 2000, esto es, la transformación en la ideología y praxis pastoral ha ido de la liberación a la comprensión y reconocimiento del otro. Sin embargo, la tendencia en la Iglesia católica - a la par de un ritmo que también las Ciencias Sociales han seguido desde 1970- es situarse, o sea, reconocerse uno mismo como investigador, como agente de pastoral o como activista en el contexto en que se produce un determinado fenómeno social y asumir el papel que se juega ahí. Pero también la participación del otro, es decir, la participación de la sociedad que se estudia, evangeliza o representa, dependiendo del papel que se desempeñe, es un aspecto que destaca y la razón principal por la que se habla de gobernanza, concepto que no se ha tratado desde la visión religiosa y mucho menos desde la pastoral indígena. 


\section{CAPÍTULO 3}

\section{LA PASTORAL INDÍGENA EN LA GOBERNANZA}

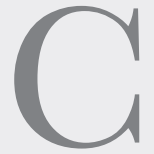

omo se planteó en la introducción de esta obra, cuando se habla de gobernanza se asocia este término con políticas públicas eficientes y transparentes, así como con la idea de dirección política, pero los responsables de esta dirección política no están adscritos únicamente al Estado, sino también a los organismos internacionales como Naciones Unidas, el Fondo Monetario Internacional o el Banco Mundial. No obstante, en el afán de pensar en la gobernanza como un concepto que llegue a expresarse en una práctica más equilibrada, es decir, que el poder no sólo se concentre en el Estado o en los actores económicos, se requiere la participación de la sociedad civil.

Estas posturas ya se expresaban desde 1990. Incluso antes se hablaba de gobernanza a partir de dos ejes contenidos en la definición de Luis Fernando Aguilar:

La acción del gobierno es necesaria pero insuficiente para la tarea directiva de la sociedad y, por consiguiente, lo importante y decisivo es crear un nuevo proceso de gobernar más que dotar al gobierno con todas las capacidades requeridas para dirigir a la sociedad (Aguilar, 2014, p. 15). 
Desde la perspectiva de Aguilar, se puede comprender que el surgimiento de la noción de gobernanza está más relacionado con la insuficiencia que con la ineficacia o la propuesta de otras formas de dirigir, empezando por la inclusión de nuevos actores. En este caso, existe una necesidad de que la sociedad civil y otros agentes se involucren en la toma de decisiones para resolver una problemática específica, pues el Estado está rebasado.

En el mismo tenor, Rocío Rosales y Ludger Brenner conciben la gobernanza como "un proyecto o proceso para la definición democrática de objetos de interés público y la implementación participativa de medidas para alcanzarlos" (Rosales \& Brenner, 2015, p. 8). Esta definición es interesante porque alude a un proceso, a una acción continua que rompe con la tendencia de sólo describir o identificar escollos. La gobernanza, entonces, implica una sociedad civil activa y una postura que no busca derrocar la figura del Estado, sino complementarla; destaca de nuevo la idea de un Estado o las políticas de un gobierno que no son suficientes y que deben enriquecerse.

En relación con la intervención de los grupos religiosos y la acción pastoral, la presencia de la Iglesia católica latinoamericana de izquierda y su compromiso con la gente se fue concretando, desde 1960, en una ideología y obra concebidas bajo el nombre de teología de la liberación que con el tiempo se fue matizando sin dejar de lado el objetivo de liberación del oprimido y opción por el pobre, pero con acciones que si bien siguen identificándose en la actualidad con una tendencia de izquierda, se piensa en otros métodos más dirigidos al diálogo y no - por un lado- al adoctrinamiento ni-por el otro- a la subversión y ruptura con instancias como el Estado u otros agentes. 
En este proceso, un aspecto que debe tomarse en cuenta es que la sociedad civil (en este caso los pobladores de las comunidades indígenas y campesinas) era cada vez más partícipe, como se ilustró en el capítulo anterior con el Congreso Indígena en San Cristóbal de Las Casas. Esto no significa que ya podía hablarse desde ese momento de gobernanza, por lo menos no con esa palabra, pero sí es conveniente destacar que uno de sus actores principales - esto es, la sociedad civil- ya desde entonces es protagónico en espacios que, por polémicos o tensos que parezcan, son propicios para generar una dinámica de diálogo con otros como el Estado o la Iglesia.

La anterior es una de las razones por las que en la acción pastoral de hoy, después de un proceso de décadas de transformación y una mayor independencia por parte de la sociedad civil (indígena), puede hablarse también de gobernanza como un escenario, incluso una práctica, en un entorno sociorreligioso en donde han trascendido los métodos clásicos de evangelización y se han concentrado más en acciones prácticas fundamentadas en el análisis de la realidad de los pueblos indígenas, en su lucha por ser reconocidos, ser autosuficientes y lograr un estatus de diálogo con otras instancias, y no subyugados por ellas.

La gobernanza, según las definiciones que se han expuesto en este libro, es resultado de una serie de cambios que, como la pastoral, también han acontecido en las últimas décadas. Así como se asume que existe insuficiencia en el Estado para resolver problemas complejos y, por lo tanto, corresponde a otros organismos y agentes sumar esfuerzos para resolverlos, la realidad es que hay un actor principal en este escenario que es la sociedad civil y que ha sido excluido de diversas maneras. 
En el caso de los pueblos indígenas no es nueva la idea de infantilizarlos, es decir, de percibirlos como menores de edad y, por lo tanto, incapaces de afrontar su realidad. El papel de los religiosos misioneros desde el siglo XVI -y en muchos casos junto con activistas de ONGs en nuestros días- ha sido representarlos, hablar por ellos, determinar cuáles son sus problemas y cómo atenderlos. Esta verticalidad al actuar también ha sido parte de una dinámica de gobernanza, mediante las acciones y principios de organismos nacionales e internacionales no gubernamentales. Lo que Rosales y Brenner definen como buena gobernanza es una serie de normas que los agentes (sociales, económicos, políticos, etcétera) deben asumir durante su participación en las decisiones públicas para fortalecer su legitimidad y efectividad (Rosales \& Brenner, 2015), pero en la práctica la sociedad civil pareciera seguir al margen.

En suma, más allá de los pueblos indígenas, la sociedad civil (urbana, campesina, mestiza, afrodescendiente, femenina, entre otras clasificaciones) tiende a ser representada por organismos nacionales e internacionales, lo que paradójicamente significa su exclusión de lo que se pretende defender o favorecer ante un Estado rebasado por la coyuntura global en diferentes áreas: medio ambiente, migración, violencia, seguridad, discriminación, derechos culturales, entre otros temas. Esta situación tiene su origen en el siglo XIX. Gran parte del discurso de integración, de fraternidad e igualdad en derechos y la democracia surgió con la ruptura del llamado ancien régime de la Revolución francesa de 1789. A lo largo de la referida centuria, el pensamiento liberal que tiene sus bases en esta Revolución francesa fue en aumento y se extendió por Europa y el mundo. 
Hoy, la democracia y su discurso sufren una situación crítica al igual que la estructura del Estado-nación. ${ }^{24}$ La idea de democracia y los espacios de la sociedad civil han sido secuestrados de tiempo atrás por grupos que concentran el poder y que tienen la función de representar la voluntad del pueblo, como los partidos políticos o el Estado mismo, en lugar de que estén en manos de la sociedad.

Sin embargo, esto que parece ser un síntoma muy antiguo de crisis y que se ha agudizado en las últimas décadas, se advierte con mayor claridad frente a problemas globales que el Estado es incapaz de resolver. Es el caso del deterioro ecológico, el fenómeno migratorio, la desigual distribución de la riqueza, el manejo de información o el acceso a la educación. En estos asuntos, más que el Estado, la principal participación se concentra en organismos internacionales como el Fondo Monetario Internacional, la Organización para la Cooperación y el Desarrollo Económico, el Banco Mundial, etcétera.

En este horizonte en el que dichos organismos internacionales actúan, se habla también de gobernanza. Para Daniel Innerarity (2013) los principios básicos de una gobernanza global son la democracia, el humanismo y la justicia. Es importante, al

${ }^{24}$ Es importante señalar que la figura del Estado-nación desde la óptica que se pretende expresar es una forma de alzamiento, "como otra forma distinta y distante del antiguo régimen, en donde conceptos como democracia [y] estado de derecho adquieren fuerza en una nueva dimensión cobijados a la sombra de un sistema donde la laicidad reconfiguró las relaciones entre los agentes de una nueva sociedad y van a dar forma al Estado-nación, cimentado en la nación y su construcción del nacionalismo; la representatividad y su sistema de cámaras; y desde luego la creación del discurso a partir del antropocentrismo representado por el ciudadano y con él la ciudadanía [...]” (Hernández, 2018, p. 14). 
respecto, pensar también en un contexto distinto al del Estado nacional del que nos hemos habituado a creer que ahí se construye la democracia y los principios de justicia. Al parecer, dice Innerarity, la globalización está despolitizada y las entidades internacionales resultan fundamentales para la solución de ciertos problemas políticos, pero no son estructuralmente democráticos.

El inconveniente de ver en tales organismos a los representantes de una sociedad o el bienestar de la sociedad frente a la "insuficiencia" del Estado es justo la idea y el verticalismo que con dicha representación se proyecta. La noción de gobernanza conformada por estos actores internacionales portavoz de la sociedad civil y sus demandas está rezagada en términos teóricos, pero persiste en la práctica hasta el día de hoy y siguen la lógica de un modelo predominante como el neoliberalismo. Por esta razón, dice Innerarity acerca de las justificaciones funcionales y apolíticas de estos organismos internacionales fundados en países nucleares o de "primer mundo", "no es aceptable que unas élites de unos pocos países, excluyendo a las opiniones públicas nacionales y globales, condicionen las políticas nacionales de otros países (Innerarity, 2013, p. 14).

Desde esta perspectiva, el panorama de la gobernanza global y/o la "buena gobernanza" debe analizarse, pues a pesar de la creación de organismos internacionales que se enfocan en dar solución a problemas globales y locales de diversa naturaleza, y que en muchos aspectos sí palian los efectos negativos sobre la sociedad, se mantiene todavía una situación deplorable y contrastante entre países ricos y pobres, o dentro de un mismo Estado la desigualdad y la exclusión es alarmante. En cierta forma, la explicación de esto es que, desde una visión global, apolítica y desde las 
élites, los organismos internacionales no sólo tienden a incurrir en prácticas asistencialistas, sino también desconocen los problemas reales de una sociedad; así, podría decirse, ésta queda excluida.

En este sentido, cuando se habla de exclusión deben contemplarse distintas facetas o aristas. Se excluye cuando se ignora a determinados grupos o individuos dentro de una colectividad por sus características físicas y/o culturales, incluso cuando se menoscaban los problemas de esos grupos sociales; pero también hay exclusión cuando se interpretan los problemas o se habla por la sociedad misma. Este es el caso de muchos organismos internacionales y nacionales o del Estado mismo. A lo anterior se hace referencia también cuando se asume que la democracia está en crisis, pues una sociedad civil con derechos inalienables y libre, como versa en el discurso democrático, no debe sufrir ningún tipo de exclusión, sea velada u oculta. ${ }^{25}$

Juan Carlos Monedero y Antoni Domènech explican en diferentes situaciones que hacer a un lado a la sociedad civil no sólo implica un discurso falso de democracia, sino que se debe recuperar el sentido de democracia del secuestro de las élites políticas y empresariales para que regrese a manos de la sociedad civil (Monedero, 2017; Domènech, 2004). En otras palabras, la democracia como parte del discurso que viene desde el siglo XIX está en manos

\footnotetext{
${ }^{25} \mathrm{Al}$ respecto, es interesante la opinión de Luis Fernando Granados cuando usa la noción de pueblo o, en palabras más actuales, la sociedad civil, que en distintas épocas ha tenido el papel de robustecer el discurso democrático. Granados advierte que la idea de "pueblo", pensando en la sociedad civil, es una suerte de ideal o figura discursiva que en realidad nunca ha sido partícipe en los movimientos sociales y políticos de los periodos revolucionarios y liberales, sino como una especie de masa, es decir, se trata de un ente visible en el discurso histórico y político, pero invisible y excluido en la realidad (Granados, 2016).
} 
de las altas esferas políticas representadas por el Estado, los partidos políticos - que más que hablar en nombre de la población, forman parte de la estructura del Estado- y las élites económicas conformadas por los empresarios. En este vaciamiento de la democracia, su actor central ausente, es decir, la sociedad civil, debe revertirse y apropiarse de los espacios que le corresponden. ${ }^{26}$

A propósito de la sociedad civil u organizaciones de ella (OSC), de acuerdo con Hernández Legorreta (2018), son importantes en este proceso de generar o hacer funcional la democracia, pues expresan la relación de intereses entre los principales involucrados y el medio en el que operan, es decir, los intereses y el contexto de la sociedad civil misma. Sin embargo, la estructura jerárquica de esta noción de sociedad civil se vislumbra, pues son estos organismos y ONG los que representan o hablan por el pueblo. De hecho, el pueblo mismo no es concebido en la praxis como la sociedad, sino una figura como aquella a la que alude Granados, que sigue siendo retórica y discursiva.

Desde el momento en que la acción e intervención de la sociedad civil en la toma de decisiones a nivel político, económico y social es uno de los principios de la gobernanza, debe considerarse que esa sociedad civil participante son muchas de las organizaciones nacionales e internacionales, pero no los individuos que conforman la sociedad como tal. Esto implica la necesidad,

\footnotetext{
${ }^{26}$ Cuando se habla de sociedad civil en la actualidad debe entenderse como la "[...] suma total de aquellas organizaciones y redes que se ubican fuera del aparato estatal formal, la cual incluye toda la gama de organizaciones tradicionalmente conocidas como grupos de interés, entre los cuales se encuentran las organizaciones no gubernamentales, organizaciones no lucrativas, asociaciones cívicas, asociaciones voluntarias, etc." (Hernández Legorreta, 2018, p. 18).
} 
no de relativizar, pero sí de entender que la gobernanza no puede ser una definición homogénea y debe buscar que la sociedad civil no siga al margen de los mecanismos de decisión en los que el Estado, grandes organismos y actores económicos operan.

Ahora bien, la gobernanza ha pasado por una transformación en su significado y praxis. El concepto al que aluden Rosales y Brenner como "buena gobernanza" se centra en diseñar y ejecutar políticas públicas eficientes y fomentar la participación de la sociedad civil, pero no explicita su integración en la resolución del problema. En este orden de ideas, Luis F. Aguilar advierte que la gobernanza se clasifica según la relación que tengan el gobierno y las organizaciones de la sociedad. Así, podría hablarse de "vieja gobernanza" cuando ésta proviene desde y por el gobierno; de una gobernanza que se caracteriza por una dinámica de "autogobierno", 27 es decir, que es la sociedad la que la pone en marcha al margen del gobierno, y una última que, en una dinámica de diálogo y consenso entre la sociedad, el gobierno y demás actores, se lleva a cabo y se denomina "nueva gobernanza" (Aguilar, 2015).

Es la definición de nueva gobernanza la que en apariencia marca a esta época en la que la sociedad civil es más partícipe, incluyendo a las comunidades indígenas. ${ }^{28} \mathrm{El}$ verticalismo de la buena gobernanza y, en gran medida por el dominio de los organismos internacionales como el Banco Mundial o Naciones

\footnotetext{
27 En el sur de México, en específico en comunidades indígenas y campesinas, se habla de comunalidad para el caso de Oaxaca o de autonomías, en el de Chiapas.

28 Como se abordará más adelante, en este contexto de gobernanza o de nueva gobernanza, las sociedades indígenas y campesinas actúan por sí solas, luchan por su reconocimiento y por abrir espacios de diálogo con instancias gubernamentales y no
} 
Unidas, entre otros, aún segrega la colaboración de otros actores durante la toma de decisiones para el cambio de ciertas situaciones. Mientras la buena gobernanza se caracteriza por la participación, legalidad y transparencia en la resolución o la toma de decisiones, la nueva gobernanza hace énfasis en la idea de asociación y cooperación entre los agentes.

Es importante aclarar que no se busca estar en contra del Estado ni destruirlo, sino dialogar y trabajar en consenso y en una mecánica cooperativa que genere un cambio sustancial de las problemáticas a resolver, ya sea del medio ambiente, la pobreza material, la equidad de género, la justicia, entre muchos otros temas en los que se enfoca y en los que se va concentrando la gobernanza.

Ahora bien, así como podemos observar la gobernanza en una gran diversidad de temáticas y dimensiones (global-local), como el medio ambiente, la migración, las contiendas electorales, los derechos humanos, entre otros, también es importante pensarla en contextos como el sociorreligioso. Desde el momento en que se trata de un concepto, pero también praxis que está en constante (re)construcción y (re)definición, las posibilidades de desarrollarlo son numerosas. Por esta razón, en este capítulo se pretende explorar el entorno sociorreligioso en relación con la gobernanza, en específico en la pastoral indígena. Los pueblos

gubernamentales en donde se propongan soluciones a sus problemas. En este contexto la Iglesia católica, a través de la acción pastoral, se involucra, acompañando y asesorando desde el momento en que reconocen y comprenden las problemáticas de cada sociedad con la que trabajan y proponen iniciativas que van desde sociedades cooperativas, talleres, implementación de dispositivos y tecnología de, para y por el pueblo. Se ahondará más en lo anterior cuando se toque el tema de la ecoteología. 
indígenas y los agentes de pastoral cuentan con una organización que si bien puede involucrarse con el Estado, con algunas organizaciones no gubernamentales y con la Iglesia católica, son los propios pueblos los que se organizan en busca de una mejora sustancial de su modus vivendi a través, por ejemplo, de acciones desde una perspectiva ecológica y sostenible, educación, salud, perspectiva de género, entre otros aspectos.

La pastoral indígena ya había experimentado desde hacía varias décadas una transformación a favor de atender y acompañar los problemas y preocupaciones de la realidad de estas comunidades. Es por eso que, sin perder un vínculo con el pasado liberacionista, se puede hablar de una suerte de pastoral que atiende la educación a través de la que se promueve la cultura de prevención en materia de salud, la perspectiva de género y, sobre todo, el cuidado de "nuestra casa", como el Papa Francisco llama a la Tierra en su encíclica Laudato Si', en relación con la conservación ecológica.

Quizá de los ejemplos más adecuados para hablar de gobernanza, de la participación de la sociedad civil y de la acción pastoral es el ámbito ecológico, razón por la que en el siguiente apartado se abordará este tema a partir de las nociones y conceptos de la ecoteología como las premisas de una gobernanza ambiental y, podría pensarse, de una gobernanza de la pastoral.

\section{Ecoteología y sostenibilidad: una propuesta de gobernanza ambiental}

En la actualidad, la preocupación por el medio ambiente es cada vez mayor, pues no sólo afecta a la ecología en su acepción más 
biológica, sino también a la sociedad que depende de los recursos medioambientales. Si se piensa en la distribución de los bienes naturales, la intranquilidad ecológica no sólo se concentra en la explotación del medio ambiente, sino en el reparto y explotación de ellos de forma tan desigual entre la sociedad global.

La ecología y los problemas relacionados con ella es un tema complicado que rebasa al Estado, es decir, la figura del Estado-nación en sí misma no puede resolverlos, toda vez que se trata de un fenómeno que trasciende las fronteras de un país. Así, la organización de la sociedad civil en una forma de independencia gubernamental y empresarial se ve en la necesidad de actuar aun sin contar con suficientes apoyos legales, financieros, organizativos, entre otros, que proporciona el Estado.

El papel del gobierno de mantener la armonía social y dotarla de un estado de bienestar depende de elementos exógenos, como la ayuda de otras instancias gubernamentales y organismos internacionales, pero también de la sociedad civil. Sin embargo, esto se complica cuando la sociedad en sí misma está en una situación de vulnerabilidad, sobre todo con el tema de la pobreza, que en lo que respecta a los pueblos indígenas es un factor presente y creciente. El problema es que no se puede paliar con las herramientas y recursos que posee el gobierno, es claro que la mano de otras instancias resulta indispensable y, entre ellas, la acción de los organismos religiosos ha sido destacable en las últimas décadas, sobrepasando la acción pastoral asistencialista que por tradición habían llevado a cabo.

Para comprender en esta tónica a la acción pastoral es necesario entender la naturaleza de la Iglesia católica, lo que conduce a una dificultad mayor, pues se trata del Status Civitatis Vaticanae,

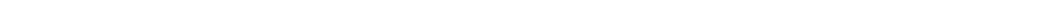


es decir, un Estado independiente que goza de una jurisdicción extraterritorial, con una forma de gobierno monárquico absolutista, en el que el Sumo Pontífice tiene plenitud de poderes en el Legislativo, Ejecutivo y Judicial.

La Iglesia, sin embargo, también funge en otros contextos -a través de organizaciones no gubernamentales- como benefactora y defensora de las necesidades de los sectores en condiciones desfavorables. Es por ello que muchas de las donaciones, distribución de víveres, ropa y otros recursos a poblaciones que han sufrido alguna desgracia o que se mantienen en situación de vida lamentable están vinculadas a la Iglesia, por ejemplo las que se realizan a través de las ONG en defensa de los derechos humanos, como el Centro de Derechos Humanos Miguel Agustín Pro Juárez, el Centro de Derechos Humanos "Fray Francisco de Vitoria" O.P. A.C., el Centro de Derechos Humanos Fray Bartolomé de Las Casas, el Centro de Derechos Humanos Tepeyac del Istmo de Tehuantepec A.C. o el albergue de migrantes "Hermanos en el Camino". Éstas son sólo algunas en el sur-sureste de México fundadas por la Orden de Predicadores, la Compañía de Jesús o por diocesanos. Más allá de la estructura estatal de la Iglesia católica, existen muchas acciones que se concretan en estas asociaciones civiles a favor de los más desfavorecidos. Si se considera que entre estos grupos los pueblos indígenas destacan por las características de precariedad, no es extraño que muchas de las ONG se enfoquen en grupos étnicos de esta naturaleza.

Otro aspecto que podría destacarse de la Iglesia, mejor dicho, de la acción pastoral, es que no sólo son las referidas organizaciones y la estructura estatal lo que distingue a la labor del 
catolicismo como tal, pues están involucradas personas que no son religiosas, esto es, que no han abrazado la vida consagrada, sino como seglares católicos y con la vocación expresa en el mensaje conciliar de ser misioneros laicos. Estos integrantes de las "misiones" emprenden una tarea que obedece lineamientos y acuerdos tomados desde la diócesis y, por lo general, hay un religioso que dirige la misión, pero la actividad in situ la efectúan estos laicos en contacto con una sociedad civil, en los términos definidos anteriormente, representada por los habitantes de las comunidades indígenas.

Así, la pastoral indígena y los agentes de pastoral no son necesariamente parte de esta estructura estatal, son un grupo de individuos religiosos y laicos comprometidos con la tarea de liberar, dialogar y encarnarse en el otro (indígena); trabajar a favor de la autosuficiencia de los pueblos, en busca de romper con una dependencia hacia diversos programas sociales y asistencialistas, ya sea gubernamentales o de otras organizaciones, de tal forma que los indígenas y campesinos mexicanos puedan alcanzar la autosostenibilidad. ${ }^{29}$

En esta panorámica sobre la Iglesia católica se observa su compleja naturaleza; es decir, por un lado, la Iglesia puede concebirse como un Estado o gobierno, pero también sus agentes de

29 Por sostenibilidad se entiende la forma de satisfacer las necesidades actuales sin comprometer las capacidades y recursos de las futuras generaciones, de tal forma que puede garantizarse un equilibrio entre el crecimiento económico, el bienestar social y el cuidado del medio ambiente. Ser autosostenible implica un tipo de independencia respecto de programas e iniciativas que "asisten" a los grupos sociales que pretenden alcanzar un crecimiento y mejora económicos, así como lograr un bienestar común a partir de la conservación del medio ambiente, desde su contexto y con su cosmovisión y religiosidad, la cual por lo general está muy vinculada a su entorno. 
pastoral o misioneros (religiosos y laicos), así como sus organizaciones no gubernamentales, conforman una suerte de actores sociales. Si se sigue el esquema clásico de la gobernanza, la Iglesia por sí sola representa a dos de los actores esenciales: el gobierno y el agente social. Claro que visto desde una perspectiva global.

En el contexto indígena, la Iglesia como figura gubernamental afectaría directamente a sus miembros como tal, es decir, a los misioneros, mas no al resto de los actores, por lo que su figura encaja más en el papel de actores sociales en tanto voluntarios con la sociedad civil, conformada por los pueblos indígenas y campesinos. Sin embargo, existe un tercer elemento en el esquema de la gobernanza que son los actores económicos. La Iglesia católica también cuenta con organismos que lucran para sostener la estructura eclesiástica en una clase de gran empresa, la cual también aporta recursos varios para sufragar obras misioneras. Existen congregaciones dedicadas a la educación que poseen colegios e institutos de varios niveles educativos, mismos que destinan parte de sus ganancias al financiamiento de acciones misioneras; es el caso de los jesuitas, maristas, lasallistas, escolapios, entre muchos otros.

La Iglesia católica en sí misma puede representar los tres actores fundamentales de la gobernanza, además de los que son externos a ella, como los habitantes de una comunidad rural o urbana con la que trabajan los integrantes de la Iglesia o diferentes activistas y voluntarios de otras ONG ajenas a la Iglesia misma, como se observa en la siguiente figura. 
Figura 2. Esquema de actores de la gobernanza ${ }^{30}$

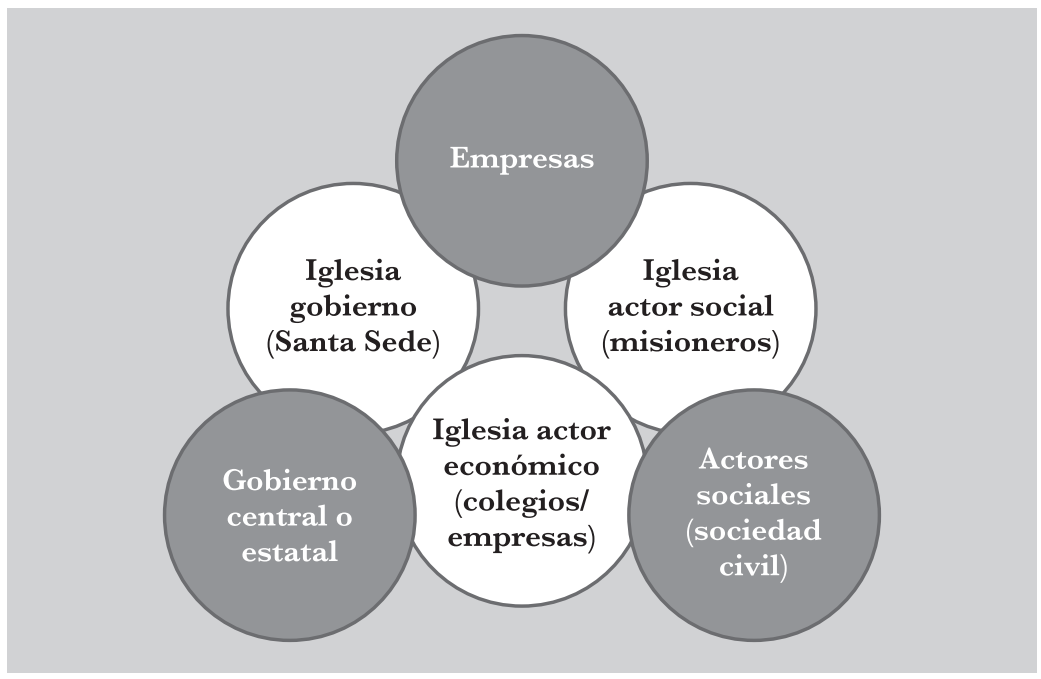

Fuente: elaboración propia.

En la figura anterior se trata de expresar la diversidad de roles que tiene la Iglesia en un esquema clásico de gobernanza con los tres actores fundamentales, pero también su relación y el papel que otros actores ajenos a ella asumen dentro de esta práctica de gobernanza, como la sociedad civil conformada por los habitantes

30 A diferencia de la Figura 1, aquí se exponen los actores fundamentales de la gobernanza (sociales, económicos y el Estado) a la par de los papeles que la Iglesia también desempeña y que se divide en los tres tipos de actores: sociales, en donde entran los agentes de pastoral y misioneros, así como otros voluntarios que indirectamente forman parte de la Iglesia (feligresía), incluyendo la sociedad civil; los económicos, que se refieren a los organismos y empresas de la Iglesia, como colegios, imprentas, centros hospitalarios, entre otros, de los que se obtienen recursos para financiar proyectos pastorales y de otra índole, y la Iglesia en tanto autoridad de gobierno que puede pensarse desde el Vaticano como Estado, y en dimensiones más locales como las diócesis o las parroquias. 
y líderes de los pueblos indígenas y campesinos ya organizados, el papel del Gobierno federal mexicano o los gobiernos estatales, y los empresarios con sus fundaciones, entre otros.

Si se concentra esta temática en la cuestión ecológica, puede verse con claridad el rol de la sociedad organizada a favor del medio ambiente, los empresarios a través de fundaciones y organizaciones que apoyan económicamente y con otros bienes algunas iniciativas de la sociedad civil, así como el Estado que los respalda a través de la implementación de políticas públicas para que entre los tres actores, en una dinámica de diálogo, logren metas específicas para preservar los recursos naturales.

No obstante, sobre estas situaciones pueden verse escenarios mucho más complejos, en los que participan más actores con un carácter distinto y dimensiones locales y globales que explican la gobernanza o, mejor dicho, la nueva gobernanza. Al pensar en la Iglesia católica y en otras denominaciones religiosas en contextos rurales y urbanos en relación con el medio ambiente, se suman figuras eclesiásticas con papeles distintos: la Iglesia como gobierno eclesiástico, la Iglesia como actor económico a través de sus empresas (colegios, institutos, tiendas, fábricas, imprentas, entre otras) y la Iglesia mediante sus agentes de pastoral, misioneros y feligreses laicos que colaboran en organismos que apoyan y se organizan junto con la sociedad para obtener resultados específicos a favor del entorno natural.

Así, es posible concebir una acción pastoral y a la Iglesia católica como partes de un componente alternativo, incluso complementario, de la gobernanza, razón por la que podría pensarse en la acción pastoral en la gobernanza como una tendencia actual de praxis, aunque también inspirada en las bases de liberación 
hacia los menos favorecidos, como ya se ha planteado a lo largo del texto.

En este apartado enfocado en la cuestión del medio ambiente y la acción pastoral, debe destacarse que el actor principal de la sociedad civil es la población indígena. Su relación con los miembros de la Iglesia, conocidos como agentes de pastoral o misioneros, es sólo una fracción del escenario de gobernanza que se complementa con el papel del gobierno, sea chiapaneco, oaxaqueño, el Estado mexicano o guatemalteco. En este estudio de caso se trata del Gobierno federal y el gobierno estatal chiapaneco.

Al respecto, es importante señalar que en este tejido o esquema de relaciones influyen sobremanera preceptos ideológicos que vienen de tiempo atrás. Es indispensable hacer hincapié en que así se hable de gobernanza o se use otro término para explicar este sistema de apoyo y relación entre redes sociales (Iglesia, ONG, Estado, sociedad civil, empresa, entre otros), proviene de posturas ideológicas de décadas, incluso, siglos atrás. En la presente investigación se ha mencionado el liberacionismo de los años sesenta en adelante en América Latina que ha permeado en la labor pastoral, específicamente en Chiapas.

De las bases liberacionistas que se han transformado con el tiempo también surge la idea de autosostenibilidad y autosuficiencia, incluso de un escenario de gobernanza como parte del terreno de la acción pastoral, sea desde una perspectiva ecológica o de la lucha por la independencia de prácticas asistencialistas. Como se planteó al inicio de este libro, la preocupación por la cuestión de la tierra y de la Tierra viene de mediados del siglo $\mathrm{XX}$, ya había una visión ambientalista como uno de los elementos indispensables para pensar la liberación. Para comprender mejor 
esta aseveración es vital definir la ecología desde una óptica religiosa y cristiana, para lo cual Leonardo Boff es un referente, pues ya no es suficiente pensar en una pastoral de la tierra en el sentido de una lucha agraria, sino desde un enfoque más místico, es decir, la "ecología es relación, interacción y diálogo de todas las cosas existentes (vivientes o no) entre sí” (Boff, 2000, p. 19).

Por lo mismo que la ecología va más allá de lo meramente biológico y que al pensar en ecosistemas debe pensarse en una suerte de medio ambiente social, significa que el ser humano con todos los fenómenos políticos, sociales y culturales en relación con él forma parte de ese ecosistema, por lo tanto, la justicia social y la religiosidad integran este ecosistema también. Uno de los orígenes del problema ecológico es la idea antropocéntrica que, desde la perspectiva judeocristiana, califica al ser humano como superior y el que domina a la naturaleza, en lugar de que sea parte de ella. Es evidente que esta idea ha sido uno de los cambios que la Iglesia católica ha debido experimentar para pensar en una praxis pastoral a favor de lo ecológico y esto es congruente con lo que Boff define como relación, interacción y diálogo, lo que significa que está en la interacción y el diálogo la clave para resolver el complejo problema ambiental, y por ende, el problema de la pobreza y la marginación, es decir, para restablecer un equilibrio.

La Iglesia católica, desde una visión global, ha dado un interesante giro discursivo que se muestra en las palabras del papa Francisco, vertidas en la encíclica Laudato $\mathrm{Si}$, en la que también refiere a la ambición de un sistema económico en el que estamos inmersos y que se concentra más en la explotación, tanto de recursos naturales como humanos, en beneficio de unos cuantos 
y, por lo tanto, propicia el incremento de la huella ecológica y la pauperización del mundo. ${ }^{31}$

La ecoteología responde muy bien a esta coyuntura, que más que un concepto es una praxis pastoral. Acuñada por el teólogo Leonardo Boff, proviene desde las décadas de 1960 y 1970, generada a partir del Concilio Vaticano II, aunque con mayor énfasis se advierte el tema ecológico en la CELAM de Santo Domingo de 1992 y continuó en la de Aparecida de 2007 (Valentini, 2009).

Desde la pastoral de la Tierra de 1960 y 1970, la cuestión agraria entrañaba una preocupación por la cosmovisión y el ethos de los pueblos originarios que tenían en la tierra su Biblia. No es suficiente pensar en la dependencia de los pueblos hacia el agua y otros recursos naturales para sobrevivir, sino que estos elementos mismos son su forma de pensar y de manifestar su religiosidad. La Iglesia latinoamericana, desde esta época hasta el día de hoy, asume un compromiso con estos fines ecológico-sociales y con el propósito de liberar a los más afectados por estos impactos globales, que son los pobres.

En este tenor, hay un término muy adecuado para definir el referido complejo entramado ecológico social, que es la noción de

${ }^{31}$ Dice la encíclica Laudato Si": "Esta hermana [la Tierra] clama por el daño que le provocamos a causa del uso irresponsable y del abuso de los bienes que Dios ha puesto en ella. Hemos crecido pensando que éramos sus propietarios y dominadores, autorizados a expoliarla [...] olvidamos que nosotros mismos somos tierra (Francisco, 2015, p. 2). Asimismo, con lo que Francisco denomina la cultura del descarte se habla del beneficio de unos pocos no sólo con la explotación de la naturaleza, sino de las mejores condiciones ecológicas para vivir: “[...] se crean urbanizaciones «ecológicas» sólo al servicio de unos pocos, donde se procura evitar que otros entren a molestar una tranquilidad artificial. Suele encontrarse una ciudad bella y llena de espacios verdes bien cuidados en algunas áreas «seguras», pero no tanto en zonas menos visibles, donde viven los descartables de la sociedad" (Francisco, 2015, p. 45). 
ecologismo de los pobres, de Joan Martínez Alier, que, en esencia, consiste en una serie de "movimientos sociales de los pobres [que] a menudo tienen contenido ecológico, al intentar resguardar los recursos naturales fuera de la economía crematística mercantil bajo control comunitario" (Martínez Alier, 2009, párr. 18). De hecho, para este economista es claro el ecologismo de los pobres:

\begin{abstract}
Desde el punto de vista de los pobres, podemos interpretar el desarrollo del capitalismo (o del sistema de mercado generalizado) como una Raubwirtschaft o economía de rapiña continuada y creciente para impulsar la acumulación de capital y cubrir los gastos de los ricos. Entendidos así, los movimientos sociales de los pobres a menudo tienen un contenido ecológico (quizás sólo implícito), al intentar resguardar los recursos naturales fuera de la economía crematística, mercantil, bajo control comunitario (Martínez-Alier, 2009, párr. 18).
\end{abstract}

La lucha de los más desfavorecidos por acceder a los bienes ecológicos necesarios para una vida digna y para su supervivencia es el eje de muchos movimientos sociales por todo el mundo, cuyos militantes sin ser académicos ni conocedores de las consecuencias de la devastación ecológica contribuyen a su mejoramiento. Lo anterior constituye un tipo de ecosocialismo cada vez más extendido en varias comunidades y localidades de las llamadas economías emergentes. Así como desde la pastoral de la Tierra, empapada de las ideas liberacionistas del siglo XX, había una lucha agraria a la par de una conciencia semántica de la Tierra en tanto el lienzo en donde se observa la cosmovisión y religiosidad autóctona, también ha habido una continuidad teórica y 
práctica a favor del medio ambiente y del derecho de los pueblos originarios por acceder a los recursos naturales para su subsistencia, de ser así se contrapondría a la idea de liberación.

La ecoteología, y sobre todo el concepto de democracia cósmica de Boff, aborda el punto central del medio ambiente desde la Iglesia católica que asume a la naturaleza de América Latina como un ecosistema en sintonía con los pueblos originarios, excluyendo a los europeos y su intromisión a través de la guerra justa. Martínez-Alier, haciendo referencia al mencionado concepto de Boff, dice que en la actualidad el medioambientalismo apela a la religión y a lo sacro de la naturaleza. De hecho, Boff irá modificando esta noción de democracia cósmica por la de democracia ecológico-social, que critica la idea judeocristiana que asume al ser humano como dueño, rey y señor de la creación y el universo, en lugar de reconocer la alteridad de cada ser.

Así, la ecoteología no sólo consiste en la distribución equitativa de los recursos naturales, ni en una ecología indigenista, sino en reconocer a los pueblos indígenas y su vínculo con la Tierra y la naturaleza, en la que expresan su cosmovisión, su religiosidad y cultura, en una pastoral de la Tierra renovada en tanto alternativa de reeducación, interacción e impulso a fin de que se retome ese lazo entre el campesino indígena o no indígena con la naturaleza, para obtener su autosuficiencia (Valtierra Zamudio, 2015). La ecoteología parte de una serie de principios prácticos. Para empezar, no únicamente la Iglesia católica latinoamericana "de izquierda" se concentra en una conciencia étnica y en condenar la imposición de la fe por la vía histórica de una conquista o guerra justa, sino que se agrega la cuestión ecológica como una forma de asesinato de la cultura, es decir, la devastación ecológica es una 
devastación cultural, al igual que provocar la dependencia de los indígenas hacia productos procesados y usos y modas urbanas.

La pastoral indígena renovada sintetiza la práctica liberacionista, el reconocimiento a la diferencia étnica y religiosa, así como la interacción, según se define esta ecoteología. En esencia, son tres líneas las que se siguen para realizar tal praxis:

1. La comunicación, como vía a través de la que se puede llevar a la práctica ese mensaje dialógico e intercultural a partir de la interpretación del mensaje del Concilio Vaticano II.

2. La teología india cristiana como una acción de vernaculización de la Iglesia católica en donde pueden converger y dialogar todas las culturas con sus especificaciones y rasgos culturales y religiosos.

3. El buen vivir como un concepto indígena que define una forma de existir en relación con el entorno natural, en la que se hace uso de la naturaleza para mejorar la calidad de vida de los seres humanos; por ejemplo, la herbolaria o la medicina tradicional, incluyendo la meta de llevar un ciclo vital autosostenible.

La Iglesia católica ha buscado en la ecoteología una misión que, más que adoctrinamiento, promueva una educación integral, de acompañamiento a las comunidades y luchar con sus habitantes -no en representación de ellos-- por su liberación, al propiciar el abandono de la dependencia hacia programas asistencialistas y sustituirlo por la autosostenibilidad y la autosuficiencia.

Cierto es que la ecoteología se concentra más en la educación integral, en el buen vivir y en la cultura de la prevención 
en materia ecológica y de salud. Sin embargo, es indispensable considerar la religiosidad autóctona y la epistemología indígena para llevar a cabo un proceso que no sea invasivo e impuesto. Para ello, además de crear entornos y prácticas sostenibles, no se deja de lado el análisis de la realidad y la crítica tan característicos de la teología de la liberación, esto es, "sitios de reflexión autónoma de lucha de los cristianos por la liberación" (Caravias \& Barros, 1990, p. 57). Así pues, se debe hablar de una ecoteología en la praxis pastoral, en primer lugar, como un acompañamiento y orientación del individuo subalterno hacia su liberación desde él mismo, su posición y realidad, así como el respeto y reconocimiento de su etnicidad, cultura y religión; y, en segundo lugar, desde una perspectiva crítica y de lucha por la dignidad humana, a través de la lucha por la Tierra.

Existen muchos ejemplos de ecoteología. A continuación, se abordará uno de ellos que se ubica en el estado de Chiapas, además de mencionar la actividad ecoteológica y liberadora en el estado de Oaxaca.

Educación, revolución y ecología desde la Iglesia católica en el sur de México

En la pastoral indígena la ecología es de vital importancia por ser el entorno del que dependen los pueblos indígenas y con el que se relacionan no sólo para obtener los recursos que extraen para sobrevivir, sino por representar su cosmovisión y su fe. Existe una tendencia desde afuera de interpretar la religiosidad de dichos pueblos a partir de la ecología, lo que en parte se advierte en la perspectiva que se tiene del buen vivir 
o de conceptos complejos como la Pachamama; pero es cierto que en la cosmovisión indígena la ecología conlleva muchos elementos simbólicos en los que se observa la numinosidad y las prácticas religiosas de comunidades que son cristianas, pero que mantienen rasgos prehispánicos.

La ecoteología sostiene y reconoce estas características en los pueblos indígenas y campesinos, y busca comprender la Tierra desde el quehacer teológico, para la puesta en marcha de prácticas pastorales en defensa de ella, ya no en su acepción agraria como tal, sino global, es decir, la defensa del planeta, de los recursos naturales cuyo agotamiento además de afectar a los pueblos indígenas, también impacta en el mundo entero. Es evidente que la ecoteología no siempre fue así, sino que es parte de la evolución ideológica que el tiempo y las circunstancias han propiciado.

La inspiración ecoteológica se encuentra en América Latina en muchas diócesis; la de Limón en Costa Rica, la de la Verapaz en Guatemala, la de Riobamba en Ecuador o la de Bogotá en Colombia son ejemplos de un ámbito latinoamericano en que la amenaza al medio ambiente es constante y que ha habido también una presión y conciencia sobre esta situación en la sociedad civil, al grado de implementar políticas verdes.

$\mathrm{Al}$ respecto, destaca Ecuador con el proceso de constitucionalización del ambiente, en 2008, que reconoce la diversidad espiritual de los pueblos indígenas y su propósito de convivir con la diversidad y en armonía con el entorno natural para lograr lo que se denomina en kichwa el sumak kawsay o buen vivir (Murad, Mahecha \& Londoño, 2016). Costa Rica ha hecho lo propio, más allá de la labor eclesiástica, al impulsar propuestas ambientales 
que han dado resultados visibles como en materia energética, de la que 98\% es eólica y renovable (Gobierno de Costa Rica, 2018).

En esta preocupación medioambiental que trasciende lo meramente religioso, la Iglesia -mediante la ecoteología- se ha concentrado en regiones y zonas de devastación que se relacionan de manera muy directa con la marginación reproducida, no sólo por las condiciones étnicas y físicas, sino también por estructuras y políticas de corte asistencialista que generan una dependencia a los programas sociales. En gran medida, la acción ecoteológica se enfoca en contextos en los que las políticas gubernamentales no resuelven problemas de fondo de tipo ecológico en el sentido social, cultural y medioambiental, y se emprenden proyectos en conjunto y en diálogo con la comunidad, en los que acompañan, asesoran y/o educan, pero buscan que las sociedades con las que colaboran sean autosuficientes.

El Estado mexicano, a pesar de tener una economía más grande que la de los casos mencionados dos párrafos atrás, mantiene una política asistencialista que no atiende las necesidades más apremiantes de los pueblos indígenas, incluyendo la cuestión ecológica. Es aquí donde organizaciones no gubernamentales y la acción pastoral han contribuido. El caso de Chiapas es ejemplar. En la diócesis de San Cristóbal de Las Casas se pueden encontrar iniciativas ya de tiempo atrás con bases ecoteológicas. La Misión jesuita de Bachajón, por ejemplo, encabeza con los pueblos tseltales un movimiento de nombre Modevite, que significa Movimiento de Defensa de la Vida y el Territorio, que incita a la independencia en una suerte de gobierno comunitario que defiende sus tierras de los grupos de poder que "quieren apropiarse no solamente del territorio, sino también de la sangre 
de la misma madre, de sus recursos como son los minerales, como es el agua, como es el petróleo" (Iglesias y Minería, 2017, párr. 8 ).

Esta misión con perspectiva liberacionista concentra sus esfuerzos en la defensa de la tierra, pero también reconoce el significado de ésta para los pueblos indígenas, reconoce que la "tierra y el territorio son más que trabajo y alimento: son también cultura, comunidad, historia, ancestros, sueños, futuro, vida y madre" (Modevite, 2016, s/p).

El caso de la Misión de Guadalupe de los Hermanos Maristas con la participación de otras organizaciones como Enlace, A.C., encauza su acción pastoral en distintas áreas, de las que destaca la educación, en donde se pone especial atención en la ecología, sea para diseñar dispositivos amigables con el medio ambiente y de bajo costo que contribuyen al mejoramiento de las condiciones de vida de las comunidades campesinas de la zona sureste de Chiapas, o para colaborar en los procesos educativos con una perspectiva ecológica que ha dado frutos con la creación de una universidad alternativa conocida como Universidad de la Montaña (Unimon). El caso de esta universidad es muy interesante en términos de gobernanza, pues no es el organismo eclesiástico ni el gobierno quienes la promueven y sostienen, sino la población de comunidades que sin adherirse al EZLN, ni depender de organismos gubernamentales como la Secretaría de Economía, la Secretaría de Educación Pública o la de Desarrollo Social, han entablado un diálogo con los misioneros y ONG para diseñar una propuesta de educación integral que vea por los intereses y necesidades de la región. La Unimon es una iniciativa de pueblos de origen tojolabal y campesinos que han pedido apoyo a la Misión de Guadalupe para la educación e instrucción en el 
aspecto cultural y ecológico; se concentra, sobre todo, en la creación de estrategias ecológicas que ayuden a mejorar la situación de marginación de las comunidades campesinas en el sureste del estado de Chiapas, lo que se relaciona con otros graves problemas que se viven en estas regiones, como la salud, la devastación del entorno y la pobreza material.

La Unimon comenzó con un programa más tradicional de educación y con modelos similares a los cursos de catequistas, en los que se enseñaban, además de la palabra de Dios, oficios como carpintería y talabartería, entre otros. Empezó impartiendo cursos de "leer y contar", cursos de "cultura e historia", pero también se fue integrando la enseñanza e instrucción de crear una tecnología agroecológica que no sólo no dañara al medio ambiente, sino tampoco a la salud con el uso de insecticidas y fertilizantes naturales. Después se avanzó un paso más al formar maestros y promotores ecológicos, así como de salud. Los resultados de esta educación distinta fueron inmediatos y muy interesantes. De entrada, la situación ecológica del entorno de las comunidades empezó a transformarse con la siembra de árboles de rápido crecimiento que daban leña y que frenaban la desforestación tan grave en la zona; se construyeron cada vez más letrinas secas a fin de aprovechar la materia para hacer compostas, así como estufas ahorradoras de leña y potabilizadores de agua.

Es claro que en estas comunidades no sólo había un ahorro de recursos y beneficios ecológicos, sino que la misma gente aprendía a realizar estas actividades, crear esta tecnología y promoverla. Los resultados daban cuenta de un desarrollo sostenible y de autosuficiencia. Entre los aspectos que deben destacarse en proyectos de este tipo es que se efectúan a partir de una 
relación que no depende de un movimiento guerrillero revolucionario, de un programa de gobierno o una iniciativa de una transnacional, sino de la comunidad misma, es decir, de la sociedad organizada que se explica en la definición de sociedad civil de Hernández Legorreta, arriba expuesta.

Las sociedades de voluntarios que pertenecen a la ONG ENLACE, A.C. y los colaboradores laicos (incluso no religiosos) de la Misión de Guadalupe para fundar un departamento de educación y uno de creación de tecnología ecológica y sostenible es prueba del acuerdo entre estas agrupaciones diversas que mantienen, al cabo, un diálogo con otras instancias como la Iglesia católica. Las mecánicas que se generan entre instancias de distinta naturaleza son, en esencia, una forma de nueva gobernanza, pues a pesar de los discursos autonómicos que se escuchan en el contexto, no sólo hay una lucha por el reconocimiento a la diferencia étnica y a la autosuficiencia de estas comunidades por parte de otras entidades, incluyendo las gubernamentales, sino una lucha por la no intervención, por ejemplo, de las transnacionales con la finalidad de impedir la explotación de los recursos naturales a los que tienen derecho estos individuos o exigir al Estado el respeto a sus derechos humanos, ante las evidentes violaciones que se viven en estas localidades no sólo por el arrebato de sus recursos naturales o el escaso acceso a salud (y de calidad), sino por acciones aún vigentes como la expulsión de muchos individuos de sus propias comunidades por parte de otros habitantes que se han convertido a otra religión o que tienen otros intereses políticos, y se demanda la intervención de la justicia para resolver estos escollos.

La ecoteología como una forma de liberación, revolución y contienda por el planeta Tierra está vinculada con la educación, 
pero también con la militancia. Es muy claro que sus bases en la teología de la liberación entrañan una vocación revolucionaria y militante a través de una educación ecológica, una conciencia de la desigualdad que genera la devastación ambiental en términos de escasa e injusta distribución de recursos, la mirada de la sociedad como parte de un ecosistema y que la tierra es la esencia del pensamiento y cosmovisión de los pueblos.

Cuando se habla de gobernanza, uno de los actores principales a considerar es el Estado. Si bien con los principios de la teología de la liberación se ha buscado una posición antagónica a un Estado que representa un sistema económico y político que afecta a la subalternidad, actualmente con la acción pastoral y la ecología misma es claro que se ha buscado una suerte de acercamiento y diálogo con el gobierno, como se ha mencionado, con el propósito de reconocer la diferencia y la autosuficiencia de los pueblos indígenas y campesinos. La militancia de diversos grupos de la sociedad civil que tratan de proteger los derechos identitarios, pero también sus recursos y acceso a ellos, gana cada vez más terreno.

En el estado de Oaxaca, Arturo Lona Reyes, obispo emérito de Tehuantepec, es un fiel ejemplo de activismo con los pueblos indígenas de la región, pero también de intentos por dialogar con el Estado para que responda y proteja el ecosistema de Oaxaca que sufre una devastación cada vez mayor por la tala inmoderada, por lo que "es necesario mantener viva la defensa de los pueblos, y que sea bien distribuida para todas y todos, porque la triste realidad es que no hay trabajos dignos y con buenas condiciones laborales" (Manzo, 2017, párr. 9).

Las palabras de Lona Reyes se refieren a la dependencia de las comunidades indígenas hacia su entorno natural y la razón 
por la que debe lucharse para salvaguardarlo. Por esta razón, en el discurso dado en agosto de 2017 en Juchitán de Zaragoza, insta al gobernador del estado oaxaqueño, Alejandro Murat, a trabajar por impulsar una política "más madura" hacia la autonomía de estos pueblos y su labor de años con la fundación de bachilleratos maristas y un par de cooperativas de producción de café y ajonjolí que han mejorado las condiciones de vida de los pobladores (Manzo, 2017) comprueba la apuesta de una pastoral que no se enfoca en la liberación de los pobres y los oprimidos a través de una organización antagónica respecto del Estado, sino que busca alcanzar el equilibrio y el diálogo en un escenario más horizontal y en el que se haga escuchar la voz, independencia y necesidades de los indígenas para tener una vida digna.

La zona del Istmo es sumamente conflictiva también por cuestiones de posesión de la tierra y por el deterioro ecológico que hace que los habitantes lleven una vida precaria. De nuevo, la decisión de mucho tiempo atrás de defender la tierra y los derechos de las personas, así como un par de recursos indispensables como la sostenibilidad a través de la cooperativa de producción de café y ajonjolí, y la educación que impulsó Lona Reyes mediante los bachilleratos en los que la presencia marista se observa hasta el día de hoy, es una prueba de no buscar un cambio a través de aislarse, sino de relacionarse con el mundo, de dialogar con otras instancias y actores, entre ellos el Estado, pero también de proporcionar herramientas para que los pueblos indígenas sean independientes.

El papel de la educación en este proyecto de vida de Lona Reyes es brindar la formación suficiente para ser crítico y tener instrumentos para valerse por sí solos, comprender los problemas 
y sus causas, y tener los recursos y argumentos suficientes para defender sus derechos. La creación de sociedades cooperativas, por otro lado, ofrece a los pobladores una vía de empleo digno y equitativo, además de la oportunidad de vincularse y articularse con el mundo al exportar sus productos, en este caso, café orgánico.

Si bien la figura de líderes como Lona Reyes, Ruiz García en su momento en Chiapas, los agentes de pastoral en general, así como de los voluntarios en alguna ONG, es un motor importante para el impulso de proyectos de liberación y sostenibilidad, también es un hecho que la iniciativa y trabajo de la sociedad civil - en este caso de los pobladores de las distintas comunidades indígenas y campesinas en el país - está presente y ha contribuido en las últimas décadas al establecimiento de una plática con actores como el Estado y empresarios. Es interesante observar cómo proyectos, por ejemplo el transístmico para comunicar el Atlántico con el Pacífico por parte de la administración del actual presidente de la República mexicana, Andrés Manuel López Obrador, engloba temas que se relacionan con el mejoramiento de la vida de los habitantes de la zona, la protección del entorno ecológico, pero también un diálogo entre él como representante del gobierno, la población y otros actores como el propio Arturo Lona Reyes, con quien se reunió el 26 de febrero de 2019 para conversar al respecto (Zavala \& Morales, 2019).

Cuando se habla de diálogo en estos contextos, es importante considerar la cuestión de la comunicación intercultural como un elemento también indispensable en el marco de la gobernanza. En otros espacios, al realizar una investigación sobre la pastoral indígena en la década del 2000 al 2010, se había propuesto la idea de una pastoral de la interculturalidad, en donde el factor 
comunicativo y el desarrollo de la alteridad era indispensable. Sin embargo, una pregunta que surge después del desarrollo y comprensión de lo que implica la ecoteología, los cambios políticos que por lo menos América Latina, y en especial México, vive, así como la acción cada vez más visible de la sociedad civil, es si podría hablarse de una acción pastoral en la gobernanza. De esto se tratará el siguiente apartado que cerrará este tercer y último capítulo.

\section{La comunicación intercultural en el proyecto de la pastoral indígena}

La gobernanza en relación con lo sociorreligioso, como se ha ido desarrollando a lo largo de este capítulo, implica aventurarse a caracterizar una labor como la pastoral indígena en la que si bien puede ubicarse un origen colonial (y colonizador), consiste en una serie de acciones que han buscado a lo largo de la segunda mitad del siglo XX transformar esas lógicas en pos del reconocimiento de la diversidad étnica y discernir la cultura del otro.

La pastoral está ceñida por el precepto de acompañar al rebaño, en tanto metáfora de la otredad, y con base en el mensaje paulino de "hacerse todo para todos para ganarlos a todos para Cristo". ${ }^{32}$ De la misma manera, en un intento de

\footnotetext{
32 En la primera epístola a los corintios, san Pablo alude a una forma de adaptación que coincide con la idea de encarnación o inculturación. Esto es claro cuando dice: "A los débiles me hice débil, para ganar a los débiles; a todos me he hecho todo, para que por todos los medios salve a algunos. Y todo lo hago por amor del Evangelio, para ser partícipe de él (Biblia Latinoamericana, 2005, la Cor. 9:22-23).
} 
"hacerse indígena para los indígenas", esta pastoral cobra sentido junto con la noción de Iglesia autóctona y de inculturación. La etnografía realizada, por ejemplo, en el estado de Chiapas y en Guatemala acerca de la teología india cristiana corrobora esta posición. Pero si se habla de liberación, de la militancia de religiosos y laicos en las misiones y en la acción pastoral o de ecoteología, del involucramiento en asuntos distintos de la "catequización" de las comunidades, entonces la pastoral indígena se convierte en un discurso que sostiene una tarea de lucha y defensa de los derechos ecológicos, derechos humanos, derechos sociales, derechos culturales; es decir, los derechos fundamentales de los pueblos indígenas.

$\mathrm{Al}$ parecer, el término pastoral indígena ha transformado su significado y su praxis, por lo menos en apariencia. Se trata de un conjunto de acciones con una postura más crítica y actualizada, un tipo de aggiornamento que no se preocupa por combatir al "protestante", antes bien es incluido para enfrentar juntos la injusticia y liberar al oprimido, y que no se ocupa primordialmente de catequizar, sino de apoyar en otros procesos que generen bienestar a las comunidades indígenas. Esto significa que el objetivo no es ya encontrar enemigos y liberarse contraponiéndose de forma radical y violenta, sino liberar a través del diálogo y acciones que fomenten una independencia de los mecanismos de consumo que atentan contra los ideales de sostenibilidad en el aspecto ambiental, económico, organizativo, político, etcétera.

Empero, en este propósito de diálogo existe una gran complejidad. Pensar en la gobernanza como una alternativa frente a un Estado en crisis y una situación mundial global que 
se ha caracterizado por ampliar la distancia entre ricos y pobres ${ }^{33}$ implica resolver el problema de la comunicación. En este sentido, la comunicación como clave para emprender soluciones conlleva el intercambio de códigos que varían de nación en nación. Es evidente que, desde una perspectiva global, esto se pretende solucionar con el uso de una lengua universal como el inglés, con lo que no se establece necesariamente una comunicación cabal, pues se ignoran los elementos culturales, la forma de ver la vida, la religiosidad, las necesidades de una comunidad que dependen de su entorno, sus creencias y su cosmovisión. Esto mismo ocurre, desde una óptica microsocial, al interior de una nación.

En el contexto de estos espacios locales o microsociales se ha tratado de manejar la idea central de una pastoral indígena propositiva en una dinámica de gobernanza más horizontal, de diálogo, militancia y de generar escenarios que se alejen de la representación o de "hablar por el otro" y más de llegar a acuerdos de acciones y exigencias en busca de una mejor vida y de dignidad. Pero ¿cómo lograrlo sin un adecuado análisis de la realidad y sin una buena comunicación, sobre todo, intercultural? En las sociedades actuales, gran parte de los problemas de incomunicación (miscommunication) obedece a la diferencia generacional, de género o del contexto mismo; se habla de individuos que probablemente hablan la misma lengua, pero al provenir de contextos diferentes o tener ideologías distintas surgen inconvenientes de comunicación.

\footnotetext{
33 Bourguignon (2017, p. 29) advierte que la desigualdad global "presenta una combinación bastante compleja de la desigualdad entre las naciones y de la desigualdad dentro de las naciones".
} 
Estas diferencias ideológicas y de estructuras socioculturales en una misma sociedad han sido objeto de análisis por parte de académicos como Deborah Tannen (1986), en una búsqueda de evitar problemas que derivan de la incomunicación, como los divorcios, fracasos en negociaciones de tipo mercantil, impedir conflictos que pueden ser de gran dimensión como una guerra por desavenencias de fe o malentendidos. Esto es real y la historia respalda este argumento y, en el fondo, son situaciones que en principio se suscitan por diferentes estilos conversacionales para expresar determinados significados.

En entornos indígenas el acto comunicativo se complica, pues desde una posición urbana como la de los agentes de pastoral, de los activistas o del propio antropólogo social que investiga un grupo social determinado, hay de entrada desconocimiento de los códigos y valores sociales propios de la comunidad. En la comunicación entre dos grupos étnicos, como es el caso de un conjunto de agentes de pastoral y uno indígena, el proceso comunicativo está determinado por las diferencias culturales, y muchas de ellas conducen a una "confrontación" o encuentro de reglas o máximas comunicativas distintas entre uno y otro, alimentadas por fenómenos socioculturales muy comunes en estas relaciones de alteridades como la inferencia, el grado de cooperación comunicativa entre los participantes, los estereotipos, además de otros aspectos.

Los problemas de comunicación en contextos interculturales como los que representan los agentes de pastoral católicos y los pueblos indígenas llevan a analizar desde una visión teórica dos ejes: el primero en relación con la interculturalidad y la díada identidad-alteridad, y el segundo es la comunicación intercultural. 
Lo anterior demanda adentrarse a los estudios culturales y de la interculturalidad, por un lado, y los estudios del lenguaje, por el otro. A continuación se desarrollarán estos dos aspectos.

\section{Interculturalidad, identidad y alteridad}

A partir de los años ochenta y hasta el día de hoy, la interculturalidad es un reto en los escenarios en los que se pretende establecer una comunicación exitosa. El problema de la comunicación radica no sólo en el nivel de léxico, sino en el cultural e identitario. En este sentido, es pertinente hablar de interculturalidad, entendida de forma general como una vía para responder a las reivindicaciones de todos aquellos grupos sociales, como los pueblos indígenas, que se encuentran en una situación concebida como vulnerable o desfavorable frente a otros grupos, y que además han sido explotados, invisibilizados y marginados.

Es evidente que hay muchas interpretaciones de interculturalidad, como la de Raúl Fornet-Betancourt, que la define como un proceso polifónico; es decir, un diálogo abierto a opiniones y perspectivas de las otras culturas desde donde se contrastan las propuestas (Fornet-Betancourt, 2001), a partir de las cuales se sostiene un diálogo cultural que no se constriñe a un paradigma determinado, lo que rompe con un etnocentrismo y lleva un proceso de descentrar. Así, dice Fornet-Betancourt, se requiere "superar la actitud practicada hasta ahora, tanto por la filosofia como por las ciencias sociales, de ver al otro como un objeto de conocimiento y no como un sujeto de un pensamiento propio pensante" (Fornet-Betancourt, 2001, p. 37). 
A propósito de la alteridad, existen muchas perspectivas disciplinares e interpretaciones acerca de qué es y cómo surge. En el caso de América Latina, el clásico ejemplo para hablar al respecto es el de la llegada de los europeos al "Nuevo Mundo" y con ello el famoso "encuentro de dos culturas", que produjo un cambio sustancial y muy profundo, empezando por la transformación cultural (Gruzinski, 2007). Esta transformación a la que alude Gruzinski sucedió a lo largo de mucho tiempo de forma paulatina y en ese lapso, lo que se experimentaba durante el contacto entre diferentes culturas era la sensación de extrañeza al observar recíprocamente los rasgos físicos, las características culturales tan distintas unas de otras, la lengua, etcétera, que dio pie a una serie de juicios y categorías que levantaban fronteras culturales muy precisas para diferenciarse, pero también en esa diferenciación había elementos que se fusionaron o sintetizaron, lo que se ve con claridad en la gastronomía, la lengua y, sobre todo, en la religión.

Sin embargo, a pesar de esto no puede pensarse que había un contexto de interculturalidad. El indígena ha sido visto durante siglos como alteridad que, en México, se distingue por una imagen uniforme de individuos sin educación, pobres materialmente, desaseados y como un peso que debe cargar la nación. Por ello, la importancia de las Ciencias Sociales con representantes como Guillermo Bonfil Batalla durante la segunda mitad del siglo XX, pues se empieza a luchar por que el indígena sea reconocido, que seamos conscientes de sus diferencias culturales y, por lo tanto, modificar las políticas culturales que no respetan en la práctica esta diversidad (Bonfil, 2005). La manera de lograrlo 
es, precisamente, pensando al indígena (al otro) de forma distinta, como advierte Fornet-Betancourt.

La noción de otredad alude a un sujeto o un grupo social determinado con un origen y cultura distintos a lo propio. Stephen Harold Riggins hace una división entre el otro social, que se refiere a "toda la gente que el yo [self] percibe como radicalmente diferente", y el otro moderno que remite a una perspectiva bajtiniana que tiene que ver con "el subconsciente, una fase del yo o la experiencia del autoextrañamiento" (Riggins, 1997, pp. 3 y 4).

El otro social es el que aparece en la literatura decimonónica y de principios del siglo XX como el salvaje, el nativo y otros términos más bien peyorativos, y que no se diferencian tanto de la noción y objetivos que se usan el día de hoy. Sólo que en la actualidad se utilizan eufemismos para llamar a los indígenas como grupos originarios que se distinguen del resto de los habitantes de la nación mexicana ya sea por las características físicas, el grado de civilidad, la lengua y la manera en que ésta se usa en lo cotidiano, entre otros aspectos.

Otra forma de diferenciarse entre grupos sociales o étnicos es a través de una suerte de discriminación que Todorov (1989) denomina exotismo primitivista. Esta noción es muy próxima al "buen salvaje" y no necesariamente margina, pero sí excluye; es decir, consiste en una discriminación y esencialismo que idealiza al otro, pero que también (re)interpreta y habla por el otro, por lo que hay una forma de exclusión. La alteridad, por otro lado, requiere de un espacio de interacción con el yo. Es en éste donde "solamente la confrontación con las particularidades hasta entonces desconocidas de otros seres humanos -idioma, costumbres cotidianas, 
fiestas, ceremonias religiosas o cualquier otra cosa- proporciona la verdadera experiencia de la extrañeza" (Krotz, 2002, p. 57).

Con el concepto de otro social de Riggins y la explicación de Krotz se asume que el fenómeno de la alteridad u otredad está presente durante la interacción social, pero en el que la extrañeza también se experimenta y a partir de ella se categoriza y define el escenario y los actores que tratan de interactuar. El problema es que en este intento de interactuar y vivir la extrañeza hay una forma de ignorancia que impide intercambiar y decodificar los significados del otro, pues, desde la perspectiva de Wittgenstein, no somos capaces de imaginar la forma de vida del otro ni se ha pasado por un proceso de aprendizaje del lenguaje y cultura del extraño (Wittgenstein, 2004).

Para Wittgenstein, al igual que para Krotz, experimentar la extrañeza es toral en el camino de definir la otredad. Al respecto, Witold Jacorzynski -basado en Wittgenstein- dice que el otro es el que hace actividades extrañas y participa en formas de vida distintas, lo que implica que no entendamos a aquellos que no siguen "nuestras" reglas sociales y culturales. Pero en el caso de quienes sí siguen algunas de nuestras reglas, los podemos entender, aunque ya estamos influidos por el sentimiento de rareza que se enfoca en otras características racistas, neorracistas, políticas, ideológicas, etcétera, que impide entender al otro y reencontrarse con él (Jacorzynski, 2008).

De este último punto se extraen reflexiones muy interesantes en torno al fenómeno. En primer lugar, que la otredad se construye, se califica y define desde una posición central (etnocentrismo), tanto en la teoría como en la praxis; a partir de esto se generan actitudes y categorías que inducen a la marginación 
y la exclusión, como los estereotipos. Por otro lado, y desde la perspectiva de la Iglesia católica y la pastoral indígena, lo que se intenta es romper con esta diferenciación, similar a lo que expone Bajtín:

Cuando nos estamos mirando, dos mundos diferentes se reflejan en nuestras pupilas. Para reducir al mínimo esta diferencia de horizontes, se puede adoptar por una postura más adecuada, pero para eliminar la diferencia es necesario que los dos se fundan en uno, que se vuelvan una misma persona (Bajtín, 2003, p. 29). ${ }^{34}$

Por último, la finalidad de comprender la alteridad, más allá de acortar las distancias entre el yo y el otro, es lograr un entendimiento equiparable al entendimiento lingüistico de Habermas. Este filósofo postula que en la interacción, en la acción comunicativa, dicho entendimiento lingüístico es crucial, ya que es lo que remite a un acuerdo racionalmente motivado alcanzado entre los participantes que se mide por pretensiones de validez, y al lenguaje, no sólo la lengua, sino al medio de interacción con que hablantes y oyentes se refieren simultáneamente a algo en el mundo objetivo, en el mundo social y en el mundo subjetivo que no sólo es el propio, sino el de los otros, para negociar

\footnotetext{
34 En esta cita de Bajtín destacan dos elementos: primero, no se habla de la fundición de dos personas en una, como se expone en el ideal cristiano tradicional, sino el discernimiento mutuo a través de la exotopía, como se anhela en la pastoral indígena; segundo, en la interacción en contextos interculturales intervienen procesos múltiples para definir la identidad y la alteridad a su vez, para comprender que un individuo no define su imagen y la del otro, sino a partir de cómo el otro se define también. Es decir, no se trata de un proceso único del yo definiendo al otro, sino que el otro también realiza un proceso de definición de nuestra persona, pues al final, el yo para el otro es una alteridad.
} 
definiciones de la situación que pudieran ser compartidas por todos (Habermas, 2014).

Esto último demanda entender la acción comunicativa que será objeto del siguiente apartado, pero también en ese proceso interviene la otredad y su importancia en el anhelo de establecer un diálogo intercultural. Para ello, la experimentación de la extrañeza y el entendimiento lingüístico - que conlleva la imagen, prácticas culturales, rituales, costumbres, significados que la otredad da a los acontecimientos, objetos y otros elementos- es, en síntesis, necesaria para una transformación de la perspectiva y mirada que se tiene hacia el otro, es decir, pensarlo diferente.

En ese tenor, la pastoral indígena ha buscado incesantemente pensar diferente al indígena por medio de la evangelización. El problema es que el propósito de su misión se sostenía aún en mecanismos coloniales, los cuales han sido severamente criticados en espacios académicos a lo largo de la segunda mitad del siglo XX. Hasta el momento, y ante este panorama, queda clara la importancia de comprender la alteridad u otredad, pero existe un aspecto más que es vital discernir, quizá a costa de esto último, y es la identidad. Sólo a partir de identificar y definir las dos partes que conforman el escenario de diálogo intercultural (por lo tanto, la interculturalidad per se) es como se puede corregir una mirada miope y parcial que desde la pastoral indígena y otros contextos y prácticas no religiosas han intentado superar progresivamente.

Lo primero que se requiere es aceptar la diversidad cultural que hay en un escenario de diálogo, situación que Deborah Tannen (1986) ya había advertido al referirse a diferencias culturales por género o por generación, pero, además, está el problema de la etnicidad con la cosmovisión, religiosidad y entorno que los 
determina como unos y no como otros, aunado a qué posición tiene el yo en esto.

Para analizar la interculturalidad, una estrategia es concentrarse en el escenario y los actores personificados como el yo/otro, es decir, la identidad/alteridad. Del segundo ya se ha abordado y justificado la importancia de comprenderlo, pero hace falta concentrarse en el yo, esto es, en la identidad. Sin embargo, no es tarea fácil, pues no se trata de actores o elementos del escenario que sean estáticos; tanto la alteridad como la identidad están en continua transformación.

En estudios de la identidad y la cultura, las aportaciones del sociólogo Stuart Hall (2010) son muy valiosas. Para este teórico jamaicano, cuando el sujeto social actual se presenta ante el otro encuentra a un individuo con una identidad determinada, pero también se "encuentra ante identidades [del otro] libremente flotantes, ante una pluralidad y fragmentariedad tal que dificilmente puede constituirse como una unidad o una totalidad" (Restrepo, 2014, p. 98). Es decir, el sujeto no tiene una identidad fija, pues depende de la situación histórico-política, de la ideología, por lo que está en continua transformación, de lo contrario el estatismo identitario implicaría algo similar a lo que Hobsbawm y Ranger (1993) definen como identidad inventada. En el caso latinoamericano, la identidad se ha definido desde una perspectiva europea y se diferencia de lo exótico, lo salvaje, lo indígena (otredad). Son estos "nativos" quienes no forman parte de la sociedad homogénea que conforma una nación, por lo tanto, pertenecen a un grupo de pobladores que aún no pueden considerarse civilizados. 
Cierto es que durante la segunda mitad del siglo XX esta óptica, por lo menos discursiva, ha ido cambiando. Se reconoce la diversidad (alteridad) de los pueblos indígenas, se reconocen sus lenguas, se lucha para que no sean calificadas de manera peyorativa como "dialectos" y se busca establecer una relación dialógica entre el yo y el otro, lo que implica una disposición utópica de pensarse recíprocamente de forma distinta, tratando de romper con estereotipos y no hablar por el otro o representarlo como si fuera un menor de edad.

Hasta el momento, y en este caso, la referencia del yo o la identidad alude al no indígena. Si se considera que el agente de pastoral es el yo y que es un promotor del diálogo intercultural, el primer aspecto que se trata en las juntas de pastoral y su labor es impedir, en la mejor de las situaciones, el llamado cierre étnico que propicia una diferenciación entre el yo y el otro. También es claro que en ambos la pastoral se concentra más en una acción de tipo social o de resolución de problemas en este rubro, como una forma congruente de llevar el mensaje cristiano y no sólo de catequizar. El problema se enfoca, además de ir pensando al otro de manera distinta y definir la identidad, en cómo lograr una comunicación efectiva, esto es, cómo establecer una comunicación intercultural.

\section{Comunicación intercultural}

En la actualidad, los contextos en los que diferentes culturas convergen son apreciados por distintas disciplinas científicas, algunas áreas de la Iglesia católica y organismos, tanto gubernamentales como no gubernamentales, con objetivos varios que 
van desde el registro y documentación de esta diversidad con fines estadísticos, hasta el emprendimiento de acciones no sólo en busca de la preservación de la diversidad cultural, sino en la mejora de las comunidades para contrarrestar la exclusión, la representación, la discriminación y, sobre todo, la desigualdad generada por un sistema económico, cultural y político que beneficia a unos más que a otros.

La manera en la que se pueden comprender con mayor profundidad estos fenómenos, es decir, los contextos y particularidades de muchos grupos sociales en una situación desfavorable, es a través de campos específicos que se concentren en la interculturalidad, en su análisis y en establecer un diálogo continuo para impedir caer en la reinterpretación de esas realidades. En lo que respecta a las Ciencias Sociales, en especial de las Ciencias de la Comunicación y los estudios del lenguaje, destaca la aportación de Ron y Suzanne Scollon (2001) cuando de comprender la interacción en contextos interculturales se trata; pero deben subrayarse las reflexiones, anteriores a estos teóricos, de un sociólogo muy vinculado a la fenomenología: Alfred Schütz.

Este investigador vienés hizo estudios con base en la fenomenología sobre la interacción y en su trabajo resalta la denominada intersubjetividad, que podría explicarse como un mundo en el que prevalece el sentido común, pues "vivimos en él como hombres entre otros hombres, con quienes nos vinculan influencias y labores comunes, comprendiendo a los demás y siendo comprendidos por ellos" (Schütz, 1995, p. 41). Se trata, pues, de un intercambio de significados y un proceso de resignificación de tales significados que se han intercambiado, lo que genera un mundo policéntrico en donde la intersubjetividad o la interacción 
no se establece por una de las partes, sino desde una visión más horizontal de significados comunes.

La intersubjetividad y el mundo en el que actúa, según Schütz, conllevan una mecánica de intercambio de conocimiento que se socializa a partir de tres premisas: el origen social del conocimiento, la reciprocidad de perspectivas y la distribución del conocimiento. En el caso de la reciprocidad de perspectivas, es claro que se refiere a dos entes que comparten el conocimiento y lo socializan de tal forma que se conozcan los objetos del mundo intersubjetivo o, por lo menos, que sean "conocibles".

Dicho mundo intersubjetivo es central en el contexto intercultural, desde que se caracteriza por la presuposición de un objeto o conocimiento durante la socialización es diferente o significa algo distinto para el yo y el otro. En el diálogo intercultural el sentido común logra superar las "diferencias en las perspectivas individuales que resultan de esos factores mediante dos idealizaciones básicas: la intercambiabilidad de los puntos de vista y la idealización de la congruencia del sistema de significatividades" (Schütz, 2005, p. 42). Sin embargo, en algunos contextos interculturales el sentido común se ve limitado por diferencias culturales más profundas, inclinándose a una resignificación que en muchos casos resulta en errores, lo que obstaculiza la comunicación.

En este campo, Ron y Suzanne Scollon conciben el contexto intercultural como un escenario en el que se establece un proceso comunicativo, pero que se diferencia de otros contextos comunicativos por la complejidad cultural que ahí se presenta; es decir, se habla de una comunicación interétnica, en la que se reconocen las diferencias culturales, por lo tanto, de identidades, ideologías, significados y símbolos. Asimismo, 
los Scollon también refieren a una comunicación del interdiscurso que alude a las diferencias comunicativas entre individuos dentro de un mismo ámbito, pero que son distintos por edad o género (Scollon \& Scollon, 2001, p. XII).

En el caso de esta obra, el interés se concentra en la comunicación interétnica como parte de la comunicación intercultural. Un gran ejemplo que los mencionados autores exponen es el de la comunicación entre un grupo étnico canadiense denominado atabasco y los canadienses mismos; el juicio de valor que destaca de estos encuentros por diferencias culturales, actitudinales y, en cierta forma, lingüísticas, es que los atabascos aparentan ser un grupo sumamente taciturno, pero no se consideran sus características culturales. De hecho, también tendría que tomarse en cuenta si la cultura de los canadienses frente a los atabascos no se distingue por ser demasiado talkative ("parlanchina").

Los Scollon señalan la importancia en el proceso comunicativo de no sólo considerar las características del otro, sino las propias, y tratar de comprender cómo éstas pueden violentar o afectar el proceso comunicativo a partir de la imagen y perspectiva que el otro tiene del yo. Por esta razón, ambos proponen una serie de acciones que deberían emprenderse en un contexto en el que se establece una comunicación intercultural (interétnica), que podrían sintetizarse de esta forma:

1. Comprender el impacto de la cultura sobre la comunicación.

2. Desarrollar la capacidad y la habilidad para percibir y considerar puntos de vista alternativos.

3. Desarrollar habilidades para realizar investigación en contextos interculturales y multiculturales. 
Estas propuestas de Ron y Suzanne Scollon en cuanto a la comunicación intercultural implican reconocer los factores sociales, culturales, históricos, políticos, ideológicos, entre otros, que intervienen. Es evidente que lo anterior es más marcado cuando en el contexto intercultural hay diferencias lingüísticas, esto es, lenguas diferentes. Es parte de lo que muchos agentes de pastoral han enfrentado a lo largo del tiempo y a lo que han intentado adaptarse, además de comprender los significados y modus vivendi de los pueblos indígenas con quienes trabajan.

Esto significa que, más allá de una temática lingüística, debe considerarse el aspecto comunicativo dentro de una dinámica decolonial, más que morfosintáctica como tal. El motivo es claro. Las barreras lingüístico-culturales en la labor de los agentes de pastoral llegan a ser tan grandes, que el remedio que se ha encontrado ha sido aprender la lengua de los indígenas. Es el caso del Instituto Lingüístico de Verano, organismo protestante que se ha caracterizado por su gran labor de adquisición de lenguas, traducción de la Biblia en diferentes lenguas indígenas en todo el planeta y de evangelización a través de estos medios, lo que ha hecho de los evangelistas o evangélicos un grupo religioso muy extendido en contextos indígenas y rurales de México y el mundo. Pero esta resolución de corte lingüística ha sido insuficiente.

En otros casos que trascienden la lengua, como el pentecostalismo de los toba en Argentina, con la Iglesia Evangélica Unida en la zona del Chaco argentino, se logró una comunicación, incluso síntesis religiosa, que se conjuga bien con el shamanismo de ellos, por lo que siendo pentecosteces pudieron transmitir algunos de los elementos culturales y adaptarse a las 
nuevas circunstancias históricas, sin que se trate de sincretismo per se, pero sí una suerte de hibridación (Ceriani \& Citro, 2005). Lo que destaca de este ejemplo similar al de la pastoral indígena y que quizá podría denominarse también teología india o teología de la inculturación, ${ }^{35}$ es que la práctica pastoral y de evangelización se ejercía con una plena conciencia cultural y de involucramiento en los problemas de la comunidad, respetando su forma de ver el mundo.

La tendencia en la actualidad en la labor pastoral de las misiones católicas es ir comprendiendo a los pueblos indígenas no únicamente con el aprendizaje de su lengua, sino tratando de entender sus lógicas y su visión del mundo, pues la lengua como tal no es suficiente, ya que ésta es una cuestión descriptiva y gramatical, en palabras Michael Agar (2002, p. 15): “enséñale a la gente gramática, dales un diccionario y ellos se comunicarán”. Pero Agar advierte que hay algo fuera de esa área gramatical que debe asimilarse y que incluye problemas como "quién eres, con quién estás tratando, el tipo de situación en la que estás, cómo trabaja la vida, y, lo que es más importante aquí, los significados que vinculan la lengua dentro del círculo, la gramática y el diccionario al mundo exterior" (Agar, 2002, p. 16).

En México, por ejemplo, en el estado de Chiapas es claro que los jesuitas, dominicos, diocesanos y maristas han intentado aprender las lenguas de los grupos con los que trabajan. De la

\footnotetext{
35 Se alude a este ejemplo como algo que podría concebirse a manera de teología india cristiana, porque no es exclusiva de la Iglesia católica. En muchos encuentros de teología india en Chiapas, Guatemala o Bolivia, en un ambiente ecuménico hay católicos, evangelistas y líderes-sacerdotes indígenas que expresan sus creencias.
} 
misma forma en que los misioneros laicos que se han integrado a las misiones han intentado hacerlo, pero destaca el día de hoy la postura de que no es suficiente aprender tojolab'al o ch'ol, también el contexto en el que puede sostenerse una comunicación horizontal con estos pueblos, en la que no sea el religioso o el agente de pastoral el que imponga, sino que se tenga una comunicación negociada. Por ello, la interculturalidad es central, pues contempla una naturaleza sociocultural que resuelve algo más que lo meramente gramatical.

Habermas se refiere al respecto con los llamados speech acts o actos de habla que se enfocan en el análisis de las acciones lingüísticas. Aquí, el filósofo alemán dice que las pretensiones de validez, que son la verdad, la rectitud y la veracidad, consisten en:

[...] una teoría de la comunicación elaborada en términos de pragmática formal [...] podrá utilizarse para una sociología de la acción si se logra mostrar de qué forma los actos comunicativos, es decir, los actos de habla, o las manifestaciones no verbales equivalentes, cumplen la función de coordinar la acción contribuyendo así a la estructuración de las interacciones (Habermas, 2014, p. 323).

En este mismo sentido, Habermas sostiene que "la acción comunicativa depende de contextos situacionales que a su vez son fragmentos del mundo de la vida de los participantes en la interacción" (Habermas, 2014, pp. 323-324). Estos fragmentos del mundo de la vida en medios interculturales del sur-sureste mexicano con agentes de pastoral y pueblos indígenas, dejando a un lado la diferencia de lenguas, se observan en las formas de organización, el entorno natural, el contexto y las características del 
encuentro social o los recursos materiales y lingüísticos con los que cada una de las partes interactuantes cuentan.

En la teoría de los actos de habla, sin ahondar en el tema, se asume que hay reglas que deben cumplirse para que la comunicación sea exitosa o afortunada. Aquí se habla de formas de conducta y principios conversacionales, a los que Grice (1975) llamó máximas cooperativas, y Leech (1990) principios o fórmulas de cortesía. En este orden de ideas, un acto de habla se logra si el interlocutor cumple con estos elementos, a saber, máximas conversacionales que contemplan la contribución "tal como es requerida, en el escenario en el que ésta ocurre, por la propuesta aceptada o la dirección del intercambio de habla en el que se está involucrado" (Grice, 1975, p. 45).

En el marco de una conversación, por ejemplo, los actores no pueden hablar más de lo que se requiere (máxima de cantidad), o lo que se habla debe ser relevante (máxima de relación), y así una serie de características más. De la misma manera debe pensarse en las fórmulas de cortesía que se expresan a través de las formas más adecuadas de preguntar, pedir o afirmar, lograr que haya una fluidez conversacional, hacer uso de elementos no verbales como la gestualidad, la proxémica, movimientos corporales, pausas en la conversación, back channels con su función de aquiescencia, titubeos y el silencio. Sin lo anterior, se asume que la conversación se perturba. El problema es que en contextos interculturales estos principios y máximas no aplican, pues hablamos de otras reglas socioculturales que predominan entre los grupos; es por lo que los Scollon hacen tanto énfasis en comprender los rasgos culturales, lingüísticos, sociales, contextuales, de cosmovisión, entre otros, pues gran parte del problema es que el análisis 
y la puesta en marcha de un proceso comunicativo en la interculturalidad se hace desde una perspectiva monocultural y anglo o eurocentrista.

En cierta forma, se deben localizar y proponer máximas conversacionales y fórmulas de cortesía interculturales. Es difícil pensar en que se pueda lograr con los programas de financiamiento mexicanos para el caso de los antropólogos y sociólogos, como lo hicieran Malinowski o Charles Briggs, de quien ya se hizo mención antes. Pero para los agentes de pastoral hay una gran oportunidad de llevarlo a cabo, dado el tiempo que permanecen en las comunidades y el contacto constante que sostienen con sus pobladores.

En la pastoral indígena actual, al considerar el diálogo como uno de los principales elementos de su praxis, es muy útil tener a la comunicación intercultural como una alternativa. Cierto es que no se involucran tanto en el terreno académico y no es común hallar misioneros que tengan una formación en estudios del lenguaje y la comunicación, sobre todo los agentes de pastoral laicos. Sin embargo, siguiendo una metodología educativa y de la pastoral misma, producto de los encuentros y juntas que organizan, incluso a nivel diócesis, tratan de buscar mejores mecanismos de comunicación, como aprender la lengua, pero también la comprensión de las formas de vida de los indígenas, yendo al lugar y permaneciendo un tiempo ahí para conocer sus costumbres y reflexionar sobre el papel que ahí ellos desempeñan como agentes de pastoral para preparar un terreno de comunicación intercultural, es decir, situarse en el contexto en el que están (Valtierra Zamudio, 2013). 
En la acción comunicativa en los entornos que aquí se abordan no debe pensarse en la intención de generar un dominio sobre el otro y viceversa; el propósito es otro y producto del paso del tiempo y del ideal de un diálogo intercultural. Desde la teoría de la interacción habermasiana, lo que implica la acción comunicativa como actos de habla y las fórmulas de cortesía:

[...] quedan insertos en un contexto de acción estratégica, bien sea porque éstos, como sucede con los imperativos, sólo vayan asociados a pretensiones de poder y, por lo tanto, no puedan generar por sí solos un vínculo ilocucionario, bien sea porque el hablante persiga con tales emisiones fines perlocucionarios (Habermas, 2014, p. 357).

Se trata, entonces, de un encuentro que pretende crear una influencia sobre el oponente orientada al éxito (perlocución), pero también se puede pensar en el establecimiento de relaciones interpersonales que se enfocan en el entendimiento de conformidad con las normas, en lo que Habermas define como acción regulada por normas (Habermas, 2014, p. 384). Sin embargo, hay aspectos que no están contemplados en esto que es el saber implícito, el hacer cotidiano que puede resolverse con una acción encaminada al entendimiento, es decir, que ilumina "ese trasfondo de saber implícito que penetra a tergo en los procesos cooperativos de interpretación" (Habermas, 2014, p. 385). Es lo que se denomina lebenswelt o mundo de la vida que "queda a espaldas de los participantes en la comunicación" (Habermas, 2014, p. 385), que es parte del saber del contexto que pueden compartir oyentes y hablantes en la interpretación de sus manifestaciones y que se 
relaciona más con la pragmática empírica, logrando una exitosa acción comunicativa.

Los principios establecidos por los Scollon que implican el desarrollo de una suerte de "ojo clínico" para entender expresiones, actos de habla, fórmulas de cortesía, manifestaciones comunicativas, entre otros aspectos, dentro de un contexto interétnico, comprender el contexto; es decir, el mundo de la vida es esencial para tener un panorama fuera del círculo que encierra el lenguaje.

Para conseguir esta meta se requieren, en principio, dos factores: la praxis y convivencia constante con la cultura del otro para pensarlo de forma distinta, y una capacidad teórico-analítica y de situarse (definirse en el contexto del otro), en lugar de sólo adaptarse.

En los dos apartados anteriores se ha tratado de exponer la importancia de dos ejes o modelos prácticos en la acción pastoral de hoy: la ecoteología y la comunicación. En ambos casos hay un entramado complejo de conceptos, estrategias y prácticas que convergen. La identidad, la alteridad, la interculturalidad, la noción de ecología que involucra lo político y lo social, por mencionar algunos, destacan la necesidad de discernir los fenómenos tan profundos que hay en la actividad pastoral en medios indígenas. El propósito de abordar los procesos comunicativos ahí es para dar cuenta de una preocupación operativa, pero también cultural y política, desde la Iglesia católica, con base en el Concilio Vaticano II y otros documentos, así como el desarrollo de un liberacionismo como fundamento de la praxis pastoral.

La comunicación intercultural que proponen los Scollon es clara en ámbitos donde se trata de llegar a acuerdos, es decir, 
en el de los negocios internacionales, pero también en aquellos momentos en que intentan converger culturas urbanas occidentalizadas y rurales indígenas es factible pensar en los procesos comunicativos para emprender acciones de liberación.

La liberación dentro del discurso religioso, aunque atemperada si se le compara con la de las décadas de 1960 y 1980, no sólo ha sufrido una transformación histórica por los procesos comunicativos, sino que a través de los estudios del lenguaje los agentes de pastoral han logrado desentrañar más las particularidades y problemáticas de los habitantes de las comunidades indígenas desde su experiencia y cosmovisión, por lo que se concibe vital la generación de espacios de diálogo.

A lo largo del texto se han visto las tendencias de reinterpretación, incluso sobreinterpretación, de la cosmovisión de los pueblos indígenas en lo religioso y cultural, razón por la que la comunicación intercultural ha sido fundamental en los paulatinos intercambios y diálogos para emprender acciones de liberación y de un aggiornamento continuo de la pastoral indígena.

Cuando se abordó el tema de la ecoteología, se exponía este proceso de cambio continuo del sentido de liberación, de las formas de llevarlo a cabo y de la necesidad de enfrentar el tema medioambiental sin una imposición de criterios, pensamientos y concepciones acerca de lo ecológico sobre los pueblos indígenas y sus culturas. Aclarado el punto y la importancia de la interculturalidad en la pastoral indígena, en esa dinámica de diálogo se contemplan más elementos y agentes de comunicación. El gobierno y los actores económicos en general son piezas clave para la liberación, pues a través de la conversación con estos vértices las sociedades indígenas pueden lograr un bienestar social 
sin depender de los programas asistencialistas que no resuelven la situación de vulnerabilidad en la que se encuentra la mayoría; es a través de estos mecanismos que pueden defender sus recursos naturales, encargarse de su protección y organizarse socialmente para romper con la condición de violencia y pobreza, entre otros aspectos.

En este esquema ideal diseñado a partir de la comunicación y la protección del entorno es donde se va redescubriendo lo que se conoce como gobernanza y el papel de la pastoral indígena por parte de la Iglesia católica y otras denominaciones cristianas - apoyadas por la sociedad civil, activistas, voluntarios, académicos, además de otros actores sociales esenciales- ha sido crucial para poder pensar en esto como un modelo angular que respeta la diferencia étnica, la identidad, la religión, el medio ambiente, la cultura, etcétera, engarzado en la pastoral indígena. Por eso podría empezar a hablarse de una pastoral en la gobernanza, tema que cierra este capítulo.

\section{La pastoral en la gobernanza}

La pastoral indígena hoy ha sufrido una serie de trasformaciones en su modus operandi. Aunque es utópico pensar que es posible alcanzar una inculturación, la encarnación del evangelio o fundar una Iglesia autóctona, este proceso ha incidido en modificar el pensamiento de buena parte de los miembros activos y comprometidos con la Iglesia de los pobres.

Es cierto que en varios de los círculos del organismo eclesiástico se asume un posicionamiento conservador que se opone a la 
praxis pastoral de izquierda, es decir, de la Iglesia de los pobres; además, es clara la tensión que se genera entre las altas jerarquías eclesiásticas y los pastorales y líderes adeptos al liberacionismo actual. Sin embargo, en América Latina es ya larga la trayectoria de un activismo eclesiástico que con la participación de laicos comprometidos y misioneros laicos se oponen a la ortodoxia eclesiástica y a los modelos económicos y políticos que aumentan el contraste entre ricos y pobres.

En este capítulo se ha hablado de gobernanza de forma general como concepto y su aplicación desde los organismos internacionales y nacionales, pero que se confina a una forma de construir políticas públicas frente a problemas, como un crecimiento desmedido de las ciudades que ocasiona inseguridad, deterioro del medio ambiente, baja calidad de vida, escasez de recursos, viabilidad, entre otros, y que rebasan las posibilidades de una autoridad municipal o estatal para solventar estos escollos. De esta forma, corresponde a los actores sociales (sociedad civil) colaborar de manera conjunta con las autoridades de gobierno para formular propuestas y llevarlas a cabo en beneficio de la población; dicho en otras palabras: desde esta dimensión, la gobernanza es una propuesta teórico-conceptual, pero también pragmática que pone a disposición:

[...] caminos y soluciones de orden institucional para organizar, acordar y hacer efectiva la acción concertada y colectiva que generan los imperativos del desarrollo y la urbanización, propiciando acuerdos verticales entre estamentos de gobierno y horizontales entre actores y gobiernos en diversos territorios (intermunicipalidad) 
y opciones para colaborar en red desde perspectivas relacionales (Iracheta, 2016, p.19).

En este ejemplo y explicación del término de gobernanza - que se concentra más en la gobernanza territorial- se observan aspectos muy específicos ya mencionados antes, como la insuficiencia de la acción y organización gubernamental en la resolución de problemas. ${ }^{36}$ Desde esta perspectiva, también se advierte la necesidad de que la sociedad civil se organizarse con las autoridades, partiendo del diálogo continuo y la exposición de problemas específicos o particulares de la población, de los que de otra forma es difícil que las autoridades tengan conocimiento, así como de lo que se necesita para lograr un bienestar social.

El objetivo de tocar esta temática de nuevo, tanto conceptualmente como con el ejemplo expuesto a través del desarrollo urbano, en relación con la acción pastoral es para mostrar que en el proceso de organizar a la sociedad civil hacia la resolución de problemas locales y específicos, la labor de los agentes de pastoral está totalmente involucrada. Cierto es que el liberacionismo como ideología que impulsa la pastoral en muchos contextos mexicanos no engloba la teoría y preceptos de los pioneros como Gustavo Gutiérrez, Jon Sobrino, Pablo Richard, entre otros, y esto lo corrobora la obra de algunos de esos primeros teólogos de la liberación que se fueron adaptando a los cambios del mundo,

\footnotetext{
36 Se hace referencia a la organización de los gobiernos en el sentido de la presencia de un sistema político tan dividido por sectores, que impide su coordinación conjunta para poner en marcha políticas que no sólo conciernen a una parte de la población o a un área específica, sino a toda una región y a todos los habitantes en general.
}

. 
sobre todo con el fin de la Guerra Fría, como François Houtart, Leonardo Boff, incluyendo personajes más pragmáticos que teóricos como Samuel Ruiz García, Arturo Lona Reyes, Leonidas Proaño, entre otros.

Hoy el mundo y América Latina vive circunstancias similares a la década de 1960, como la desigualdad, la exclusión y la marginación, pero en contextos políticos, económicos, culturales y sociales muy diferentes. Así, la pastoral en esta vocación liberacionista, en especial la pastoral indígena, además de centrarse en la liberación del oprimido y la opción por el pobre, también lo hace en el reconocimiento y asimilación o principios de inculturación de y en la diversidad de los pueblos indígenas, su cosmovisión y expresiones culturales.

En una época la revolución y el fusil simbolizaban la lucha por la libertad, ahora lo hace el diálogo (intercultural) y la expresión a favor del respeto a la naturaleza y la sostenibilidad. A lo que antes se enfocaba únicamente en una lucha agraria, ahora se agrega el factor de proteger los recursos naturales para sostén de la población, las futuras generaciones y el respeto de la máxima representación cultural y cultual de los pueblos originarios que, así como en Sudamérica se denomina Pachamama y que ha sido expandido o exportado por todo el mundo, en Chiapas y Oaxaca se reconoce como la madre Tierra, incluso en un afán inclusivo, "papá-mamá Dios".

Es importante la cuestión ecológica, porque es el principal recurso que los pueblos indígenas, en los que se concentra esta obra, tienen para sostenerse y se pretende que dependan únicamente de ese entorno natural como una opción real para acabar con su precariedad, pues entre los grandes males que 
han sufrido está la presencia de las transnacionales que introducen sus productos procesados que generan dependencia en la población, pese al costo, además de los programas gubernamentales que palian la escasez de forma momentánea, pero no resuelven de raíz el problema del hambre, la desnutrición, la salud, entre otros.

La apuesta de líderes indígenas reflejada en datos etnográficos de Chiapas y Guatemala entre 2007 y 2011, va desde modificar hábitos de consumo, respetar a la madre Tierra, evidenciar y exigir justicia ante la exclusión y la violación a sus derechos humanos, detener la violencia que ha llegado con la presencia del crimen organizado, así como exigir el respeto a su entorno para evitar que empresas transnacionales se apropien de sus manantiales, acaparen la tierra para la explotación de minas o usen su entorno como basureros industriales.

La tarea de las misiones a través de sus agentes de pastoral es dialogar con líderes (catequistas, alcaldes, el consejo de ancianos) y la gente en general sobre asuntos que afectan a la comunidad. En el curso de catequistas en Rizo de Oro, Chiapas, que ya se citó en este libro, en uno de los temas que desarrollaron ahí se mencionó el problema de los basureros industriales autorizados por el gobierno de Vicente Fox Quezada. Otro caso es cuando durante el sexenio de Felipe Calderón se desató una violencia sin precedentes, lo que llevó a muchas organizaciones eclesiásticas a denunciar los abusos y las condiciones en las que vivían las víctimas, sobre todo los migrantes y los campesinos, que eran amenazados para que trabajaran con los carteles en el cultivo de marihuana. En la zona kanjobal y hacia Marqués de Comillas, Chiapas, algunos religiosos maristas de la Misión de San José 
hablaban del peligro que había en la zona, donde se cultivaban estas plantas para su procesamiento y distribución.

En cualquier caso, el quehacer de la pastoral indígena en esta dinámica de respeto a la diferencia étnica y de mantener un diálogo horizontal con la población, promover acciones de educación integral, de cuidado ecológico, de formas alternativas en materia de salud, de romper con la dependencia hacia programas gubernamentales y destruir los hábitos de consumo que afectan a la población en su economía y salud, de promover una cultura de la denuncia, organizar talleres de género, entre otras actividades, implica una organización de la propia sociedad civil y de estos pastorales como voluntarios que forman parte de esos círculos de la sociedad, no para contraponerse a las autoridades y romper con el Estado, sino para colaborar en resarcir la insuficiencia de la acción gubernamental para el bienestar social de los pueblos indígenas y campesinos, así como expresar de forma pacífica su resistencia a acciones que sean perjudiciales para su cultura, su modus vivendi y su entorno.

En respuesta a lo anterior, el Estado ha turnado propuestas y recursos a sus organismos como el INALI, Sedesol, el INPI, entre otros, pero que son insuficientes para hacer visibles a estos pueblos y sus necesidades, o para resolver el problema de fondo, que es tan complejo como tratar de erradicar lo que el papa Francisco denomina como cultura del descarte. Aquí la labor de esta pastoral indígena se aleja de las formas doctrinarias de "llevar la palabra de Dios", de acompañar y consolar a los pueblos indígenas con consignas como "resiste" o "Dios prefiere a los pobres y a los que sufren"; incluso hay grandes avances en modificar 
la actitud de representarlos y decir a la población qué es lo que deben hacer para cambiar su situación.

Es claro que la participación de activistas de distintas ONG en colaboración con las misiones, la participación de académicos, así como organismos internacionales y nacionales que se han coordinado, han beneficiado a muchos pueblos indígenas y campesinos, ya sea con proyectos que tienen un impacto social directo -en cuanto a introducir tecnología amigable con el medio ambiente, asesoría legal, educación, programas de salud, entre otros- o como asesores, vínculos y árbitros en el momento de entablar un diálogo con las autoridades estatales, gestionar recursos de fondos gubernamentales de otros Estados como la Generalitat de Catalunya, Noruega o la Unión Europea, por mencionar algunos.

De esta forma, aunque no esté presente de forma académica, escrita o discursiva, cuando se habla de acción pastoral -y en específico de pastoral indígena- sí se observa con cierta claridad que después de los esfuerzos a través de la comunicación intercultural, de pensar al otro de forma diferente, de los esfuerzos de situarse en el otro y el propósito de optar por el pobre y liberar al oprimido, pero sobre todo de la participación activa y la visibilidad de la voz de la población indígena en tanto una forma de sociedad civil, está presente en el contexto en el que se da la gobernanza.

Se habla de gobernanza en relación con la pastoral indígena porque es hasta este momento en que se percibe una tendencia en muchos grupos de misioneros en colaboración con otros activistas de brindar un acompañamiento de diálogo y de interculturalidad. No es factible pensar esta dinámica en el año 2000 o antes, así como tampoco se puede aseverar que todos los que siguen la 
pastoral indígena presentan estas características de horizontalidad y dialogicidad de facto. La prueba se encuentra en varios eventos o el criterio de algunos agentes de pastoral de reinterpretar e imponer algunas prácticas ajenas a la cultura de los pueblos que atienden en materia religiosa con la teología india cristiana, pero aún en esta área hay transformaciones interesantes entre los religiosos que defienden las creencias y formas de expresar la religiosidad de los pueblos indígenas. Ante esto, se considera que se abre un camino más en el estudio en contextos sociorreligiosos y teopolíticos que podría empezar por denominarse la pastoral indígena en la gobernanza. 


\section{CONCLUSIONES}

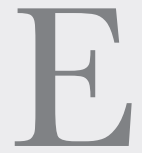

n la actualidad, la Iglesia católica, como muchas otras confesiones cristianas, han tratado de adaptar sus cánones y su modus operandi a las circunstancias que se viven en el mundo. Cierto es que las iglesias, incluyendo la católica, durante el siglo XX han enarbolado un discurso de no participar en la política y limitarse a aspectos espirituales, pero es claro que la religión y la política son esencialmente inseparables.

En el presente libro esto se ha hecho manifiesto cuando se habla de la Iglesia social y la Rerum Novarum de León XIII y, sobre todo, con la acción de los sacerdotes, religiosos y laicos involucrados en los problemas políticos y económicos del mundo desde finales de la década de 1960 hasta la fecha, pasando por diferentes etapas: una en la que influyó la oleada revolucionaria latinoamericana que se gestaba desde la década de 1950, sobre todo la Revolución cubana; otra en la que se buscaba establecer un diálogo con las culturas y que se intersecó con el objetivo (revolucionario) de la opción por el pobre y liberación del oprimido, y otra más enfocada en propiciar un diálogo intercultural más que ecuménico, en donde se presentan la pastoral y teologías alternativas, como la teología india cristina y la teología de la inculturación.

Es clara la tensión entre los sectores más ortodoxos y la oposición liberacionista que se ve en las décadas 1960-1990 y aún el día de hoy; un ejemplo son los efectos que muchas de 
las declaraciones del papa Francisco, que sin concebirse radical, causan en muchos sectores de la Iglesia y la población más conservadora.

En el presente siglo, la mayor parte de los acontecimientos problemáticos han dejado de tener carácter local y nacional para volverse globales, por lo que el Estado no es suficiente para resolverlos. En la idea de analizar la realidad y buscar soluciones a estos problemas, como la devastación ecológica, la trata de personas, la explotación laboral, la discriminación por cuestiones de género y preferencias sexuales, el trabajo infantil, la migración y otros fenómenos que se vinculan con la violación a los derechos humanos, la sociedad civil y otros grupos organizados, como los agentes de pastoral a través de las misiones y Comunidades Eclesiales de Base, se han interesado de forma paulatina en la creación de alternativas y caminos que guíen hacia un bienestar generalizado en el mundo para menguar la desigualdad creciente y la impunidad que se vive hasta hoy.

Gran parte de las opciones propuestas por estos grupos religiosos y civiles se enfocan en modelos inspirados desde una posición de izquierda, como el ecosocialismo, las epistemologías del sur o la ecoteología (esta última abordada páginas antes), que no sólo se concentra en la cuestión del medio ambiente, sino que toma en cuenta a la sociedad, su nivel de vida y la búsqueda de una organización de la gente para que con su voz se haga visible, se respeten sus derechos étnico-culturales, sus garantías individuales y su entorno ecológico, del que dependen material y culturalmente.

Como puede observarse, dentro de estas agrupaciones los agentes de pastoral y su labor planeada y llevada a cabo desde la 
diócesis y a través de las parroquias y misiones en contextos indígenas, ya no se concentra en una tarea meramente catequética. De hecho, este objetivo se fue abandonando poco a poco desde la influencia del liberacionismo, pues se veía la necesidad de acompañar y apoyar en áreas urgentes para lograr un bienestar social, mediante la autosuficiencia, por lo que se organizaban talleres de carpintería, talabartería y cursos para alfabetizar dentro de un espacio que se conocía como cursos de catequistas. ${ }^{37}$ También la fundación de sociedades cooperativas en el sur de México para la autosuficiencia y romper con la desigual e injusta relación que había entre los productores y acaparadores, fue parte de los resultados de una pastoral que ya no se enfocaba en catequizar o por lo menos no en su totalidad.

En la actualidad se discute sobre el cambio climático, acerca de la necesidad de cuidar y aprovechar el entorno natural y asegurarlo para las futuras generaciones (sostenibilidad), sobre alternativas que favorezcan a los migrantes en su derecho a buscar mejores condiciones de vida, a denunciar los abusos de autoridad o las vejaciones perpetradas por el crimen organizado, entre otros aspectos. El ejercicio pastoral que se involucra con estas situaciones se distingue por la conciencia de la realidad y crítica hacia instancias como el Estado y las grandes empresas transnacionales, pero no para declararles la guerra. Más allá de tomar medidas que generen violencia o enfrentamientos con el Estado, la acción pastoral en estos contextos pugna por un

\footnotetext{
37 De esa forma, la instrucción a catequistas que servía para paliar la escasez sacerdotal y llevar la misión de la diócesis a los lugares más recónditos del estado, se complementaba con conocimientos prácticos que serían útiles para la vida cotidiana de las comunidades.

$\sim \sim \sim \sim \sim \sim \sim \sim \sim \sim \sim \sim \sim \sim n$
} 
diálogo continuo con la gente, con el apoyo de ONG, para organizarse y entablar un diálogo constante con estos actores: Estado y agentes económicos.

El gran reto que entraña crear estos espacios de diálogo tiene que ver con la cultura, y la pastoral indígena ha hecho un gran esfuerzo a través de décadas de trabajo y comunicación, al comprender sus preocupaciones, creencias, necesidades, forma de ver el mundo y vivirla. Así, la Iglesia católica -y otras instancias religiosas también- ha podido ir construyendo un escenario intercultural y forjando un papel de arbitraje en el posible encuentro de los participantes de la conversación, pero también construyendo dentro de esa dinámica intercultural un escenario de gobernanza.

En ese sentido, los agentes de pastoral y la Iglesia no fungen sólo como un organismo estatal o empresarial, como se ha dispuesto entender la naturaleza del catolicismo, sino como parte de los colaboradores de la sociedad civil que luchan en pos de sus derechos y la defensa de su entorno natural. Al respecto, es importante señalar otras experiencias con sociedades indígenas en relación con la gobernanza, como el caso de los aguaruna del Alto Marañón amazónico, que en busca del modelo más adecuado de gobierno y representación local, se identificaron con el autoabastecimiento y la producción de tipo comunitario cooperativo, lo que se contraponía a las lógicas y políticas estatales; además de su reconocimiento como campesinos y sociedades indígenas desde estas perspectivas (Larsen, 2015), a diferencia de las políticas de inclusión y el multiculturalismo que ha sido duramente cuestionado por su vínculo con los modelos y la política neoliberal (Hale, 2002). 
La acción pastoral, en especial la pastoral indígena, sigue un proceso no sólo de discernimiento de las culturas-otras, sino de luchar por el reconocimiento y respeto hacia las formas de vida de las sociedades indígenas, más allá de la religión; es decir, sus esquemas de organización, sus mecanismos económicos, sus rasgos culturales, entre otros.

Como se puede advertir, la naturaleza del actor religioso es compleja y no se constriñe a los temas estrictamente catequéticos. La gobernanza y el escenario en el que se desenvuelve -constituidos, por lo general, por los tres actores clave que intentan entrar en diálogo (gobierno, actores económicos y sociedad civil)en apariencia no deja espacio para insertar ahí a los agentes religiosos.

La Iglesia católica, a diferencia de otros organismos religiosos, en la actualidad está considerada como un Estado; en otros sectores se le asume como una empresa, por su estructura organizativa y por algunas actividades lucrativas, en otro sentido se puede ver como una amplia red de organismos no gubernamentales.

Los agentes de pastoral de los que se ha hablado a lo largo de este trabajo, sin embargo, no sólo son religiosos y sacerdotes, sino también seglares y laicos comprometidos con la misión de la Iglesia de los pobres; ellos también entran en el escenario de diálogo y acompañamiento. La compleja estructura e imagen de la Iglesia en un contexto o entramado de gobernanza podría graficarse de la siguiente forma: 
Figura 3. Escenario de gobernanza en el contexto de la pastoral indígena $^{38}$

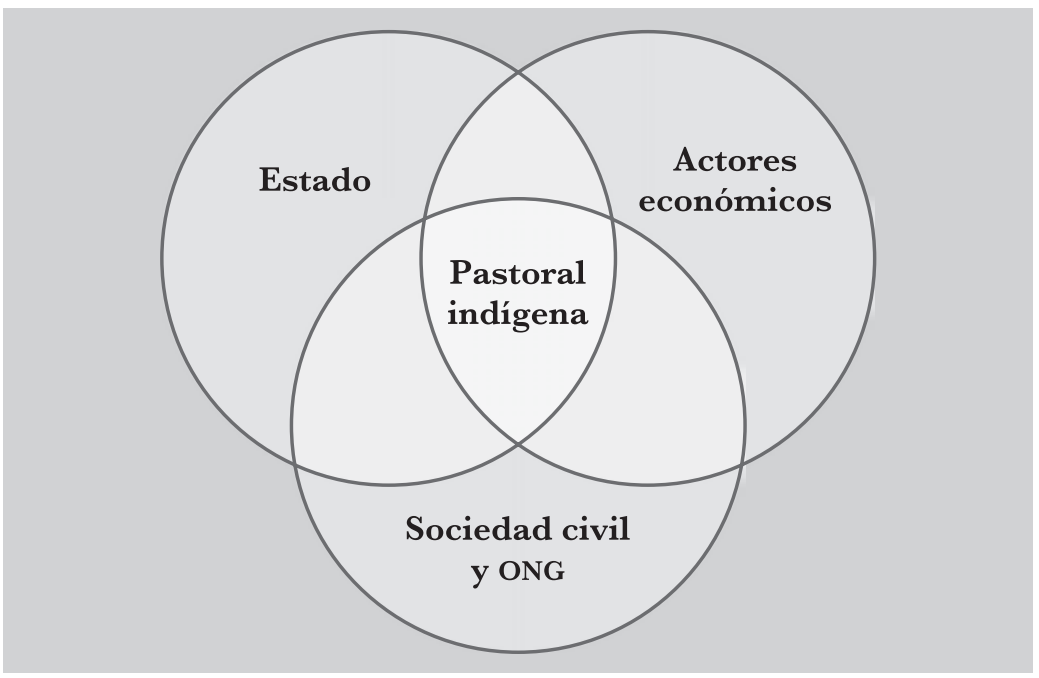

Fuente: elaboración propia.

Así, la pastoral indígena que engloba actores religiosos y laicos forma parte de una estructura gubernamental, económica y civil; consiste en una mezcla de agentes, pero en la praxis puede concebirse como sociedad civil, situación que ya se aclaró a partir de su definición propuesta por Hernández Legorreta (2018). Esto significa que no se puede afirmar que existe una sola práctica pastoral, en otras palabras, en la definición más general y ortodoxa de pastoral como un asesoramiento y acompañamiento espiritual

38 Esquema en el que se plasma la estructura de la Iglesia y su papel en el contexto de la gobernanza, a partir de la intersección de tres características de actores de la gobernanza que se concentra o recae en la figura de la acción pastoral. 
proporcionado por líderes religiosos, capellanes, ministros, entre otros. La pastoral indígena, la pastoral de la tierra, la pastoral de la movilidad y otras tantas de las que se escuchan el día de hoy rompen con ese esquema y se ubican más en un escenario y compromiso de lucha en lo catequético, pues el mensaje cristiano, se asume, está en acompañar al desfavorecido.

La Iglesia de los pobres hace suyos los problemas terrenales y busca colaborar en su resolución, como se ha visto en los casos expuestos en diferentes momentos de Oaxaca y Chiapas. Los cambios de estafeta de una actitud revolucionaria más inspirada en la teología de la liberación de los años sesenta y setenta, a una más dialógica es lo que me ha permitido pensar en posibilidades que están en construcción y que deben seguir debatiéndose, como una pastoral que si bien es militante, liberacionista e intercultural, también es una que surge en un contexto de gobernanza.

La pastoral indígena que asume los principios fundamentales de una Iglesia que libera y que es construida por la comunidad, también se involucra y preocupa por lo que afecta a la comunidad. Ante la marginación, la destrucción del entorno, la violencia, el despojo de tierras, la exclusión y muchos otros aspectos que constituyen una violación a los derechos fundamentales de estos pueblos indígenas y campesinos, desde la acción pastoral se generan los espacios para hacer visibles esas problemáticas y para crear conciencia en los círculos de poder, donde destacan las autoridades locales y nacionales, empresarios agrícolas o de corporaciones transnacionales y multinacionales.

Esta pastoral menos doctrinaria y más comprometida con la "realidad" y que busca establecer un diálogo con otros actores surge en la gobernanza, lo que significa que no es una pastoral 
que propicia un escenario de gobernanza, sino que desde éste se pone en marcha. Frente a la crisis del Estado y la crisis global, la gobernanza es una de tantas propuestas alternativas que obedecen y se adaptan al contexto actual. En estos sectores la Iglesia católica tiene experiencia de acomodarse, lo que podría pensarse como la posible generación de una pastoral del siglo XXI o, específicamente, una pastoral indígena del siglo XXI como una pastoral de la gobernanza. 
REFERENCIAS

II Conferencia General del Episcopado Latinoamericano 1968. (2004). Medellín. La Iglesia actual transformación de América Latina a la luz del Concilio Vaticano II. México: Dabar.

V Conferencia General del Episcopado Latinoamericano y el Garibe 2007. (2008). Aparecida. Documento conclusivo. México: Conferencia del Episcopado Mexicano.

AciPrensa. (2013). Discurso del Papa Francisco en encuentro con jóvenes argentinos. Recuperado de https://www.aciprensa.com/noticias/texto-completo-discurso-del-papa-francisco-en-encuentro-con-jovenes-argentinos88631

Agar, M. (2002). Language Shock. Understanding the Culture of Conversation. Nueva York: Perennial.

Aguilar, F. L. (2014). La Nueva gobernanza pública. Cátedra Magistral: La gobernanza de los Asuntos Públicos. Recuperado de http://ut.suagm.edu/ sites/default/files/uploads/Centro-Gobernanza/CATEDRAL_ ANUAL/La-Nueva-Gobernanza-Publica.PR.UT.pdf

Aguilar, F. L. (2015). La nueva gobernanza pública. México: Instituto de Investigación de Políticas Públicas. Recuperado de http://www.cesjal. org/MDPP/Gobernanza\%202015.pdf

Aguirre Beltrán, G. (1992). El proceso de aculturación y el cambio sociocultural en México. México: Universidad Veracruzana-Gobierno del Estado de Veracruz-Fondo de Cultura Económica.

Ameigeiras, A. R. (2012). El abordaje en la investigación social. En I. Vaselachis de Gialdino (coord.), Estrategias de investigación cualitativa (pp. 107-149). Buenos Aires: Gedisa. 
Argüello, A. (1979). Presentación. Fe cristiana y revolución sandinista en Nicaragua. Apuntes para el estudio de la realidad, 3, 5-7.

Arias Montes, M. \& Carrasco, B. (1998). Y la palabra de Dios se hizo indio. Teología y práctica de una catequesis inculturada y liberadora. Una propuesta desde Oaxaca-México. México: Dabar.

Bajtín, M. (2003). Estética de la creación verbal. México: Siglo XXI.

Barabas, A. (2015). Impactos de la práctica de la teología india entre los mazatecos de Oaxaca. ILHA, Revista de Antropología, 17(1), 5-31.

Bastian, J. (2011). La mutación religiosa en América Latina. México: Fondo de Cultura Económica.

Bedolla Villaseñor, P. (2017). La teología de la liberación: pastoral y violencia revolucionaria. Latinoamérica, 64(1), 185-221.

Berend, I. (2013). Europa desde 1980. México: Fondo de Cultura Económica.

Berryman, P. (2014). Teología de la liberación. México: Siglo XXI.

Biblia Latinoamericana. (2005). Madrid: San Pablo/Editorial Verbo Divino.

Blancarte, R. (2012). El pensamiento social de los católicos mexicanos. México: Fondo de Cultura Económica.

Boff, L. (1979). Eclesiogénesis. Las comunidades de base reinventan la Iglesia. Santander: Sal Terrae.

Boff, L. (2000). La dignidad de la Tierra. Ecología, mundialización, espiritualidad: la emergencia de un nuevo paradigma. Madrid: Trotta.

Bonfil Batalla, G. (2005). México profundo. Una civilización negada. México: Debolsillo.

Bourguignon, F. (2017). La globalización de la desigualdad. México: Fondo de Cultura Económica. 
Briggs, Ch. (2003). Learning How to ask. A Sociolinguistic Appraisal of the Role of the Interview in Social Science Research. Estados Unidos: Cambridge University Press.

Caravias, J. L. \& Barros, M. (1990). Teología de la Tierra. Los problemas de la tierra vistos desde la fe. Cuenca, Ecuador: El Espíritu Santo.

Geriani Gernadas, G. \& Citro, S. (2005). El movimiento del evangelio entre los toba del Chaco argentino. Una revisión histórica y etnográfica. En B. Guerrero Jiménez (ed.), De indio a Hermano. Pentecostalismo indígena en América Latina (pp. 111-170). Iquique, Chile: Ediciones El Jote Errante-Campus Universidad Arturo Prat.

Concilio Vaticano II (s/f). Gaudium et Spes. En Documentos Completos del Concilio Vaticano II. México: Librería Parroquial de Clavería/Editorial Basilio Núñez.

Chupungco, A. (2005). Inculturación litúrgica. Sacramentales, religiosidad y catequesis. México: Obra Nacional de la Buena Prensa.

De Vos, J. (1997). El encuentro de los mayas de Chiapas con la teología de la liberación. Eslabones. Revista semestral de estudios regionales, 14, 88-101.

Documentos Completos del Concilio Vaticano II. (s/f). México: Librería Parroquial de Clavería/Editorial Basilio Núñez.

Domènech, A. (2004). El eclipse de la fraternidad. Una revisión republicana de la tradición socialista. Madrid: Akal.

Duranti, A. (2000). Antropología lingüística. Madrid: Cambridge University Press.

Dussel, E. (1995). Teología de la liberación. Un panorama de su desarrollo. México: Potrerillos Editores.

El Observador. (2015). Arturo Lona. Un obispo al lado de los pobres. El Observador de la actualidad. Recuperado de https://elobservadorenlinea.com/2015/05/arturo-lona-un-obispo-al-lado-de-los-pobres/ 
Esquit, E. (2004). Las rutas que nos ofrece el pasado y el presente: activismo político. Historia y pueblo maya. En D. Euraque, J. Gould \& Ch. Hale (eds.), Memorias del mestizaje. Cultura politica en Centroamérica de 1920 al presente (pp. 167-193). Ciudad de Guatemala, Guatemala: CIRMA.

Estrada Saavedra, M. (2004). Construyendo el reino de Dios en la Tierra: pastoral y catequesis en las Cañadas Tojolabales de la Selva Lacandona (1960-1980). Sociológica, 19(55), 199-242.

Fazio, G. (1994). Samuel Ruiz. El caminante. México: Espasa Calpe.

Fornet-Betancourt, R. (2001). Transformación intercultural de la filosofia. Bilbao: Descleé de Brouwer.

Fornet-Betancourt, R. (2005). De la inculturación a la interculturalidad. Recuperado de http://www.servicioskoinonia.org/relat/355.htm

Francisco. (2015). Laudato si'. Sobre el cuidado de la casa común. Recuperado de http://w2.vatican.va/content/francesco/es/encyclicals/documents/papa-francesco_20150524_enciclica-laudato-si.html

Garma, G. (1998). Afiliación religiosa en municipios indígenas de Chiapas según el censo de 1990. Revista Académica para el Estudio de las Religiones, (2), 189-216.

Garrard-Burnett, V. (2005). Protestantismo en el mundo maya contemporáneo. En M. Ruz \& C. Garma (eds.), Protestantismo en el mundo maya contemporáneo (pp. 49-64). México: UNAM-Centro de Estudios Mayas, Instituto de Investigaciones Filológicas-UAM Iztapalapa.

Gil Tébar, P. (1997). Recreando la Palabra. La teología india y la Pastoral Indígena: la Diócesis de San Cristóbal de Las Casas (Chiapas). En S. Rodríguez Becerra (coord.), Religión y cultura (pp. 395-402). España: Junta de Andalucía-Consejería de Cultura-Fundación Machado.

Gobierno de Costa Rica (2018). Costa Rica supera 98\% de generación eléctrica renovable por cuarto año consecutivo. Costa Rica: autor. Recuperado de https://presidencia.go.cr/comunicados/2018/10/costa-rica-supera-98-de-generacion-electrica-renovable-por-cuarto-ano-consecutivo/ 
González Gasanova, P. (2006). Sociología de la explotación. Buenos Aires: Colegio Latinoamericano de Ciencias Sociales.

Granados, L. (2016). En el espejo haitiano: los indios del Bajio y el colapso del orden colonial en América Latina. México: Era.

Grice, P. (1975). Logic and Conversation. En P. Cole \& J. Morgan (eds.), Syntax and Semantics (pp. 41-58). Nueva York: Academic Press.

Gruzinski, S. (2007). La colonización de lo imaginario: sociedades indígenas y occidentalización en el México español siglos XVI-XVIII. México: Fondo de Cultura Económica.

Guber, R. (2011). La etnografia. Método, campo y reflexividad. Buenos Aires: Siglo XXI.

Habermas, J. (2014). Teoría de la acción comunicativa. Madrid: Trotta.

Hale, Gh. (2002). Does multiculturalism menace?: Governance, cultural rights and the politics of identity in Guatemala. Fournal of Latin American Studies, 34, 485-524.

Hall, S. (2010). Sin garantías. Trayectorias y problemáticas en estudios culturales. Bogotá: Universidad Andina Simón Bolívar-Instituto de Estudios Sociales y Culturales Pensar-Pontificia Universidad Javeriana-Instituto de Estudios Peruanos-Ediciones Envión.

Harvey, N. (2001). La rebelión en Chiapas. La lucha por la tierra y la democracia. México: Era.

Hernández Legorreta, G. (2018). Organizaciones de la sociedad civil: su impacto en la construcción de la gobernanza. México: De La Salle ediciones.

Hernández Pico, J. (1980). Apuntes para una teología nicaragüense. Encuentro de teología 8-14 de septiembre de 1980. Managua, Nicaragua: Centro Valdivieso-Instituto Histórico Centroamericano.

Hobsbawm, E. (2014). Historia del siglo XX 1914-1991. Barcelona: Crítica.

Hobsbawm, E. \& Ranger, T. (1993) The Invention of Tradition. Gran Bretaña: Cambridge University Press. 
Iglesias y Minería. (2017). Una Iglesia que camina junto a los pueblos indígenas de San Cristóbal de Las Casas. Recuperado de https://iglesiasymineria. org/2017/05/23/una-iglesia-que-camina-junto-a-los-pueblos-indigenas-de-san-cristobal-de-las-casas/

Innerarity, D. (2013). La gobernanza global, de la soberanía a la responsabilidad. Revista CIDOB d'Afers Internacionals, 100, 11-23.

Iracheta, A. (2016). Metrópolis y gobernanza. Bases conceptuales y experiencias. México: Biblioteca Básica de las Metrópolis-Siglo XXI-Escuela de Administración Pública.

Jacorzynski, W. (2008). En la cueva de la locura. Aportación de Ludwig Wittgenstein a la antropología social. México: CIESAS.

Juan XXIII. (1963). Carta Encíclica Pacem in Terris. Sobre la paz entre todos los pueblos que ha de fundarse en la verdad, la justicia, el amor y la libertad. Recuperado de http://w2.vatican.va/content/john-xxiii/es/encyclicals/ documents/hf_j-xxiii_enc_11041963_pacem.html

Judt, T. (2014). Postguerra. Una historia de Europa desde 1945. México: Taurus.

Kooiman, J. \& Van Vliet, M. (1993). Governance and Public Management. En K. Eliasen \& J. Kooiman (comps.), Managing Public Organizations. Londres: Sage.

Kovic, G. (2005). Mayan Voices for Human Rights. Displaced Catholics in Highland Chiapas. Austin, Texas: University of Texas Press.

Kramer, M. (1999). Ideology and the Cold War. Review of International Studies, 25(4), 539-576.

Krotz, E. (2002). La otredad cultural entre utopía y ciencia: un estudio sobre el origen, el desarrollo y la reorientación de la antropología. México: UAM Iztapalapa-Fondo de Cultura Económica.

Larsen, P. B. (2015). Derechos indígenas, gobernanza ambiental y recursos en la Amazonía peruana. Hacia una antropología de la posfrontera. Lima: Instituto de Estudios Peruanos. 
Leech, G. (1990). Principles of Pragmatics. Londres: Longman.

Lehmann, D. (1998). Fundamentalism and Globalism. Third World Quarterly, 19(4), 607-634.

Lerma Rodríguez, E. (2019). Los otros creyentes. Territorio y teopraxis de la Iglesia liberadora en la Región Fronteriza de Chiapas. San Cristóbal de Las Casas, Chiapas: Centro de Investigaciones Multidisciplinarias sobre Chiapas y la Frontera Sur-UnAM.

Leyva Solano, X. (2002). Catequistas, misioneros y tradiciones en las Cañadas. En J. Viqueira \& M. H. Ruz (eds.), Chiapas: los rumbos de otra historia (pp. 375-405). México: CIESAS/UNAM-Centro de Estudios Mayas-Instituto de Investigaciones Filológicas.

López, E. (2006). Teologías indias en las Iglesias, temores y esperanzas. En A. Puente Lutteroth (comp.), Actores y dimensión religiosa en los movimientos sociales latinoamericanos 1960-1992 (pp. 69-63). México: Universidad Autónoma del Estado de Morelos-Miguel Ángel Porrúa.

L'Osservatore Romano. (2013). Una Iglesia pobre y para los pobres. L'Osservatore Romano. 17 de marzo de 2013. Recuperado de http://www. osservatoreromano.va/es/news/una-iglesia-pobre-y-para-los-pobres

Manzo, D. (2017). A 46 años de obispado, Lona Reyes mantiene viva la defensa de los pueblos indígenas. Istmopress. Recuperado de http:// www.istmopress.com.mx/istmo/a-46-anos-de-obispado-lona-reyesmantiene-viva-la-defensa-de-los-pueblos-indigenas/

Marroquín, E. (1999). La cruz mesiánica. Una aproximación al sincretismo católico indígena. México: Palabra Ediciones.

Martínez-Alier, J. (2009). El ecologismo de los pobres veinte años después: India, México y Perú. Rebelión. México: Centro de Investigaciones Interdisciplinarias en Ciencias y Humanidades-UNAM. Recuperado de https://www.ecoportal.net/temas-especiales/economia/el_ecologismo_de_los_pobres_veinte_anos_despues_india_mexico_y_peru/ 
Martínez, N. \& Espejel, I. (2015). La investigación de la gobernanza en México y su aplicabilidad ambiental. Economía, Sociedad y Territorio, $X V(47), 153-183$. Recuperado de http://www.scielo.org.mx/pdf/est/ v15n47/v15n47a7.pdf

Marzal, M. (1973). ¿Es posible una Iglesia indígena en Perú? América Indígena, XXXIII(1), 107-123.

Marzal, M. (1991). El rostro indio de Dios. Perú: Pontificia Universidad Católica del Perú.

Marzal, M. (2002). Tierra encantada. Tratado de antropología religiosa en América Latina. Madrid: Trotta-Pontificia Universidad Católica de Perú.

Masferrer, E. (1998). La configuración del campo religioso después de Acteal. Revista Académica para el Estudio de las Religiones, (2), 8-33.

Modevite. (2016). Pronunciamiento de Modevite, municipio de Tenejapa, Diócesis de San Cristóbal de Las Casas, Chiapas. México: autor. Recuperado de https://modevite.wordpress.com/category/noticias/comunicados/

Monedero, J. G. (2017). Política tras la derrota de la política: posdemocracia, pospolítica y populismo. En B. De Sousa Santos \& J. M. Mendes, Demodiversidad. Imaginar nuevas posibilidades democráticas (pp. 199-228). España: Akal.

Morales Bermúdez, J. (2005). Entre ásperos caminos llanos. La diócesis de San Cristóbal de Las Casas, 1950-1995. México: Juan Pablos-UCACHUICH-COGyTECH.

Morello, G. (2007). El Concilio Vaticano II y su impacto en América Latina: a 40 años de un cambio en los paradigmas en el catolicismo. Revista Mexicana de Ciencias Políticas y Sociales, XLIX(199), 81-104.

Mosqueda Tapia, E. (2011). La lógica del campo religioso católico: desigualdad y memoria en torno al diaconado permanente indígena en la diócesis de San Cristóbal de Las Casas, Chiapas (1960-2008) (Tesis doctoral). El Colegio de México, Ciudad de México. 
Murad, A., Mahecha Clavijo, G. \& Londoño, A. (2016). Ecoteología. Un mosaico. Bogotá: Pontificia Universidad Javeriana /San Pablo.

Natera Peral, A. (2005). Nuevas estructuras y redes de gobernanza. Revista Mexicana de Sociología, 67(4), 755-791.

Pablo VI. (1967). Carta Encíclica Populorum Progressio. Recuperado de http://w2.vatican.va/content/paul-vi/es/encyclicals/documents/ hf_p-vi_enc_26031967_populorum.html

Pío XI. (1926). Rerum Ecclesiae. Sobre la acción misionera. México: Misioneros de Guadalupe. Recuperado de http://www.mg.org.mx/pdf/PIO_ XI_1926_RERUM_ECGLESIAE_ENCICLICA.pdf

Pirenne, J. (1970). Historia Universal. Barcelona: Editorial Éxito.

Primera Declaración de Barbados. (1971). Recuperado de http://www. servindi.org/pdf/Dec_Barbados_1.pdf

Polin, M. \& Robertazzi, M. (2015). Etnografía y reflexividad en el marco de la psicología social comunitaria: desde el plan de investigación a la elaboración de la tesis. Anuario de investigaciones, XXII, 231-240.

Refugio, G. (2008). Teología india (mecanuscrito inédito). México.

Reichel-Dolmatof, G. (1972). El misionero ante las culturas indígenas. América Indígena, XXXII(4), pp. 1137-1149.

Restrepo, E. (2014). Stuart Hall desde el Sur: legados y apropiaciones. Buenos Aires: Asociación Sueca de Desarrollo Internacional-Colegio Latinoamericano de Ciencias Sociales-ediciones Envión.

Ricard, R. (2002). La conquista espiritual de México. Ensayo sobre el apostolado y los métodos misioneros de las órdenes mendicantes en la Nueva España de 15231524 a 1572. México: Fondo de Cultura Económica.

Richard, P. (1998). Crítica teológica a la globalización neoliberal. En N. Da Costa et al., Globalizar la esperanza. Reflexiones desde América Latina y el Caribe en la aurora del tercer milenio (pp. 49-59.). México: Dabar. 
Riggins, H. S. (1997). The Language of Politics of Exclusion (Others in Discourse). Estados Unidos: Sage Publications.

Ríos Figueroa, J. (2002). Siglo XX: muerte resurrección de la Iglesia católica en Chiapas: dos estudios históricos. México: UNAM, Programa de Investigaciones Multidisciplinarias sobre Mesoamérica y el Sureste.

Rosaldo, R. (1991). Cultura y verdad. Nueva propuesta de análisis social. México: Conaculta-Grijalbo.

Rosales Ortega, R. \& Brenner L. (2015). Geografia de la gobernanza. Dinámicas multiculturales de los procesos económicos-ambientales. México: UAM-Iztapalapa-Siglo XXI.

Ruiz García, S. (1999). Mi trabajo pastoral en la diócesis de San Cristóbal de Las Casas. Principios teológicos. México: Ediciones Paulinas.

Sánchez Sánchez, J. (2007). La Comunidad Eclesial de Base: una alternativa de comunión en un mundo globalizado. Revista Iberoamericana de Teología, 5(2007), 47-68.

Schütz, A. (1995). El problema de la realidad social. Argentina: Amorrortu Editores.

Scollon, R. \& Scollon, S. (2001). Intercultural Communication. Gran Bretaña: Blackwell Publications.

Seidler, J. (1986). Contested Accomodation: The Catholic Church as a Special Case of Social Change. Social Sources, 64(4), 847-874.

Shorter, A. (1988). Toward a theology of inculturation. Nueva York: Orbis Books, Maryknoll.

Suess, P. (1993). Inculturación. Caminos, metas, principios. En J. Bottasso (comp.), La Iglesia y los indios. ¿500 años de diálogo o de agresión? (pp. 155-182). España: Ediciones Abya-Yala.

Tahar Chaouch, M. (2007a). Mitos y realidades sociológicas de la teología de la liberación en América Latina. Estudios Sociológicos, XXV(73), 69-103. 
Tahar Ghaouch, M. (2007b). La teología de la liberación en América Latina: una relectura sociológica. Revista Mexicana de Sociología, 69(3), 247-456.

Tannen, D. (1986). That's Not What I Meant. How Conversational Style Makes or Breaks Your Relatins with Others. Nueva York: William Morrow and Company, Inc.

Tapuerca, J. (2002). A los diez años. Carta pastoral colectiva de los obispos de Guatemala "500 años sembrando el evangelio" (pp. 5-18). Cobán, Guatemala: Centro Ak'kutan.

Theije, M. \& Mariz, G. (2008). Localizing and Globalizing Processes in Brazilian Catholicism. Comparing Inculturation in Liberationist and Charismatic Catholic Gultures. Latina American Research Reviere, 43(1), 33-54.

Todorov, T. (1989). Nosotros y los otros. México: Siglo XXI.

Tomichá, R. (2013). Teologías de la liberación indígenas: balance y tareas pendientes. Horizonte. Mutirão de Revistas de Teologia Latinoa-americanas-Comunicaçao, 11(32), 1777-1800.

Torres-Rivas, E. (2013). Revoluciones sin cambios revolucionarios. Guatemala: $\mathrm{F}$ et $\mathrm{G}$ Editores.

Valentini, D. (2009). Ecología y medio ambiente. México: Obra Nacional de la Buena Prensa-CELAM-Misión Continental.

Valtierra Zamudio, J. (2009). “...Y el Verbo se hizo carne”. El proceso de la inculturación y el camino hacia la autoctonía de la diócesis de San Cristóbal de Las Casas (Tesis de maestría). Centro de Investigaciones y Estudios Superiores en Antropología Social, Ciudad de México.

Valtierra Zamudio, J. (2013). Del discurso crítico a la práctica para una investigación situada. Buenos Aires: Consejo Latinoamericano de Ciencias Sociales-Agencia Sueca de Desarrollo Internacional-Organización de Estados Iberoamericanos. 
Valtierra Zamudio, J. (2015). Medio ambiente, sostenibilidad y religión: elementos para una pastoral alternativa. Muuch Xiimbal, Caminemos Funtos. Revista de Investigación y Estudios Internacionales, 1, 7-41.

Valtierra Zamudio, J. (2018a). El rostro indígena de Dios: teología india y comunicación interreligiosa maya. En. J. Illicachi Guzñay, L. Garcés \& R. Ramos (coords.), Protestantismo y catolicismo indigena desde una perspectiva antropológica (pp. 245-277). Riobamba, Ecuador: Universidad Nacional Chimborazo.

Valtierra Zamudio, J. (2018b). Pastoral indígena y resistencia hacia la teología india cristiana en Chiapas, México. Sociedad y Religión, 49(XXVIII), 73-100.

Vargas, J. (2012). Javier Vargas en Misión de Guadalupe [archivo de video]. Recuperado de http://www.youtube.com/watch?v=FVqrSS118co\& feature $=$ relmfu

Vázquez Olivera, M. \& Campos Hernández, F. (2016). México ante el conflicto centroamericano. Testimonio de una época. México: Bonillas Artigas Editores-Centro de Investigaciones Sobre América Latina y el Caribe UNAM.

Wallerstein, I. (2011). Después del liberalismo. México: Centro de Investigaciones Interdisciplinarias en Ciencias y Humanidades-UNAM-Siglo XXI.

Wittgenstein, L. (2004). Investigaciones filosóficas. México: UNAM.

Zavala, M. \& Morales, A. (2019). AMLO se reúne con obispo Arturo Lona. El Universal. Recuperado de https://www.eluniversal.com. $\mathrm{mx} /$ nacion/sociedad/amlo-se-reune-con-obispo-arturo-lona 


\section{Otras fuentes}

Bernarda, entrevista, 23 de octubre de 2008.

Eduardo, comunicación personal, 2 de diciembre de 2008.

G. Torres (FMS), comunicación personal, 20 de noviembre de 2008.

G. Torres, (FMS), comunicación personal, 27 de noviembre de 2008.

Horacio Olivares, comunicación personal, 25 de noviembre de 2010.

Juan Carlos Robles, entrevista, 26 de octubre de 2008.

María de la Luz Alcázar, conversación personal, 24 de septiembre de 2010 .

Ramiro, comunicación personal, 25 de marzo de 2011.

Ramón Castillo Aguilar (Pbro.), entrevista, 2 de noviembre de 2008.

Ramón Castillo Aguilar (Pbro.), comunicación personal, 12 de noviembre de 2008.

Ricardo Falla, entrevista, 2 de noviembre de 2008, Santa María Chiquimula, Guatemala. 
La presente edición de La pastoral indígena del siglo XXI en el sur de México. Misioneros, sociedad civil y gobernanza se terminó de imprimir en diciembre de 2019. Cuidado editorial: Andrea López Monroy. Diseño y maquetación: Olga Karina de la Cruz Sánchez. El tiraje consta de 300 ejemplares. 


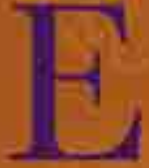

ste fibro es producto de una investigación que cl autor inicio ch su primer encuentro tanto bibliografico como ürsitu con el sur-sureste mexicano, desde 2007, y con Guatemala, en 2008. Los vinculos que tiompo arrás cstableció con la congregación de los Hermanos Maristas dela Ensenanza y el posterior eontacto que tuyo con otros agentes de pastor ral, colegas, macstros y catequistas indigenas lo llevo a tejer un escenario complejo derclaciones que tomó mucho tiempo discermit:

Ea pastoral indigena que englobatactores religiosos y laic os forma parte de una estructura gubernamental, cconomica y civil consiste en una mezcla de participantes, pero en la praxí puede concebirsc como sockedad civil. Esto significa que no se puede afimar que existe una sola practica pastoral, en la definicion mas general y ortodoxa de pastoral como unasesoramicnto y arompanamiento espiritual proporcionado por lidercs religiosos, capellanes, ministros; crure otros. Frente a la crisis del Estado y la crisis ylobal, la gobernanza esuna de tantas propuestas alternativas que obedecen y se adaptan al contexto actual. Fn estos sectores la Iglesia eabolica ticne experiencia de zcomodarsc, lo que podnia pensarse como la posible gencración de una pastoral del siglo Xxi o, cspecificamente. una pastorall indigena del siglo Xxxl como una pastorat de lajgobernamza.
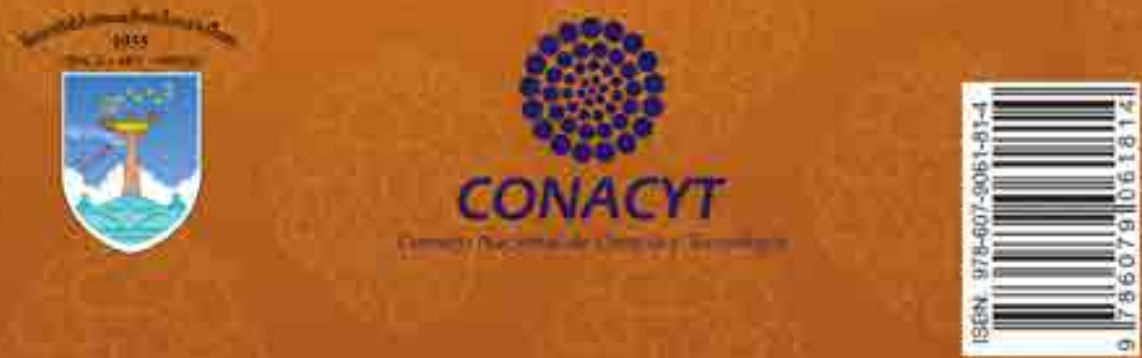